\title{
OVER DE BELEGERING VAN HET FORT JACATRA.
}

\author{
(22 DEC. 1618 - 1 FEBR. 1619). \\ DOOR
}

J. W. IJZERMAN.

(met Bijlagen).

In het vierde deel van "De opkomst van het Nederlandsch gezag in Oost-Indië» heeft Jhr. Mr. J. K. J. de Jonge op heldere wijze de lotgevallen van de Nederlandsche nederzetting te Jacatra geschilderd, haar ontstaan als eenvoudige koopmansloge, haar omzetting in een "volcomen" fort en haar vervanging door het bekende Kasteel van Batavia ${ }^{1}$. Zijn beschrijving wordt door tal van bescheiden, deels als bijlagen opgenomen, deels reeds vroeger bekend geworden, toegelicht en gestaafd. Onder die stukken komen twee in het Rijksarchief berustende dagregisters voor, beide tijdens de belegering gehouden, waarvan een in zijn geheel werd afgedrukt en het ander, behoudens een enkele korte aanhaling, ter zijde gelegd. «Ongelukkig», merkt De Jonge op, "zijn de schrijvers van beide journalen onbekend, en hunne namen heb ik niet kunnen opgeven., ${ }^{2}$

In de volgende bladzijden zal worden uiteengezet, op welke gronden voor schrijver van het door de De Jonge uitgegeven journaal mag worden gehouden de. onderkoopman MeLiS REMMERTS LANTS en voor schrijver van het nu voor het eerst gepubliceerde (als Bijlage I hierachter afgedrukte), de predikant adriaen Jacobsen Hulsebos.

1 Een zakelijke beschrijving van het voorgevallene in 1618 en 1619, waarbij vooral ook gebruik gemaakt is van Engelsche bronnen, geeft Tiele in de Bijdragen t. d. T. L. en V. van N.-I., 5 de $^{\text {e }}$ Volgreeks, 1887, Dl. II p. $207 \mathrm{vgg}$. De later bekend gemaakte stukken maken, zooals Tiele opmerkt, een herziene uitgaaf van Mr. J. A. van der Chijjs' monographie „De Nederlanders te Jacatra" Amsterdam 1860, wenschelijk.

${ }^{2}$ Noot op p. 138. 
Doch alvorens in eenige beschouwing van deze dagregisters te treden, moge een korte herinnering aan de hoofdmomenten van het beleg voorafgaan.

Den $23^{\text {sten }}$ December 1618 begonnen de vijandelijkheden tegen de Jacatranen en de Engelschen, op last van Coen en zijn Raad, met een krachtigen uitval der bezetting. In den nacht van 30 op 31 December begaf de landvoogd zich scheep, om de Engelsche vloot aan te tasten, maar overmacht dwong hem de wijk te nemen naar de Molukken om zijne verspreide strijdkrachten te verzamelen. Een garnizoen van 250 weerbare mannen, onder welke 25 Japanners en 70 "swerten" ' bleef onder Pieter van den Broecke achter. Met kracht werd aan de verbetering der weermiddelen gearbeid, maar aanvallen van den vijand bleven achterwege. Als gevolg van onderhandelingen kwam den $19^{\text {den }}$ Januari 1619 een overeenkomst met den Regent van Jacatra tot stand, waarbij tegen betaling van 6000 realen van achten de verklaring verkregen werd, dat de vroegere met Both en Reijnst gesloten contracten gehandhaafd zouden blijven en het fort tot de terugkomst van Coen in stand gehouden. Den $22^{\text {sten }}$ Januari begaf Van den Broecke zich naar het hof van den Regent van Jacatra, maar nauwlijks daar gekomen, werd hij met de zijnen verraderlijk gevangen genomen.

Ook nu waagden de belegeraars geen poging om zich door wapengeweld van het fort meester te maken. Maar zij verkregen den $31^{\text {sten }}$ Januari het sluiten van een nieuw contract, nu met den Engelschen Admiraal Dale en den Regent, inhoudende, onder meer dat de versterking den volgenden dag door de bezetting zou worden verlaten, en door de Engelschen in bezit genomen, terwijl het geld en de goederen aan den Jacatraan zouden komen.

Nu kwam echter de Rijksbestierder van Bantam tusschenbeide, en belette de uitvoering der bedongen maatregelen. Den $6^{\text {den }}$ Februari werd dan ook door die van het fort de overeenkomst van 31 Januari opgezegd, en reeds den $9^{\text {den }}$ daaraanvolgende een verdrag met Bantam aangegaan. Een vierde van alle goederen en de helft van het geschut zouden moeten worden achtergelaten door de bezetting, welke naar Bantam zou worden overgebracht

1 Deze "swerten" waren slaven. Zie hierover de Resolutie, genomen in het fort, den $17^{\text {den }}$ Januari 1619. Bijlage IX.

Dl. 73 . 
en daarbij gewaarborgd tegen "alle overlast en molestatie» van de Engelschen en anderen. Maar ook dit verdrag bleef een doode letter.

Eindelijk, den $27^{\text {sten }}$ Februari, schepten de verdedigers nieuwen moed en besloten zij "de plaetse in te houden, soo lange het Godt gelieven zal.» Deze krachtige houding had ten gevolge dat 11 Maart een "contract ende verbondt" met den Regent van Bantam werd gemaakt tegen de Engelschen. De wapenen zouden van beide zijden blijven rusten tot de aankomst van den Gouverneur, of van voldoende Nederlandsche schepen om de bezetting zonder gevaar voor vijandelijke aanvallen naar elders over te brengen.

Den volgenden dag werd het fort: «Batavia gedoopt.

Slechts eenmaal, den $9^{\text {den }}$ April, werd op den wapenstilstand inbreuk gemaakt, om door een uitval de vijandelijke batterijen te vernielen; maar sedert bleef de grewapende vrede voortduren.

Zoo was het fort, bij de aankomst der Nederlandsche scheepsmacht van Amboina op 28 Mei, als gevolg van den naijver tusschen Jacatranen, Bantammers en Engelschen, of zooals Coen het uitdrukt "alleen door sonderlinge genade ende schickinge Godes » behouden.

Nadat de versterkingen waren ontscheept en een deel der bezetting van het fort daarbij was ingedeeld, ' ${ }^{1}$ deed Coen den $30^{\text {sten }}$ Mei de stad Jacatra bestormen. In korten tijd was de zwakke tegenstand der Javanen gebroken, en kon hij aan de Heeren XVII schrijven, wij hebben « voet en dominie in 't landt van Java becomen., Gelegenheid tot het stichten van een vast rendez-vous was verkregen, en de grondslag was verzekerd van Batavia, de toekomstige Koningin van het Oosten.

Thans terugkeerende tot de dagregisters, zij in de eerste plaats aangeteekend, welken grond De Jonge voor de verschillende behandeling geeft. Op p. 138 zegt hij: * Het journaal, dat wij hier mededeelen, is het meest naauwkeurige, terwijl het andere,

1 Er was o. a. een compagnie bij de voorhoede onder Jacque Lefebre, aangevoerd door kapitein Jan Jansz van Gorkum, luitenant Abraham Strijker en vaandrig Hendrick Harmensz; bij een andere compagnie was ingedeeld Jacques Coetelij. Onder Coen, die de "bataille" commandeerde stonden o. a. luitenant Abraham van Uffelen en vaandrig Jan de Brasser. Zie de als Bijlage IV hierachter afgedrukte Resolutie, genomen 25 Mei 1619 in "de Trouw" omtrent Cheribon. 
waarvan wij slechts een kort gedeelte geven, meer het kenmerk draagt van later te zijn opgesteld». Beide redenen zijn voor bestrijding vatbaar; zeker kan uit het oogpunt van nauwkeurigheid het in zijn werk afgedrukte niet hooger worden gesteld dan het andere, en zonder twijfel berusten beide op dagelijks bijgehouden aanteekeningen.

Maar er is iets anders, dat volkomen verklaart, waarom het een aangenomen, en het ander verworpen werd. Het reeds gepubliceerde stuk loopt van 4 Januari tot 11 Mei 1619, van kort na Coen's vertrẹ bijna tot zijn terugkeer. Het is hoogst belangrijk door de teekenachtige bijzonderheden die het geeft en door het licht, dat het werpt op de bachanaliën, die gedurende de tweede periode van het beleg in de bedreigde versterking werden afgespeeld. Met vlijmende kritiek stelt de schrijver het onwaardig gedrag van zijne superieuren aan de kaak (p. 149) en brengt hij zijne persoonlijke minachting tot uitdrukking voor den "provisioneelen Commandeur" (Pieter van Raey p. 150), den "vaendrich, (Hendrick Harmensz p. 144) en den luitenant (Abraham Strijcker, Strycker of Stricker p. 150). Het ligt voor de hand, dat aan dit levendig geschreven dagverhaal, dat meer dan 4 maanden omvat, de voorkeur werd gegeven.

- Aantrekkelijk daarin is voor ons mede de waardeering van den vijand, wanneer daartoe een enkele maal aanleiding was. Toen 9 April een aanval werd gedaan door den luitenant en den vaandrig met 35 musketiers en eenige "swarten" op twee batterijen bij het huis van den Chinees Watting ${ }^{1}$, , bezuiden het fort op den rechteroever der rivier, stuitten zij op een troepje van 30 , slechts met lansen gewapende inlanders, aangevoerd door Kjai Aria of zooals de Hollanders hem noemden, den ouden graaf. De Jacatranen hielden stand; "ze stonden louter vast", en wilden eerst wijken, toen meer dan de helft gedood of gewond was. "Het hielt hard genoech, hadden de·Javanen mede roers ghehadt, het soude te beduchten gestaen hebben, dat ons volck die batteryen niet aen brant gecregen souden hebben (p. 154).

De dappere oude zelf had een schampschot in de borst en een in zijn kuit gekregen, het laatste bij het overzwemmen der rivier. Hier toonde hij, dat zijn bedreiging op 18 Januari 1619 van de Engelschen die onze afgezanten niet vrij naar het fort

1 Zie over den anachoda Watting het artikel over So Bing Kong, door B. Hoetink, op p. 348 van dit deel der "Bijdragen”. 
wilden laten terugkeeren, tot voor hen minder gewenschte gevolgen zou hebben geleid, indien zij niet hadden toegegeven.

Maar ook het tweede, het als Bijlage I aan dit opstel toegevoegde, dagregister is van belang, zoowel omdat daarin bijzonderheden worden aangetroffen, die elders niet worden gevonden, als om het gebruik, dat er van gemaakt is. Het manuscript is een copie, waarvan het begin met een andere hand is geschreven dan het slot. Het vermeldt op eenvoudige wijze alles wat tusschen 22 December 1618 en 1 Februari 1619 is voorgevallen.

Het maakt den indruk, bijgehouden te zijn door iemand van aanzien, een dergenen, die goed bekend was met alles wat er omging in het fort, en met de verschillende onderhandelingen, welke met de belegeraars gevoerd werden. Elke bladzijde getuigt daarvan.

Hier geen stekelige opmerkingen, geen beoordeeling van handelingen, alleen nuchtere vermelding van feiten. Het is alsof het manuscript komt uit de hand van hem, die officieel met de opteekening der dagelijksche gebeurtenissen was belast.

Onder de personen, die daarvoor in de eerste plaats in aanmerking komen, zijn er twee als het ware aangewezen: de predikant en de schoolmeester. De laatste zat niet in den Raad van het fort, de eerste daarentegen onafgebroken van het begin tot het einde van het beleg. De schoolmeester Jan van den Broecke bleef bescheiden op den achtergrond; de predikant trad voortdurend mede op den voorgrond. Hij was een bekwaam penvoerder. Dat hem, man des vredes, ook de zaken des oorlogs niet vreemd waren, blijkt onder meer uit zijn brieven en uit de uitvoerige verantwoording bij zijn verhoor. ${ }^{1}$

In het bijzonder ook uit het antwoord, dat Pieter van Raey, na de gevangenneming van Pieter van den Broecke, Commandeur van het fort, gaf op de vraag: "Wat gewelt dat er naert vertreck van den Generael Coen opt fort gedaen is, wat approches de vijanden gemaect hebben, hoe veel batterijen ende hoeveel gheschut tegen haer geplant is, hoe veel schooten den vijant dagelijckx gedaen heeft, wat bressen de vianden met schieten gemaect hebben ende wat stormen datter gedaen sijn ?» Dit luidde o. a.: *dat er achter het Chineesche kwartier 9, achter het Engelsche huis 6, en op den hoek in Paap Jan's batterij

1 Zie zijnn verantwoording Bül. V. 
11- stukken waren opgesteld»; en verder: «De schooten, die dagelijx gedaen sijn, gedraecht hem deposant aent fournael bij den predicant gehouden:.

$\mathrm{Er}$ is dus alle grond om aan te nemen, dat het manuscript Bijlage I een copie is van een gedeelte van het dagregister met welks bijhouden $D^{s}$ Adriaen Jacobsen Hulsebos belast was.

Het ligt mede voor de hand, dat de aanteekeningen van den predikant voor den bevelhebber van het fort, Pieter van den Broecke, na diens invrijheidstelling, beschikbaar zijn geweest.

Hulsebos' dagregister begint met een aanloop, behandelt dan het gebeurde op 22 en 23 December, geeft vervolgens een inwerp, een beschrijving der gesteldheid van het fort bij het begin van het beleg, en gaat verder geregeld voort.

$\mathrm{Nu}$ doet zich een merkwaardig geval voor.

In 1634 verscheen, zoowel te Haarlem als te Amsterdam een werk, getiteld: « Korte historiael ende journaelsche Aenteykeninghe, van al 't gheen merck-waerdich voorgevallen is, in de langhduerighe reysen, soo nae Cabo Verde, Angola, etc. als insonderheydt van Oost-Indien; beneffens de beschrijvingh en af-beeldingh van verscheyden steden op de Custe van Indien, Persien, Arabien en aen 't Roode Meyr: aldereerst (van wegen de Gheoctroyeerde Oost-Indische Compaignie) besocht, en opghedaen, door Pieter van den Broecke». Daarin handelen blz. 100-116 over het beleg van het Nederlandsche fort te Jacatra.

Legt men dit verhaal van Van den Broecke naast het dagregister van $D^{s}$ Hulsebos, dan valt het op dat het eerste van het begin tot het einde een uittreksel is uit het tweede. Dat uittreksel is zeer verkort, maar hezigt bij voortduring uitdrukkingen, welke in beteekenis niet van het origineel verschillen. Slechts wanneer enkele feiten, die op de persoon van Van den Broecke betrekking hebben, moeten worden aangeteekend, kan van eigen werk van dezen gesproken worden.

Deze opmerking gaf aanleiding tot een nader onderzoek van het uitgebreider reisverhaal van Van den Broecke, waarvan het handschrift naar Tiele's aanwijzing gevonden wordt in de Universiteitsbibliotheek te Leiden. ${ }^{1}$ De titel luidt: "Journael van

1 Zie: Mr J. E. Heeres: Pieter van den Broecke en zijne journalen (fragment) (In „Geschiedkundige Opstellen, uitgegeven ter eere van $\mathrm{D}^{\mathrm{r}} \mathrm{H}$. C. Rogge". Leiden 1902.) V. d. B. werd 25 Febr. 1585 te Antwerpen geboren en overleed 4 Dec. 1640 voor Malaka. (Verg. De Jonge IV, p. CV). De Gouver- 
mijn Voiagien gedaen naer Capbo Verde, van daer naer Guinea, voorts in Angola, ende daer naer in Oost-Indien onder het beleydt van den E. - $\mathrm{H}^{\mathrm{r}}$ Gouverneur Gen ${ }^{\mathrm{a}^{\prime}}$ Gerart Reijnst, begonnen de eerste mael in de maendt November in den Jaere 1605». Daarbij werd de verrassende ontdekking gedaan, dat dit grootere werk, waar het over het fort Jacatra handelt, voor verreweg het grootste deel een afschrift is van het door ons beschouwde dagregister. Hier en daar zijn kortere of langere stukken weggelaten, en natuurlijk weder enkele gedeelten om de bovengenoemde reden gewijzigd of ingevoegd, maar als geheel beschouwd, kan van een auteurschap van Van den Broecke niet worden gesproken. Hij heeft zich het werk van den opsteller van ons handschrift toegeëigend, zonder melding te maken van diens naam.

$\mathrm{Na}$ het bovenstaande behoeft het geen verwondering te wekken, dat hetgeen door Van den Broecke na 1 Februari 1619 wordt gemeld, bijzonder kort en van bijzonder weinig belang is. Wat reeds als uittreksel uit zijn uitgebreider "Journael, gedrukt is, bevat bovendien in het oog springende fouten. Zoo zou Coen 25 April uit de Molukken teruggekomen en den volgenden dag geland zijn, om den $30^{\text {sten }}$ d.a.v. Jacatra te nemen en na het raseeren van de stadsmuren en huizen, den $8^{\text {sten }}$ dier maand (sic) voor Bantam te verschijnen.

Deze dwaasheden worden in het Leidsche handschrift niet gevonden. $\mathrm{Ze}$ komen voor rekening van den vervaardiger van het uittreksel of wel van hem, die dit voor de pers gereed makkte. Om op dit punt Van den Broecke schoon te wasschen wordt hierachter ook het gedeelte van zijn manuscript afgedrukt, dat loopt van 2 Februari tot 30 Mei. $^{1}$

Een ding blijft echter voor zijn rekening en dat is de vergissing, waartoe zijn verhaal omtrent de afzetting van den Regent van Jacatra aanleiding heeft gegeven. Dat Camphuis ${ }^{2}$ en Van der Chijs ${ }^{3}$, hem volgende, het drama, waarbij dat hoofd met de kris op de borst bedreigd, zich aan den Bantamschen Toe-

neur van Twist liet zijn stoffelijk overschot met dat van Joan de Meer en den Predikant Schottanus in Juni 1642 opgraven, „ende met statelijoke eere gesamentlijok in een gemaeckte tombeau" stellen. (Dagh-Register Cast. Bat. 1642 , p. 163).

1 Zie Bijl. II.

2 Zie Joannes Camphuis, Het Koninkrijk Jakatra, door den $\mathrm{H}^{\mathrm{r}}$ G. G. Coen veroverd, enz., bij Valentijn, Oud en Nieuw Oost-Indiën, IV, p. 443.

$\checkmark$ De Nederlanders te Jacatra. 
menggoeng overgaf, in den avond van 2 Februari laten afspelen, ligt voor de hand; maar dat De Jonge IV, p. CX denzelfden datum aanneemt, is minder verklaarbaar. Èn Coen in zijn missive van 5 Augustus (p. 174), èn de schrijver van het dagregister van 4 Januari tot 5 Mei (p. 150) toch, doen omstandig het verhaal, dat deze gebeurtenis op 15 Februari plaats had. ${ }^{1}$

Met weemoed neemt Van der Chijs den $2^{\text {den }}$ Februari afscheid van Van den Broecke. "Hier», zoo zegt hij (noot p. 106) "verlaat ons één onzer hoofdbronnen, namelijk het journaal Van den Broeck, want de weinige regelen, welke in dit kostbare werk over de verdere geschiedenis van het beleg voorkomen, hebben zeer weinig te beduiden». De lofspraak gaat over het hoofd van Van den Broecke heen, en geldt den anonymen schrijver van ons dagregister, $D^{s}$ A. J. Hulsebos.

Van den Broecke's werk werd verscheidene malen herdrukt ${ }^{2}$, en door allen, die over de belegering van het fort Jacatra hebben geschreven, in ruime mate gebruikt. Zoo kreeg hij geheel onverdiend, naar aanleiding van zijn gedrag te Jacatra, den naam van een onverschrokken held, van een man van buitengewone doodsverachting, en kon hij bijna twee en een halve eeuw een der meest verheerlijkte figuren in 's lands historie blijven. ${ }^{3}$

De gewaande glorierijke daad wordt op zeer sobere wijze in het groote onuitgegeven "Journael, beschreven. Daar leest men: «Die vant fort booden 2000 realen van $8^{\text {en }}$ voor mijn ranson midts conditie, dat den Coninnck mij eerst int fort soude senden, daerin niet wilde verstaen; maer sondt mij gebonden op de pundt van de stadt recht tegenover de catt, om in sijnnen naem 't fort op te aijssen met de Engelssen; dan soo sijet datelijck niet overgeven wilden, wilden sij tsamen datelijck 't fort beschieten ende daer

1 Verg. Calendar of State Papers, East-Indies (1617-1621) p. 288: That King [of Bantam] conquers the King of Jacatra, and takes his kingdom from him, 15 Febr. 1619.

2 Zoo in Begin ende Voortgangh van de Ver. Ned. Geoctr. Oost-Ind. Comp. 1645; zoo voor J. Hartgers in 1618; zoo bij G. J. Saeghman (z. jr. omstr. 16601670); zoo in Leeuwarden 1717. Zie Tiele, Ned. Bibl. van Land- en Volkenkunde, 1884.

3 Nog in 1845 verscheen te Amsterdam een werkje van P. Weeda, Pieter Van den Broek in Azië of geschiedenis der togten en verrigtingen van dezen Nederlandschen Regulus, 
naer bestormen ende niemant bij den lijve laaten blijven. Ick, hun radende standvastich te blijven, gaven ten antwoord hun beraet tot sanderdach te nemmen».

Het uittreksel, de «Korte historiael ende journaelsche Aenteyckeninghe", heeft de zaak eenigszins opgesierd en met een paar woorden voor een inkleeding gezorgd, in overeenstemming met het heldhaftige van het bedrijf. Het zegt: *Den $29^{\text {sten }}$ ditto [Januari] presenteerden die van 't Fort 2000 realen voor mijn verlossinge, daer den Koninck niet na hooren wilde, en strenghelijcker gebonden heeft, ende sondt my soo met twee Engelsen op de walle, recht over de Catte, om 't Fort op te eysschen; soo niet, souden 't 'sanderdaeghs beschieten ende met ghewelt sien in te kryghen; oock niemand in 't leven laten. .... Hierop staende strengelijck gebonden, ende strop om den hals, gaf ons volck moet ende courage inplaets van overgheven te roepen; waer over my' de Javanen van achter over trocken, ende weder langhs d'aerde nae 't Hoff sleepten".

Camphuis gaat nog verder en voegt er aan toe, dat de twee Engelschen de Nederlandsche taal spraken, natuurlijk om te doen uitkomen, dat al wat de held zou zeggen, goed verstaan werd. Gedwongen die van het fort toe te roepen, dat zij zich zouden overgeven, voert de Commandeur een geheel andere taal, "de onzen vermaanende, dat ze nu zouden betoonen opregte Nederlanders en ware Batavieren te zijn", waarop dan weder het achterovertrekken en wegslepen volgt.

Eerst $M^{r}$ van der Chijs vestigde er de aandacht op, dat de geest, die sprak uit Van den Broecke's brieven aan die van het fort, niet in overeenstemming was met de fiere, van doodsverachting getuigende taal, die hij zou gevoerd hebben. Maar het volle licht op de gebeurtenis van 29 December 1618 werd in 1869 geworpen door De Jonge, toen deze met onafwijsbare getuigenissen staafde, dat Van den Broecke in de gegeven buitengewone omstandigheden zich niet heeft betoond een man van buitengewonen heldenmoed en buitengewone zelfopoffering, maar daarentegen een gewoon mensch, die volmaakt hetzelfde deed wat zijne medegevangenen deden. Allen waren onder den indruk van de onmogelijkheid het fort tegen het vereenigd geweld van de Javanen en de Engelschen te houden, en oordeelden dat het verstandigste was, zich onder beding van de gunstigste voorwaarden over te geven. 
Allen is misschien wat te absoluut gesproken. $\mathrm{Er}$ bestaat namelijk een getuigenis, niet van den betrokken persoon zelven, maar van een ander, waarin de zaak geheel anders wordt voorgesteld. In het Rijksarchief (aanwinsten 1859) berust een onuitgegeven handschrift, opgesteld door Walter Breemen van der Hagen en geteekend "den Briel, 8 Februari 1662 . Het geeft in den vorm van een dagregister de geschiedenis van s't Leven en bedrijf van Witte Cornelisz. de With, in sijn leven Vice-Admirael van Hollant ende Westvrieslant». Ieder woord is, naar de verklaring van den schrijver, uit den mond van den Admiraal zelven gehoord "ende genoteert" '

Aan dit handschrift ontleenen wij het volgende. Op elfjarigen leeftijd was Witte Cornelisz, om te kunnen vechten, van Mennoniet lid van de Staatskerk geworden, en na verschillende avonturen, in October 1618 aan boord van de "Gouden Leeuw" voor Jacatra gekomen.

-Omtrent dese tijt heeft den voornoemden President Jan Pietersz Coen sijn Capitein [Geen Huijgen] Schapenham gecommandeert hem te willen laten gaen; is also door desselfs ordre geworden hoffmeester ende lijffknecht van den meergem. Coene, daerna blijvende egter in synen dienst Corporael van de compagnij op 't fort Jacatra". Als zoodanig nam hij deel aan den uitval op 23 December 1618, bij welke gelegenheid hem «sijn rapier van syn lijff» werd geschoten.

Omtrent de houding van Van den Broecke op 29 Januari 1619 wordt gezegd:

«Waerover onse Commandeur Van den Broeck met twee Rade en overige suite uijtgetrocken op 't goede gelooff om met den anderen te comen in bespreck; in plaets van te worden gecongratuleert, wierden gespolieert en gevleugelt in hegtenisse geset; 't welk bij eenige van d'onse wel was te gemoet gesien. Naer dese rencontre wierde den voorsz Commandeur Van den Broeck op 't naeste bolwerck van den viant gevleugelt met een

1 Van het bestaan van dit handschrift maakt.Leupe melding bij een paar korte aanteekeningen onder het opschrift: Pieter Van den Broecke voor Jacatra 1619. (Ned. Spectator 1877, p. 4). De levensbeschrijver meldt nog hoe Witte Cornelisz als korporaal bij „de Compagnie, die d'avant-guarde had", deel nam aan de bestorming van Jacatra, om daarna weder aan boord van de "Gouden Leeuw" onder den Admiraal Steven van der Hagen naar het vaderland terug te keeren. 
strop om sijn hals gestelt, d'onse toeroepende 't fort voorn: aen de Javanen over te geven off anders, dat sy alle lyveloos waren. Van binnen (waer onder desen belliceusen helt met ordre ook een was) tot antwoort, dat parthy moesten weten, dat sy Hollanders waren, die liever te vegten tot den laesten man toe, dan in Barbaren handen te vallen, wordende den voorsz. Commandeur so weder na 't gevangenhuijs gebragt».

Hier is dus de toestand omgekeerd. Van den Broecke maant tot overgeven, maar de dappere Hollanders van binnen verkiezen liever te sterven. Twee dagen later evenwel werd het contract geteekend, waarbij het fort met de goederen in handen der Engelschen en Javanen zou worden overgeleverd.

Coen zegt in zijn brief van 5 Aug. 1619 (De Jonge IV, p. 168) dat "d'Engelssen en de Coninck van Jacatra van den Broecque en eenige andere gevangenen op de stadsmueren brengende, hebben haer aen 't fort doen roepen:.... dat d'onse.... het opgeven souden.» Het dagregister van Hulsebos laat tot 2 à 3 malen toe door Pieter van den Broecke en "Doktoor» de Haan hetzelfde doen. Maar volgens het reeds uitgegeven journaal (dat van 4 Januari tot 11 Mei) zond de "Coninck, (p. 142) eerst Dirck Femming, die zich tot den Kapitein Jan Jansz van Gorkum, en daarna Pieter van den Broecke, die zich tot den bevelhebber Pieter van Raey wendde, terwijl beiden evenzeer wezen op de overmacht des vijands en raadden tot overgaaf, terwijl het nog tijd was.

Overigens vatte Coen deze zaak nuchter op; ze belette niet, dat Van den Broecke na zijn invrijheidstelling met een nieuw bevel werd belast; dat Dirck Jemming korten tijd later tot sabandar van Batavia werd benoemd en dat Dokter de Haan in Juni 1622 als gezant naar Mataram werd gezonden.

$\mathrm{Bij}$ het gebeurde op 29 Januari 1619 werd eenigszins langer stil gestaan, ook omdat in de vermelding daarvan een aanwijzing ligt voor het vaststellen van den schrijver van het door De Jonge gepubliceerde journaal.

Alvorens daartoe een poging te doen, worde nog even gewezen op het groote onderscheid in beide stukken. Duidelijk blijkt het verschillend karakter der samenstellers bij de vermelding der rampaspartij in den avond van 31 Januari 1619. De overeenkomst betreffende de overgave der versterking aan de Jaca- 
tranen en de Engelschen was getroffen; men zou alleen zijn "sijtgeweer» en zijn "kist met goed» mogen medenemen, en het overige moeten achterlaten. Om voor opvolging van deze bepaling te zorgen, zou den volgenden dag een nauwkeurige visitatie door twee Engelsche kooplieden plaats hebben.

«'s Avonts», zoo zegt nú de onbekende schrijver (p. 145) "doen ginck Sr. Raeij met d'ander overicheyt ende braecken den $\mathrm{H}^{\mathrm{r}}$ Generaels, met d'ander coopluyden haer kisten op, die met de vloot wech waren; was daer wat in de kisten, dat haer behaechde, sy namen het al mede ende als der een was, die wat wech stack d'ander sach het, die seyden: "mede samen»; daer was Brackker [lees Brasser] en den hoofmeester [Witte-Cornelisz de With] al mede om te helpen, die kisten op te breken; maer sy hadden daer oock genen schade van, sy hadden haer kisten soo vol goet, dat sij het niet bergen en konden, dat waren fraeye mannen in Pieter Raijs sin," enz.

En de andere, kort en verklarend: "En alsoo niet anders gesien en was off souden de fortresse hebben verlaten, en oock alles ten naeusten ondersocht en gevisiteert worden, syn die van binnen genootsackt geweest, de boeken van de Vereenichde Comp $^{a}$ ende veel andere stucken, die vreese onder hande van d'Engelsen tot grooten nadeele van de Comp ${ }^{\mathrm{a}}$ ende de Generael mochten sijn, int vijer te werpen ende te verbranden, volgens oock de commissie hen bij den $\mathrm{H}^{\mathrm{r}}$ Generael op syn vertreck schriftelijck geordineert».

De eerste ziet alleen de berooving van de afwezigen, de tweede zwijgt daarover en verdedigt de vernietiging van bescheiden, die niet in handen van den vijand mochten vallen.

Van belang voor de opsporing van den schrijver van het afgedrukte journaal is de volgende mededeeling van zijn hand. Den $29^{\text {sten }}$ Januari (p. 143) «liet $S^{r}$ Raye met die Capiteyn den raet vergaren en oock alle ondercoopluyden en assistenten en de sargianten met die constapel majeur ontbieden, om in den raet te wesen; daer ging ons al te samen lyff en leven aen; doen werden ons te samen gevraecht off wy wel moet hadden, dat fort dry maenden te houden om onsen viant wederstant te doen, dat elck syn rechten meyninge uitspreken soude, daer hangt ons al te samen het leven aen».

De schrijver was dus in deze vergadering tegenwoordig; hij was een van de 20 , die te zamen het besluit tot de overgave 
van het fort teekenden. Als Calvinist, deed hij dat berustend; hij beval mede zijn "siel in Godes hant; soo Sijn beste wil is, soo sal het geschien *.

Van de genoemde $20^{1}$ onder welke onze man schuilt, komen niet in aanmerking:

$1^{\circ}$ de commandeur Pieter van Raey, de kapitein Jan van Gorkum, de predikant Adriaen Jacobsen Hulsebos, de koopman Evert Harmansz, als behoorende tot de gesmade hooge overheid.

$2^{\circ}$ de luitenant Abraham Strycker, de vaandrig Hendrick Harmensz en de ondercoopman Joseph de Natlaer, mede persoonlijk aangevallen.

$3^{\circ}$ de onderkoopman Jan van der Dussen, de assistenten Jan de Brasser, Jan Mibayse, Samuel Merchys en Cornelis Jacobsz Gael, de mannen naar Pieter van Raey's hart, die aan de plundering der kisten hadden deelgenomen ${ }^{2}$.

$4^{\circ}$ de sergeanten Willem Hendriksz Jongbloet en Andries Fransen, die niet konden schrijven en met een merk teekenden.

Er blijven dus 6 personen over, namelijck: de schoolmeester Jan van den Broecke, de onderkoopman Melis Remmerts Lants, de assistent Anthonio Meeusen, de sergeanten Dirck Reyniersz en Elias Rippon benevens de constabel-majoor Juriaen Jansz.

Jan van den Broecke (uit Middelburg uitgevaren in 1613) wordt genoemd in verband met den verkeerden aanleg van de zuidoosterpunt, welks tracé niet voldeed aan den eisch van een behoorlijk flankement van het zuidelijk front van het fort langs de kat. Coen had de punt persoonlijk geprojecteerd en met paaltjes uitgezet en Meester Jan schijnt hem daarbij geholpen te hebben, zoodat verwacht werd, dat hij bij de uitvoering de noodige aanwijzingen zou hebben gegeven. Dit was niet geschied. Tot verontschuldiging der gebrekkige constructie beriep men zich o.a. op het gebrek aan planken en op het werkzaam vuur van den vijand. Er is nergens iets te vinden, dat eenige aanleiding geeft den schoolmeester voor den schrijver van het journaal te mogen houden.

Nog minder is een dergelijk stuk te verwachten van Antonio Meeusen (den lateren Gouverneur Generaal van Diemen), buiten zijn schuld gefailleerd koopman, die, met de bedoeling om zich

1 Zie de Sententie op 9 Juli 1619 , Bijl. $X_{s}$

- Zie de Sententie op 5 Oet. 1619, Bijl. XI. De „pampieren" waren door Mibayse en Merohys op last van Evert Harmensz verbrand. 
te rehabiliteeren, onder dezen schuilnaam eerst kort te voren met de Mauritius uit het vaderland was aangekomen.

Van de sergeanten Dirck Reyniersz van Wesel en Elias Rippon wordt gesproken bij gelegenheid van het tumult óp 6 Februari, toen zij getuigenis aflegden tegen den constabel Hans Stockermans en den zeilmaker Claes Gerritsz, die de bezetting trachtten op te zetten tegen het besluit om de sterkte aan die van Bantam, in stede van aan de Engelschen over te geven. Van beide onderofficieren is overigens niets bekend.

Met den constabel-majoor staat het eenigszins anders. Wel wordt hij in het journaal niet met name genoemd, maar van hem wordt daarin toch iets bijzonders gezegd. Over de vergadering van 29 Januari volgt op het hierboven aangehaalde: "doen worden de constabel major gevraecht of daer wel cruit was voor dry maenden, so als wy alle dage gheschooten hadden; doen seyde de constapel major, dat wy noch booven twee schooten cruyt [per dag] niet hadden, als het dry maenden duren soude, doen worde het beslooten by den vollen raet, dat men met den Engelschen Generl. in accoort treden soude", enz.

Zijn mededeeling legde groot gewicht in de schaal, maar als men de antwoorden nagaat, die hij bij zijn verhoor gaf, blijkt dat hij, omstreeks 40 jaar oud, er de man niet naar was, een stuk als het journaal te schrijven. Bovendien bestond er geen reden, waarom hij dat eerst zoo laat en niet bij het begin van het beleg zou hebben ter hand genomen.

Zoo blijft alleen over Melis Remmerts Lants.

Diens persoonlijkheid en de omstandigheden, waaronder hij zich in het fort bevond, verklaren afdoende zijn houding en den bitteren toon van zijn aanteekeningen, Hij had zijn eerste reis naar Indië gemaakt onder den admiraal Steven van der Hagen (1603-1606) en was opperkoopman aan boord van het Fransche schip Montmorency, toen het in Mei 1616 met de Marguerite uit Dieppe zeil ging en in Februari 1617 op de reede van Bantam aankwam. Daar werd hij, met alle andere Hollanders in Franschen dienst, onmiddellijk gearresteerd. Ondervraagd verklaarden allen "eendrachtelijk" niet geweten te hebben, dat de bedoeling was geweest naar Oost-Indië te varen, maar dat zij, toen hun dit ter hoogte van de Kaap de Goede Hoop gebleken was, met geweld genoodzaakt waren verder te gaan. $\mathrm{Z}_{\mathrm{ij}}$ verzochten dan ook in den dienst van de Compagnie opge- 
nomen te worden, hetgeen werd toegestaan. Onze opperkoopman kreeg 4 Maart 1617 een aanstelling tot onderkoopman op f 40 's maands.

Ongelukkigerwijze kwam in het laatst van 1618 een schrijven van de Heeren XVII uit het Vaderland met een bericht, dat voor Melis zeer bezwarend was. Daaruit bleek toch, dat men in zijn geboortestad Hoorn, toen men kennis kreeg van zijn voornemen om zich door een Fransche maatschappij voor een reis naar Oost-Indië te laten aannemen, hem had gewaarschuwd daarvan af te zien. Melis had dientengevolge voor «den $\mathrm{H}^{\mathrm{r}}$ Officier ende Magistraat, 14 Maart 1615 onder eede beloofd, noch in dienst van de Fransche, noch in dien van een andere vreemde natie naar Indië te varen. Dien eed was hij niet nagekomen. Op grond daarvan werd hij 21 November 1618 veroordeeld, om van den tijd zijner aanneming af "geen gagie,, te genieten, en ook "zonder gagie" naar het vaderland terug te keeren.

Zoo was hij dus gedegradeerd onderkoopman zonder traktement in het fort, toen de belegering begon. Ziek en daardoor onverschillig voor hetgeen er om heen voorviel, verliepen de eerste dagen. Maar hij herstelde en teekende toen de dagelijksche gebeurtenissen aan. Hij, de teruggestelde opperkoopman, 44 jaar oud, zag natuurlijk niet. op tegen de personen, onder wier bevelen hij was gesteld, omdat hij zich geenszins hun mindere achtte. En zijn ergernis nam toe, toen hij zag, hoe zij door hun voorbeeld, hun aanzien en waardigheid te grabbelen gooiden. $\mathrm{Zij}$ vonden in hem een streng beoordeelaar, die zelf niet gespaard, ook anderen niet zou sparen.

Welke aanwijzingen zijn er nu, die er toe leiden Melis Remmerts voor den schrijver van het dagregister te houden?

Vooreerst, dat hij, toen hem bij zijn verhoor werd gevraagd, hoe de belegerden tot overleg en accoord met de Engelschen waren gekomen, "verclaert, doordien dat Dircq Femming ende daerna den Commandeur Pieter van den Broeck gebonden op de muijr van de stadt quamen, roepende dat men het fort in handen van de Javanen off Engelssen soude geven, alsmede door seeckere missive door de Engelssen geschreven,, enz. In dit antwoord en in het dagregister, en in deze beide alleen, wordt over het verschijnen van Dirk Jemming en Pieter van den Broecke achter elkander tegenover het fort gesproken; elders worden andere namen genoemd. 
Als alle anderen was hij sober en gereserveerd in hetgeen hij op de hem gedane vragen antwoordde. Opmerkelijk is daarbij, dat over de zaken, waarvan hij verklaart onkundig te zijn, ook geen bijzonderheden in het dagregister medegedeeld worden.

En eindelijk is het volkomen duidelijk waarom, als hij de auteur is, het dagregister niet vroeger dan 4 , eigenlijk eerst 14 Januari begint. Op de vraag aangaande de sterkte van de achtergelaten bezetting bij het vertrek van Coen, luidt het toch: "door sijn siecte nieuwers aff te weten». En op die omtrent de beweegredenen, die geleid hebben tot het geven van 6000 realen van achten aan den Regent van Jacatra: "dat doen ter tijt sieckelijck is geweest, ende derhalven niet en weet waeromme het gelt gegeven is».

Maar 29 Januari was hij voldoende hersteld om ter Vergadering te komen en mede voor de overgave van het fort te stemmen.

Mag en moet alzoo aangenomen worden, dat Melis Remmerts Lants, stadgenoot van Coen, de schrijver is geweest van het bij De Jonge afgedrukte dagregister, dan is de vraag voor wien was dat stuk bestemd? Den $19^{\text {den }}$ Januari besluit hij zijn aanteekening van dien dag met de woorden: "maer het quam met den Coninck op een verraet uit, als U. E. hier naer wel hooren sal, hoe het in 't fort gegaen is». Wie was U. E.?

Het antwoord zou slechts een gissing moeten zijn en kan dus achterwege blijven. Tot nu toe heeft ook een vluchtig onderzoek naar Melis Lants' verdere lotgevallen geen resultaat opgeleverd.

In het dagregister van Ds. Hulsebos komt bij wijze van inwerp een beschrijving voor van den toestand van het Nederlandsche fort bij het begin van het beleg, een beschrijving, die eerst door Van den Broecke en op diens spoor door Camphuis, Van der Chijs en Brumund is gevolgd.

Er heeft een teekening van de versterking bestaan, door Coen bij zijn schrijven van 5 Augustus (De Jonge IV, p. 183) aan de Heeren XVII gezonden, want hij zegt uitdrukkelijk: "Bij dese gaet ontwerp van 't fort Jacatra », en daarop volgt een toelichting, waarop wij hieronder terugkomen. Dit ontwerp van de oude versterking, dat zooals De Jonge in de noot op p. 183 aanteekent, zou berusten in het Rijksarchief, is daar niet aanwezig, en zoover 
kan worden nagegaan, daar ook nimmer geweest. Er heerscht hier verwarring met een ander plan: het project van het nieuwe fort, waarvan melding gemaakt wordt in Coen's missive van den $7^{\text {den }}$ October. Dit laatste is $\mathrm{n}^{0} 1176$ van den Catalogus der Kaarten in het Rijksarchief en als Bijlage XII ${ }^{\mathrm{a}}$ afgedrukt bij Hoetink's opstel over So Bing Kong '.

Op dit latere plan komt de omtrek van het oude fort in getrokken lijnen voor. De schaal is klein, 25 Rijnl. Roeden op den duim, of $1: 3600$. Het was niet goed doenlijk, binnen den omtrek eenige détails te teekenen, maar dit werd ook niet noodig geoordeeld, omdat twee maanden te voren een afbeelding, waarop alle bijzonderheden voorkwamen, verzonden was, en dus mocht worden aangenomen dat deze volkomen bekend waren.

Onder die omstandigheden geeft Hulsebos' dagregister een zeer gewenschte aanvulling.

Met een enkel woord moge worden herinnerd aan de geschiedenis der oprichting van de Nederlandsche loge te Jacatra. Nadat eerst door L' Hermite en later door Both besprekingen waren gevoerd met den Regent omtrent den afstand van een stuk grond, en men daaromtrent tot overeenstemming was gekomen, had Henrick Brouwer in 1611 de definitieve plaats van vestiging uitgekozen. In 1613 was daar een groot steenen huis gebouwd, lang 50 en breed 18 treden ( 1 pas of trede $=\frac{1}{6}$ R. R. $=0.63$ M.) en een kleiner begonnen. In 1618, toen Coen te Jacatra verblijf hield werd ook dit laatste voltooid. Beide gebouwen dienden voor pakhuis of gèdong, en hadden een verdieping, ingericht voor logies. Aan het nieuwe was een rondloopende bovengaanderij aangebracht, waarop den $20^{\text {sten }}$ Augustus 1618 soldaten werden opgesteld, die Pangéran Gabang van zijn aanslag op de loge terughielden.

Andere gebouwen, werkplaatsen, woningen voor ambachtslieden, een ziekenhuis, enz., samengesteld uit hout en bamboe en gedekt met atap, stonden met de pakhuizen binnen een omheining. Waarschijnlijk mede daarbinnen lag een tuin met een vijver voor ganzen en eenden; ook kippen en duiven

1 De hierboven vermelde noot van De Jonge behoort alzoo te staan op p. 191 , in stede van op p. 183 van zijn werk. 
werden daar gehouden, terwijl 100 stuks koeien en 80 bokken en geiten er stalling vonden. ${ }^{1}$

Onder den indruk van het gevaar, dat van de Javaansche vorsten dreigde, had Coen de noodzakelijkheid ingezien om maatregelen tot meerdere veiligheid voor hem en de zijnen te treffen. In stilte was een gemakkelijker te verdedigen sterkte « in 't kleen afgeteekend, met palissaden bezet en aldaar allenskens met aerde omworpen». Maar 22 October 1618 werd in een generale vergadering van 7 opperkooplieden, 11 schippers, 5 sergeanten en den commandeur Arend Maartensz., door Coen aan boord van "Het Wapen van Amsterdam» belegd, in welke ieder schriftelijk zijn advies uitbracht, eenparig besloten de begonnen werkzaamheden voort te zetten en, "een volcomen fort te voltrecken.» ${ }^{2}$

THet fort had, zooals uit het plan blijkt, nagenoeg den vorm van een vierkant, met kleine bastions op de hoeken. Het oude pakhuis Nassau vormde de courtine of het gordijn aan de zuidzijde; het nieuwe, Mauritius, dicht aan en evenwijdig aan de rivier gelegen, die van het westfront. De noordzijde langs het strand en de oostzijde, waartegenover zich eenig houtgewas bevond, waren door aarden borstweringen afgesloten, 9 voet hoog en 6 à 7 voet dik.

De rivierpunt (N.W.) aan het huis Mauritius was 23 December slechts 2 voet opgehoogd en daarop de bedding van het geschut gelegd; de borstwering bestond uit zwalpen, houten platen, die geen voldoende beschutting boden voor musketschoten.

Het strand en dus de noordzijde van het fort werd bestreken door een batterij aan de overzijde, op den verder uitspringenden westelijken oever der rivier, de zoogenaamde Paap Jan's batterij.

Met de zeepunt (N. O.) was het iets beter gesteld; deze was reeds 9 voet opgehoogd, had een borstwering van palissaden en een houten dak, om de bedieningsmanschap tegen vuur en regen te beschermen.

Aan de Z. O. punt naast het huis Nassau was nog niet

1 Zie hierachter Bijl. XII : Notitie van't gene tot Jacatra in den oorloge tot fortificatie in de Punten als andersints tot defencie geconsumeert is.

De „Koyen” (De Jonge p. 140), die de „Coninck ... noch bewaert hadde", zijn hiermede terecht gebracht.

${ }^{2}$ Zie Bijlage III.

Dl. 73. 
begonnen; daar moest men zich behelpen met een/nieuw gemaakte gaanderij aan dat huis, van waar eenig, maar onvoldoend flankvuur kon worden gegeven.'

Tusschen de beide huizen aan de Z.W. punt werd met spoed een kat of hooge batterij opgeworpen, welke door gebrek aan werkvolk slecht vorderde. $\mathrm{Zij}$ steunde op een gemetselde steenen voet, die niet zoo hoog kon worden opgetrokken als gewenscht werd. Het steile talud werd daarom verder met koraalsteen zonder specie opgezet. Den $23^{\text {sten }}$ December had de kat nog maar een hoogte van 9 à 10 voet bereikt. Men had daarbij te kampen met verzakking van den slappen bodem; de vaste zandgrond lag $1 \frac{1}{2}$ vadem diep. ${ }^{1}$ Ten einde in het flankement van het zuiderfront te voorzien, waarop de kat niet was ingericht, moest bijzondere voorziening getroffen worden.

Het bovenvlak der kat zelf werd in onvoltooiden staat met schanskorven, linnen zakken (met zand) en kostbare pakken kleeden beschermd, om de manschap aan het geschut dekking te geven.

In het bijzonder hadden de huizen van het geschutvuur te lijden; Mauritius uit een vlak daartegenover gelegen batterij in het Engelsch kwartier, Nassau uit twee batterijen in het Chineesche kamp naast het huis van den meermalen genoemden Watting. De kogels sloegen door het logies op de verdiepingen; herhaaldelijk 'door de slaapkamer van Coen. Den $9^{\text {den }}$ Januari 1619 werd de predikstoel in de groote vergaderzaal getroffen. Dit vuur noodzaakte een tijd lang om op den beganen grond verblijf te houden.

$\mathrm{Na}$ het vertrek van Coen begon Van den Broecke met het opwerpen van de Z. O. punt, naast de kamer van De Carpentier in het oude huis; aan de andere zijde van dit huis bevond zich de bottelarij.

De kat en de zuidoostelijke punt (zooals Coen 5 Aug. schrijft, "scheef stant gemaeckt», hoewel zulks niet uit het plan blijkt), beide ingericht om krachtig vuur te geven op de aan de overzijde gelegen kota Jacatra en hare versterkingen, waren een doorn in het oog van den Regent, omdat daardoor de dalěm en de mesigit voortdurend bedreigd werden. Van daar zijn zonder. ophouden herhaalde wensch beide af te breken.

\footnotetext{
1 Zie letter $y$ op de legenda van de hiervoor vermelde reproductie van het latere plan van het fort.
} 
Na de gevangenneming van Van den Broecke op 23 Januari, werd begonnen met het dragen van aarde in het huis Mauritius tegen den buitenmuur en 3 Februari deed men hetzelfde in het huis Nassau, om meerdere veiligheid tegen het vijandelijk vuur te hebben.?

In zijn bovenaangehaald schrijven van 5 Aug. 1619, waarin hij aankondigt dat een geheel nieuw fort met nieuwe huizen gemaakt moest worden (p. 184), beschrijft Coen den toestand bij het einde van het beleg als volgt: ${ }^{1}$

"Het oude groote huijs is in den oorlooch halff affgebroocken (om de val voor te comen), ende nu met een seijl gedect, waer in ons behelpen, ende U.Ed goederen bewaeren moeten; de rest staet mede om te vallen. Ende alsoo aen de eijnden van 't nieuwe huijs twee bolwercken gemaect zijn, sijn beide dese eijnden ontrent 3 voeten nedergesoncken ende het midden is staen gebleven als het was, soo dat de muijren eer dermaten van malckanderen gescheurt zijn. Het fort is te cleijn om de behoorlijcke huijsinge daer binnen te maecken. Van de vier bolwercken liggen de drie op de drie hoeken van een rechtzijd[ich] vierkant; maer het vierde is (na mijn vertreck wt het fort) dicht aent oude huijs dan scheeff stant gemaeckt. In voegen, dat de voorneemste lantpunt niet geflanckeert cost worden. Daerover is tusschen de twee lantbolwercken noch een cleen werck gemaeckt. Het nieuwe huijs staet soo dicht aen de riviere, datter geen spatie resteert om een walle er tusschen te maecken .

«Hierover 'hadden geresolveert (p. 184) op de westzijde van de riviere (daer de stad Jacatra gelegen heeft) een nieuw fort te maecken», enz.

Een der overwegingen om de nieuwe versterking op den linkeroever der rivier te maken, was, dat die verder uitspringende oever een gevaar bleef voor elk verdedigingswerk aan de overzijde. Aan dit bezwaar kon tegemoet gekomen worden door de noordzijde van het nieuwe fort meer zeewaarts te brengen, hetgeen volgens het project ook heeft plaats gehad. Overigens bestonden verschillende redenen voor het blijven op den rechteroever.

Zoo viel dan ook, zooals Coen (p. 190) 7 October schrijft, de beslissing in dezen zin. "Nadat ons lange bedocht ende lange

1 Bij De Jonge weggelaten. 
gedelibereert hadden, wat versterckinge hier maecken souden, is eijntelijck goetgevonden een nieuw fort te beginnen groot 50 quadraet roeden, ende om t selvige met gemack ende te meerder verseeckerheyt te mogen doen, dat hetselvige buijten om het oude fort leggen sullen. De fondamenten van de landtpunt hebben nu begost, als die gemaeckt zij, sal 't oude fort dubbelde versterckinge hebben. Godt geve dat het werck geluckich voleijndt mach worden. Bij dese gaet project hoe het werck gedissegneert wort ».

Dit nu was het gestippelde project waarvan hiervoor op p. 574 is gesproken en waarop het westfront van het nieuwe fort het oostfront van het oude omvat.

Bezuiden het fort is in getrokken lijnen een omheinde rechthoek geteekend, welks zuidzijde, met twee punten voorzien, ongeveer samenvalt met die van het latere Kasteelplein, de groote markt (ongeveer $340 \mathrm{M}$. van het midden van het fort).

De Oostzijde is met een stippellijn verlengd en eindigt in een punt, van welke - eveneens gestippeld - een nieuwe zuidelijke grenslijn naar de rivier getrokken is. Deze nieuwe grenslijn komt nagenoeg overeen met de Utrechtsche straat, $\pm 700^{\circ}$ M. van het midden van het fort. Zooals 't "Register vant fort ende omleggende landt Jacatra" (de naamsverandering was door Coen nog niet aanvaard) aangeeft, vormden beide aangeduide oppervlakken "het quartier, daer de Chinesen ende getrouden woonen, sijnde alrede vol huijsen». De voorgenomen uitbreiding van de jonge stad in het laatst van 1619 wordt door dezen eersten plattegrond bepaald, en tot Coen's vertrek op 2 Februari 1623 zou hare bevestiging naar het zuiden op de voorgestelde wijze begrensd blijven.

De tweede bekende plattegrond van Batavia is een ruwe schets, voorkomende in de verhandeling van Dr. Swaving, Batavia's sanitaire geschiedenis (Jg. 1878, Ned. T. v. Geneeskunde), en mede bij Brumund, Een en ander van het Oude Batavia (T. Bat. Gen., Dl. XXV, 1879, p. 362).

Deze schets doet door den vorm van den oostelijken wal met zijn zwaluwstaarten meer denken aan het werk van een timmerman, dan aan dat van een vestingbouwkundige. Er is geen sprake van een schaal en van behoorlijke verhoudingen, maar feitelijk strekt de stad zich zuidelijk even ver uit als de stippellijn 
op het project van Coen. Slechts de breedte is grooter geworden, en de oostelijke grens belangrijk verschoven. De voorgenomen aanleg bleek al dadelijk te klein.

Merkwaardig is deze schets door hetgeen, zij het dan ook zonder aanspraak op nauwkeurigheid, daarop is voorgesteld. Aan de overzijde der rivier vindt men de tolhuizen, de redoute van den havenmeester, de scheepstimmerwerf, de bergplaats der langs de kust gebruikte tingans, het Engelsch kwartier (benoorden de Utrechtsche straat), een redoute en de stalling voor het vee der Compagnie.

Op den rechteroever bezuiden het fort komt eerst de groote markt met de vischmarkt; dan volgen blokken woningen, te zamen ongeveer $340 \times 200 \mathrm{M}$., begrensd aan de Oostzijde door de Tijgersgracht en aan de Zuidzijde door de Leeuwegracht. Aan het eind van de Heerestraat, die niet is aangeduid, staat de Heerepoort. Daarna is aangeteekend de "uitnemende plaisante plaats» (verg. Van der Chijs, Ned. te Jacatra, Bijlage IV, het hof van den opperkoopman Breekvelt) en eindelijk Brasser's redoute.

Deze redoute is opgericht in 1620. Dr. F. de Haan haalt in zijn opstel „Kota Tahi” (T. Bat. Gen. Dl. XLII p. 571) de Resolutie aan van G. G. en Raden van 12 Januari 1621. "Also den aanwas van de burgerije tusschen Schilders tuijn en het kleene rivierken, aan geene sijde [van]. de redoute beoosten de groote riviere buijten de stad gelegen, dagelijks seer begint toe te neemen en te accresseeren, is goedgevonden den persoon van Jan Anthonissen de Brasser op de voorschreven redoute wonende, tot overhooft daarover te stellen omme daarover in tijde van oproer en tumulte te commandeeren .

Hieraan kan nog worden toegevoegd, dat men aan het slot derzelfder Resolutie leest: "Aan Jan Anthonisz Brasser tot soulagement van sijne dispensen aan de redoute gedaan hondert realen ».

Volgens het "Boek van Leningen» (Overgekomen brieven 1623) werd op 1 Mei 1620 aan "Andries Gabrielsz van Antwerpen, in de wandelinge Schilder genaemt, vrijborger alhier , voor twee jaar in leen gegeven een hof of boomgaard, "ruijm één musquetscheut bij zuijden de nieuwe stadt aen d'oostsijde van de riviere gelegen». Deze maat is een vingerwijzing voor den afstand van de redoute tot de Heerepoort; ze lag zeer zeker binnen de eerstvolgende uitbreiding, welke eerst ter hand 
werd genomen door Coen's opvolger Pieter de Carpentier. Zoolang Coen Gouverneur-Generaal was, vorderde de opbouw van het kasteel alle inspanning van krachten; maar 3 Januari 1624 kon De Carpentier schrijven "sedert de heer Generael Coens vertreck hebben de stad aen d'oostsijde van de riviere ruym een darde part uitgeleyt, met een gracht ende aerde wal beginnen te omsingelen ende te sluyten, gelyck UEd. in nevensgaende pourtraict van Batavia sien zullen». En verder: "Van dit voorleden drooge mouson is $\mathrm{d}^{\circ}$ wal begonnen ende gebracht tot op 190 roede in lenghde, met twee cleene bolle wercken daer ingereeckent» Eindelijk: "Tgene noch tot voltreckinge van voorsz. wal aan de oostzyde van de stadt naer 't fort gebreect, synde ruym noch een darde part, hoopen wy met Godes hulpe 'taenstaende drooge mouson buyten Comps last af te maecken.»

De oostzijde der stad verkreeg dus een lengte van meer dan 250 R. R. of 940 M., d. i. zoover als ze zich tijdens de belegering in 1628 uitstrekte.

Van die uitbreiding naar het zuiden blijkt op de schets niet. Wel schijnt een uitleg naar het oosten reeds te hebben plaats gehad. Op den eersten plattegrond toch $\left(\mathrm{n}^{\circ} 1176\right)$ valt de oostgrens der stad ongeveer in één lijn met de oostelijke punten van het oude fort; op de schets is zij oostwaarts verplaatst, zelfs verder dan werkelijk het geval was.

Uit het ontbreken der groote uitbreiding naar het zuiden mag worden afgeleid, dat de schets vervaardigd is vóór den drogen mousson van 1623 .

Een andere grens voor den tijd van haar ontstaan is gelegen in het feit, dat de Engelsche loge als geheel voltooid wordt voorgesteld. Aangezien de grond voor die loge op 1 Juni 1620 werd afgestaan, kan worden aangenomen, dat de gebouwen niet vóór begin 1621 gereed zullen zijn gekomen. ${ }^{1}$

De schets dateert dus uit 1621 of 1622 .

Van het "pourtraict" van de stad, overgezonden door De Carpentier, is tot dusver geen spoor gevonden.

Tot slot moge nog een oogenblik worden stilgestaan bij de oude inlandsche stad Jacatra. Ze bestond uit een kern op den linkeroever der Tjiliwoeng, de eigenlijke kota, omheind en van

${ }^{1}$ Verg. ook Calendar of State Papers, East-Indies(1617-1621), p. 404: 1620. Dec. 31. Our building bere is pretty well finished". 
wallen en muren voorzien; daar buiten lagen aan weerszijden van de rivier kampoengs. Een daarvan, naar de beschrijving, bezuiden het Chineesche kamp en zich ook meer oostelijk uitstrekkende, stond onder Kjai Aria, "den Graaf » of het "Graafken *

Waarschijnlijk als gevolg van den voortdurenden aangroei van het strand door aanslibbing, bestond er een afstand van meer dan 300 M. tusschen de enceinte der kota en de zee.

Evenals in Bantam waren in Jacatra de vreemdelingen zorgvuldig buiten de kota gehouden. Deze handelaren hadden zich ook hier bij voorkeur gevestigd nabij den mond der rivier. Eerst werd daar plaats afgestaan aan de Chineezen; daarna aan de Hollanders, voor wie de Chineezen hadden moeten opschikken; ${ }^{1}$ en eindelijk aan de Engelschen op de meest gunstig gelegen plaats op den linkeroever, vlak tegenover de Hollanders.

Sedert jaren bestond bij den Regent het plan de kota met een muur te omringen, hetgeen niet alleen zou dienen tot verdediging, maar in zich sloot, naar Javaansch begrip, het gevoel van meerdere onafhankelijkheid. Volgens Van der Chijs (p. 39) zou Matelief reeds van dit voornemen gehoord hebben. Onzeker is, hoever hij met de uitvoering in 1618 was gevorderd, maar vast staat, dat toen met kracht de hand aan het werk werd geslagen, ten einde het zoo spoedig mogelijk te voltooien. Hij belette de levering van hout en steen aan de Hollanders en maakte gaarne gebruik van de aangeboden hulp der Engelschen. «Een muer met verscheyden bolwercken aen d'een zyde van de stadt tegen onze huysen overstaende, werd "voltrocken». (De Jonge IV, p. 114, 115).

Batterijen waren op verschillende plaatsen, zoowel binnen als buiten de kota opgericht; aan den zeekant, ter bestrijking van den riviermond en het noordfront van het fort, Paap Jan's batterij, welke naam herinnert aan den geheimzinnigen Priestervorst van Abyssinië; dan recht tegenover het huis Mauritius in de Engelsche loge "recht op onze neuse», een tweede; vervolgens werden verscheidene stukken geplant aan den rand der kota, in het bijzonder in den noordoostelijken hoek op een hooge steenen kat.

Op den rechteroever sloot zich daarbij aan een batterij nabij het huis van den Chinees Watting; later werd daarnaast, maar dichter bij het fort, een tweede opgericht.

1 Vergelijk Hoetink, So Bing Kong, p. 347. 
In de kota zelf had men zich zorgvuldig tegen de uitwerking van het kanonvuur uit het fort trachten te beschermen. "In 't hoff ", schrijft Coen (p. 115) "is mede bedectelijk een werck schootvry voor groff geschut gemaect, gelyck ook in alle de huysen van de voornaemste Orang Cays, en dat uyt vreese (soo zy seyden) dat wy van de cadt in de stadt schieten zouden». Dit belette niet dat er toch vele slachtoffers vielen, zoo een der bijvrouwen van den Regent, zoo de hoofdpangoeloe van de moskee.

De ligging van het verblijf van den vorst is met voldoende nauwkeurigheid bepaald.

Pieter van den Broecke zegt dienaangaande ${ }^{1}$ : Alhier versochten d'Engelsche (1620) weder een Huys op haer oude plaetse; 't selve in consideratie ghenomen zijnde, vermits soo na onder ons Fort stondt, is haer afgheslagen, ende een in de oude stadt ontrent het Konincks Huys vergunt, daer niet seer wel in te vreden waren.

Nauwkeuriger omschrijving vindt men in de aanhaling uit het Boek van Leningen, door Hoetink, Bijlage II $d$. Daaruit blijkt dat op 1 Juni 1620 een stuk grond van 25 roeden (Rijnlandsch) in het vierkant aan de Engelschen is uitgegeven, sgelegen aen de westsijde van de riviere, in de oude stadt Jacatra, tegenover de nieuwe stadt, daer eertijts 't voorhof van den gewesen Coning. van Facatra plach te staen».

De tweede Engelsche loge geeft dus den sleutel voor de bepaling der ligging van het centrum der kota. Men vindt haar aangegeven op latere plattegronden van Batavia; op die van den ass-landmeter Frans Florisz van Berkeroode, vervaardigd na de eerste belegering van Batavia door de legers van Mataram, en geteekend 3 Maart 1629 , en op die van den gezworen landmeter Jacob Cuijck, opgenomen na de tweede belegering en slechts gedateerd 1629.

Beide voorstellingen wijken echter belangrijk van elkander af.

Uit Coen's brief van 31 Juli 1620 (p. 208) blijkt, dat na eenige voorafgaande bespreking, door de Engelschen onder meer een terrein werd gevraagd op den westelijken oever der Tjiliwoeng, binnen een musketschots afstand van het fort, waar vroeger het voornaamste bolwerk (de Kat) van den Regent van Jacatra gestaan had. Dit werd te dichtbij geoordeeld en een

1 Korte historiael ende journaelste Aenteykeninge. Haarlem 1634, p. 122. 
ander stuk aangeboden, omtrent een steenworp hooger op de rivier gelegen, dat na heel wat tegenstribbelen werd aanvaard.

Schat men een musketschot afstand uit die dagen op $200 \mathrm{M}$., en een steenworp op 60 , dan komt men tot 260 M. te zamen. Meet men den afstand van de loge tot de punt van het bastion Diamant op de beide genoemde plattegronden, dan vindt men bij Berkeroode \pm 430 M. en bij Cuijck \pm 600 M. De eerste voorstelling komt alzoo het dichtst bij de waarheid.

Beziet men de kaart van Van Berkeroode ${ }^{1}$ nader, dan merkt men even benoorden de Engelsche loge een weg op, die in westelijke richting loopt en zich op $105 \mathrm{M}$. van de rivier splitst; een andere weg loopt zuidelijk langs de rivier en buigt later eveneens naar het westen om. Tusschen deze beide wegen, die na de verwoesting van den dalěm zeker nog eenigen tijd in stand zijn gebleven, heeft meer dan waarschijnlijk het vorstenverblijf met toebehooren gelegen. De voorhof of aloon-aloon lag dan aan eerstgenoemden weg, en daar bezuiden de woning van den Regent.

Evenals bij alle Javaansche vorstenverblijven vond men den měsigit aan de westzijde van het voorplein. Onmiddellijk benoorden daarvan is de markt of pasar te zoeken, waarop de bezetting in den tijd der vriendschappelijke verhouding, hare inkoopen deed.

Hiermede is in overeenstemming de Resolutie van 19 Maart 1620 (Van der Chijs, p. 190 en 191), welke bepaalde dat geweigerd zou worden den Engelschen het terrein af te staan hunner oude vestiging, "om reden daar de timmerwerf der Compagnie en de bergplaats hunner vaartuigen was», maar dat men "haer een bequame plaetse op de markt, daer voor desen de stadt van den Koning heeft gestaen, sal aenwijsen ende vergunnen .

Het geheele complex voorhof en dalěm zal ongeveer $240 \mathrm{M}$. diep en $100 \mathrm{M}$. breed zijn geweest. De plaats zal ongeveer overeenkomen met de tegenwoordige stadswijk tusschen de Kali Běsar, en de Roea Malaka, ter weerszijde van de Utrechtsche straat. ${ }^{2}$

1 Verkleind gereproduceerd in de Bijdr. T. L. en V. van N. I. Nieuwe Volgr. Dl. iI, 1859. - Verg. over Van Berkeroode het opstel van Hoetink p. 367 , noot 4 .

2 Vergelijk de schets hierachter, waarop het oudste gedeelte der stad gestippeld is aangegeven. De zuidelijkste in oost-westelijke richting loopende straat is de Gedempte Leeuwegracht of Utrechtsche straat. 


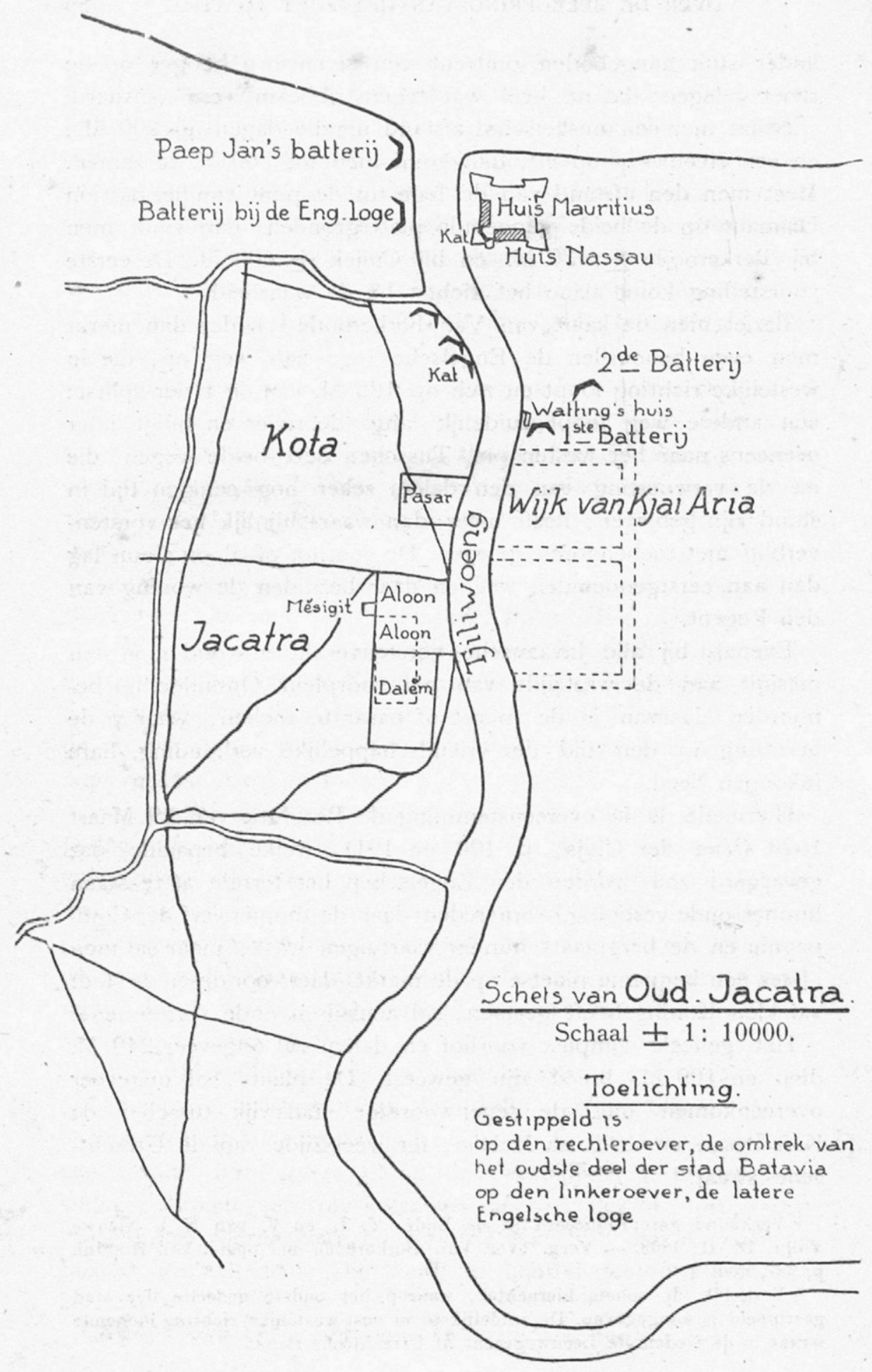


Omtrent de uitgebreidheid van de oude kota Jacatra is niets met zekerheid te zeggen; toch bestaat er groote waarschijnlijkheid, dat haar grenzen waren de Tjiliwoeng en de rondloopende gracht, welke in 1629 op de kaarten van Van Berkeroode en Cuijck geteekend werd. Nadat toch Coen 30 Mei 1619 de kota had vermeesterd, werden de daarin staande huizen, met den dalem en de měsigit in brand gestoken en de muren der versterkingen geslecht. Evenwel niet volkomen; in de resolutie van 3 Juni 1620 komt o. a. het volgende voor: "de principaelste vastigheyt ende bolwerck van den Koning van Jacatra, " "sijnde jegenwoordig nog maer halff afgebroocken ende uyter natuuren so sterck, dat men 't met geen cartouwen soude konnen omverre schieten».

Een deel der wallen en muren zal mede in stand zijn gebleven, omdat het belang yan geheel razeeren niet bestond. De enceinte van de oude kota met hare grachten vormde de aangewezen verdedigingslinie van Batavia aan de westzijde, welke na het eerste beleg der stad werd gereed gemaakt, en haar tegen een nieuwen aanval van de Matarammers moest dekken.

De bevestiging der stad aan de zuidzijde in het oosten beginnend, liep in 1629 van het blokhuis Utrecht langs twee wachthuizen naar het blokhuis Brabant aan de rivier; zette zich aan de overzijde voort langs de wambuizen Vianen en Zeeland, het zuidwestelijk steunpunt en liep van daar noordwaarts op langs de wambuizen Bommel, Weesp en Buren. Tusschen de beide laatste boog de gracht in oostelijke richting af, om tegenover de zuidwestpunt van het oude fort aan de Tjiliwoeng uit te komen.

In Van den Broecke's Korte Historiael ende journaelsche Aenteyckeninghe komt een zeer fraaie gravure voor van Batavia in vogelvlucht, vervaardigd door Adriaen Matham. Deze is gereproduceerd o. a. in Valentijn D1. IV p. $91^{1}$.

Is de bovenstaande onderstelling juist, dan zou de noordgrens der kota Jacatra \pm 330 , de westgrens \pm 820 , de zuidgrens \pm 420 en de oostgrens $\pm 830 \mathrm{M}$. lang zijn geweest.

De uitbreiding van Batavia heeft deze grenzen uitgewischt; de nieuwe stad op de westzijde der rivier zou weldra de oude op den oostelijken oever in omvang op zijde streven.

1 Verg. Brumund p. 373. Ook, maar slecht en als spiegelbeeld in de ${ }_{n}$ Korte Historiael ende Journaels aenteyokeninge" van David Pietersz de Vries. Hoorn 1655. 


\section{Bijlage I.}

Rijksarchief.

Register van de overgecomen

brieven en papieren 1620 .

Dl. I, fol. 215.

\section{JOURNAEL GEHOUDEN IN DE BELEGERINGE, INT FORT JACATRA. '}

2 Naer dattet de Heere belieft hadde de Vereenichde OostIndische Comp ${ }^{a}$ naer veel jaren excessive oncosten rijcke goederen ende middelen te verleenen ende dies halven goede menichte van volck ende groote schatten in de Indias ende onder andren op Java tot Jacatra en Bantam in hunne logimenten ende packhuijzen hadden geformt ende opgelegt hebben, sulckx 'd' inwoonderen, doch voornementlijck de Coningen en den adel des lants, grotelijckx beginnen te misgunnen, vreesende, soo t schijnt, dat $\mathrm{t}$ hen lichtelijcken thans oft morgen eenige plaetsen affhandich gemaeckt ofte ten minsten bij geintresseert mochten worden;

1 Wanneer in de volgende noten verwezen wordt naar het onuitgegeven, grootere handschrift van Van den Broecke, dat voor zoover betreft het voor. gevallene te Jacatra in deze periode, grootendeels een afschrift is van dit journaal, zal zulks aangeduid worden door B I.

Het "Korte Historael enz" wordt aangehaald als B II.

9 B I zegt: Den 7e ditto [November 1618] naer middaech arriveerden ick Godtdanck wederom tot Jacatra alwaer den E. Heer Gouver Genal Jan Pieterssen Coen met den oppercoopman Pieter de Carpentier lagen, verstondt van het veraet dat die van Bantam met die van Jacatra tegens den E. Heer $G_{e n}{ }^{a l}$ Coen ende alle de compes dienars op 20 Augustus 1618 voorgenomen hadden, waer tegen hem de E. Heer Genal socht te verseckeren met des comps goederen, soo datsse seer iverich donde waaren een fort tegen de Javannen op te werppen. 'Smorgens tegen den dach sach ick de commetstarre met een stardt recht boven de looghe versijnen.

Aldus verkhonden hem de Commidtstaere. [De teskening ontbreekt].

Den $15^{\circ}$ ditto [December 1618] vertroeck ick voor oppercoopman met het schip den Engel in comp' van Willem Janssen naer Souratte, om aldaer voor hoofft te liggen.

Den $16^{\text {on }}$ ditto tegens den avont soo wij om den hoeck Onton Javan genamt rescontreerde ons een vliger commende van Bantam ende een Duijdtsman, die ons tijdingh brachte, dat de Engelsen den Swarten Leuw commende van Patanni voor Bantam met veraet genomen hadden; resolverde op die tijdingh niet voordts te loopen maer wederom te keeren naar Jaccatra om d'advies van de E. Heer Gen al te hooren.

Cordt verhael in wadt mannieren de questien ende orlooch tot Jaccatra met onsse natie eerst begonnen is.

Naer dat het de Heer belieft hadde de Vereenichde Oost Indische Compie, enz. 
waerover sommige coningen en vorsten princepalijck bij die van Bantam ende Jacatra en verso heymelicke verbintenisse geformeert ende veel listige lagen aengeleght werden omme de Nederlansche Comp ${ }^{a}$ van hunne toebehoorende schatten te onblooten, hunne dienaren te vermeesteren ende de comptoiren affloopende, alles tot ende aen hen selven te nemen; ten welcken fijne Pangoran Gabangh, broeder van den Coninck van Bantam ${ }^{1}$, quansuijs al speelenvarende, op 20 Aug $^{\text {to }} 1618$ ten hove bij den Coninck van Jacatra, en van den selven dach savons naer den gebeden, de clocke ontrent 8 ure, onder pretext vande $\mathrm{E}$. $\mathrm{H}^{\mathrm{r}}$ Generael Jan Pietersz. Coen te comen besoecken ende des $\mathrm{Comp}^{\mathrm{a}}$ logie eens te besichtigen, met ontrent 500 man inde logie aldaer vervoecht heeft; houdende buijten rontsomme de heijningh van selve logie noch ontrent 200 van de sijne ende ontrent 3 à 400 van des Coninghs volck van Jacatra; meynende alsoo zijn bevoornemen ende verraderije op seeker gegeven lose ${ }^{2}$ aen te vangen in effecte te brengen. Twelck d' almachtighe Godt genadichlijck heeft verhindert; want alsoo door bevel vande $\mathrm{E}$. $\mathrm{H}^{\mathrm{r}}$ Generael voornompt de soldaten opt nieu huijs, Mauritius genaempt, bedecktelijken in hunne wapenen te staen geordonneert was, oock mede de borgerije gewaerschout sich bij haer logimenten [te] onthouden, is sulcx bij den voorn. Gabangh gemerckt en daer bevindende beyde de huijssen stercker ende de logie met meer volck voorsien als wel vermoet hadden, vant hem bedrooghen ende verbaest, en so aenslach staeckende, is met eenen droeven ende geveijnsden adieu wederomme naer Bantam vertrocken ${ }^{3}$, voor welcke genadigen bescherminghe Godts op den 23 derselve openbaren dancksegginge geoeffent is. Hier op $\mathrm{nu}$ is gevolcht, dat bij den E. H. Generael goet gevonden is deselve plaetse van Jacatra om de goederen van de Comp ${ }^{a}$ ende $t$ leven van hunne dienaeren te bewissen ${ }^{4}$, wat meer tegen den ontrouwen Moor te verseeckeren; ende alsoo w[ert] int eersten de logie int cleen affgetekent met palasaden beset en aldaer allenskens met aerden omworpen, die bij den Coninck van

1 Pangeran Gabang, broeder van den Rijksbestierder van Bantam, Pangeran Aria Mangala. De naam van den Regent van Jacatra was Widjaja Krama (Widiak Rama).

"Lose, loose (B I zegt: "losse") = teeken, wachtwoord, wapenkreet.

s Verg. De Jonge, Opkomst IV p. 99. Brief Coen aan H. XVII, 29 Sept. 1618.

- Bewissen $=$ verzekeren. 
Jacatra gemerckt synde, heeft oock sijnen stadt leggende tegens over de Comp ${ }^{\mathrm{a}}$ logie beginnen te verstercken ende met nieuwe muijren te voorsorgen, ende ten laesten siende de eenen des anders voornemen, ist soo verre gecomen, dat bij den $\mathrm{E} . \mathrm{H}^{r}$ Gouverneur Generael ende raedt den 22 October rondelijcken is geresolveert, de voornoemde logie tot Jacatra tot een defencijff casteel ofte fort te voltrecken ${ }^{1}, \mathrm{t}$ welck oock opt spoedichste aengevangen ende begonnen wert. Den Javaen ondertusschen niet rustende, heeft verscheijden baterijen, soo buijten als binnen de stadt, opgeworpen, ende met stucken geplant, alsoo dattet aen beijde sijde niet dan met groote jalousie ende achterdencken geschiede, ende voornamelijck ende met recht van Nederlanders, dewijle seeckeren orang caijen ${ }^{2}$, die scheenen ofte veijnsden hun een goedt herte toe te dragen ende verscheijde mael hen gewaerschout ende aengeseijt hadden, dat op hoede soude zijn als wel wetende, datter ijets quaets voor handen waere; en alsoo de Javaenen door de meenichte van volk en ruijmte van materialen eenen goeden tijt voor de Nederlanders haere wercke hadde volbracht en noch daer en boven den 22 snachs ${ }^{3}$ in alle haest een baterije oft bolwerck van houdt, cabels ende aerde genochsaem tegen een scheute groff geschut inde Engelsche logie recht tegen het fort achter $\mathrm{t}^{\prime}$ nieuwe huijs ${ }^{4}$ hadden opgeworpen, twelck apparentlijck in corten tijt tot een groote en vaste stercte soude connen opgemaeckt worden, en den Javaen alsoo gewisselijcken sonder lange toeven haere macht tegen 't Nederlantse swack ende eerst nieu begonnene fort opt onversienste soude hebbe getoont, wert hooch noodich ingesien en goet gevonden, sonder lange te tardeeren, hen datelijcke inde voorweere te stellen; voor eerst alle gebouwen en woninghe soo van de Javanen ende Chineesen rontsomme 't fort te ruijneren en een wtsicht te maken, alsoo alle quaet, soo veel doenlijck was, voor comende, eer alle middelen daer toe nodich hun mochten verhindert en affgesneden worden; twelck oock ten effecten gestelt en alsoo volcht begonnen en gesuccedeert is.

1 Zie. de hierachter als Bijlage III afgedrukte resolutie van 22 October 1618. Verg. De Jonge IV p. 109. Brief Coen 12 Nov. 1618.

2 Orang Kaja $=$ aanzienlijken.

3 D. i. 22 December. De Jonge ibid. p 121. Brief Coen 14 Januari 1619.

4 Het huis Mauritius stond dicht aan de rivier, evenwijdig daaraan. 
Den 23 Desember op Sondach des morgens gemerckt synde, hoe de voorgaende nacht in de Engelsche logie, hier voorgenoempt bolwerck gemaeckt was, als oock mede dat int Chineesse quartier menichte van huijssen wierden affgebroken en een baterije achter tegent oudt huijs Nassauw begonnen waeren, onstonden daer wt bij de onse veele bedenkingen, datter niet goedts moste voorhanden sijn, waer over den $\mathrm{H}^{r}$ Generael alle het volckt int fort in werck gestelt, ende alles slachtvaerdich te maecken, gecommandeert heeft, en tgene noch niet geheel voltrocken waere, claer te maeken. 't Fort aen de landtzijde noch een stuck weeghs open sijnde, wert met palassaden inder haest geslooten; de woninge van smits, cuijpers, blockmakers ende swerten, die noch stonden buijten $t$ begrijp des fort, hoe wel binnen de heining, wierden geraseert, om door den brant geen schade subject te sijn. De see punt ${ }^{1}$ is met eenen houte cappe overtogen; de catte, ${ }^{2}$ noch gants reddeloos leggende, door dien van buijten boven 9 a 10 voeten niet opgetrocken was, is metter spoet sonder calck opgelecht met resterende corrael steenen en $2^{3}$ halve cortouwen in de affuijten gelecht. Twee ${ }^{+}$stucken wierden geplant aent oosteijnde en beneden $t$ huijs Nassauw aen de pagger door dien noch geen punt en hadde; oock eenen ter zijde de catte ${ }^{5}$ om in noodt mede te flanckeren langs $t$ selve oudt huijs.]'s Daeghs te vooren waeren de Javanen en Chineesen meest opwaerts de riviere vertrocken, en diegene noch overich waeren hebbe haer op dato mede in haeste derwaerts vervoecht. De Javanen onderstonden de ledige en verlatenen Chineessen woninghen te plunderen $;{ }^{6}$ d'onsen hebben eenich sout wttet selve quartier, dat haer toe behoorde, gebercht; oock ontrent 4 leggers arack wt Wattings ${ }^{7}$ huijs

1 D.i. de N.O. punt.

2 De kat of hooge batterij werd opgeworpen tusschen de haaks op elkander staande pakhuizen Nassau en Mauritius.

s B I zegt "metalen".

"Bij BI "sware isere".

- B I spreekt niet van de kat, maar zegt: „brachten oock een stuckx bij de bottelarij" met hetzelfde doel. De bottelarij lag dus aan de westzijde in het huis Nassau.

- Van het begin tot hier komt de tekst, op enkele woorden na, met BI overeen.

7 Watting was, zooals verder blijkt, een rijke Chineesche handelaar en reeder. Zijn huis lag in het Chineesche kamp, nabij de rivier, bezuiden het fort, op den rechteroever. 
becomen met eenigen verlaten bocken. De Coninck, deze haeste resolutie merckende, heeft sijnen verscheyden spien wt gesonden om alles te vernemen en te besichtige; dan en mochten niemant binnen het fort inne gelaten worden. Quiaij Area, ${ }^{1}$. eene van de voornaemste vechters beroemt, heeft hem soo lange ontrent het fort gehouden als conde, tot dat hem expresse belast is te vertrecken oft anders in swaricheijt soude geraecken. Ondertusschen eenen yder alsoo besich was int werck, is den raedt bij den $\mathrm{E} . \mathrm{H}^{\mathrm{r}}$ Generael vergadert, en naer dat bij den selven was geproponeert, hoe nu apparentelick waere, beyde den Javaen en den Engelsman, die oock weijnich dagen te vooren den Swerten Leeuw int gesichte van Bantam verradelijck hadde aengehaelt ${ }^{2}$ en tot geenen restitutie en wilde verstaen, daer door genoechsaem een generaele oorloge gecauseert en aengevangen hadde, eendrachtich sijnde, gesint waeren de Nederlanders wt dese quartieren soo 't haer doenlijck was te verdrijven en daertoe alreede seer sterck en wel veerdich waren, zij lieden des halven soo gesint waeren de plaetse te behouden, genootsaect waeren datelijcken de vyanden te prevenieren en hun begonnen werck te verhinderen, en hun rontsomme een wtsicht voor eerst te maken, tsy door brantstichtinge ofte anderen middelen, naer dat de gelegentheyt soude presenteren. Ende eendrachtelijck goedt gevonden zijnde, de plaetse inde name des Heeren, t zij met ofte tegen de wille van partij te behouden soo lange als immers doendelijcke soude sijn, wiert geresolveert den vyant, die nu al vaerdich was om den eersten torn te doen, voor te comen, en den eersten slach te geven tot welcke fijnne des namiddachs Jaques Le Febre ${ }^{3}$ in de Engelse logie aen Niclaes Ufflet ${ }^{4}$ is gesonden, begerende wt den naeme vande E. $\mathrm{H}^{\mathrm{r}}$ Generael, dat de opgeworpen batterije datelijck mochte affgeworpen en geslecht worden, ofte anders daer selver in soude versien, $\mathrm{t}$ welck bij de Engelsche wiert gerefuseert, voorwendende tselve niet bij hem, maer door den Coninck van

1 Kjai aria. Kjai Jav. titel voor bejaarde mannen; Aria, skr. achtenswaardig, achtbaar, alleen in titels.

215 December.

s B II zegt: „omdat hij wat engels conde".

4 Nicolaas Uffelet, koopman van de Engelschen. Res. Coen en Raden $10 \mathrm{Juli}$ 1618; zie o. a. V. d. Chijs, De Nederlanders te Jakatra, Amsterdam 1860 p. 23. Bij Purchas his Pilgrimes, Glasgow 1907. Dl. XX, Index p. 400, komt hij voor als Nicolaas Ufflet of Uphet. 
Jacatra gemaeckt waere, en derhalve sulckx haer tot diffentie dienende, niet gesint en waere, noch in hun vermogen stond tselve te ruijneren. De sommige wierpen voor, den selven Lefebre vast te houden, dan en is niet aff gevallen. Soo haest Lefebre vertrock, sijnder eenige Javanen gewapent in de Engelse logie wt de stad gelopen, wel vermoedende wat sonders op handen waeren. Ondertusschen was par ordre van de $\mathrm{H}^{r}$ Generael alle het volck in de wapenen gestelt en een ijder belast op het sijne te passen, en hen op de gedaene loose van clock geluijdt alsoo te houden alst behoorde.

De Chineesen woningen aen de zuijt zijde ende de Javaense aen de oost zijde vant fort wierden in haeste door $\mathrm{P}^{r}$ Dircxse en Pieter van den Broeck in den brandt gesteecken ${ }^{1}$, ende.op terstont van de rivier punt, alsoo de catte noch ongereddert was, 5 grove stucken op d' Engelse batterij en logie gelost, en is op Pieter van Rey en den luijtenant Abram Jansz Morincx ${ }^{2}$ met 30 mosquettiers in de boot ende schuijte gevallen, zijnde d'Engelsche batterije ende logie bestormt, geentert en de vlagge affgehaelt sijnde, in de brandt gesteecken; doch en wiert het Javaens ofte papenquartier liggende zuijdelijck ${ }^{3}$ neffens de selve logie niets beschadicht, twelck een groote versuijmenisse geacht is, alsoo daerom seecker baterije, bij de Javaen mede op geworpen, veele aen gelegen was.

D'Engelse, niet seer gemant zijnde en noch geen geschut vaerdich hebbende, sijn terstont gevlucht, doch wert int eerste eenige resistentie van de Javaenen gedaen, dan en conde niet bestaen. Van de Javanen werden 2 dooden aldaer gevonden; van onse was gebleven eenen Hendrick Jansz bosschieter. Ende also sulcx geschiet was eer d' onse met de boot over de rivier gelant waeren, en dat door seeckeren schooten met mosquet

1 B I zegt: „Pieter Direkxsen ginck naer het Chinesse quartier en ick met partij volck in Javansse daer het graf ken noch in was, die mijnden dat het geckernij was, dan soo hast gewaer wirde mijn ernst was, is met sijn volck tlandewaerts int boot gevlucht, soo dat datelijek rontom alle Javansse ende Chinesse huijssen ronsom onsse logi in brand stonden". - B II: „Ick met mijn Quartier stack het Graven Quartier in brandt; Pieter Diresz het Chineesche". Het Graven quartier, de kampoeng van Kjai Aria lag dus ten Zuidoosten van het fort.

2 B I en B II zeggen Pieter van Raey en Lefevre.

s Een vergissing, bedoeld zal zijn "noordelijk"; de batterij lag toch aan het zeestrand. BI en B II verbeteren dit.

Dl. 73 . 
wt de stadt gedaen werden, hebben d'onsen oock begonnen met het groff geschut op de stadts catte ende walle te speelen, ende op die van de stadt oock hun beste met wederom te schieten hebben gedaen.

Den brandt ondertusschen in de omleggende quartieren was soo heftich, dat niettegenstaende de wint t' onsen voordeele was, hadden nochtans de heyningh van $t$ fort oock begonde aen te gaen, dan wert tijdelick geblust. $\mathrm{t}$ Schieten aen weder sijde continueerde dien geheelen dach tot in den avont, beloopende ontrent van onse 70 ende van de Javanen 40 scheuten. ' Verlooren dien dagh noch 4 man, te weten Gerrit Dircxse, smit, Claes Adriaensen, bootsgesel, ende 2 negros, en hadden noch 7 gequesten. Alsoo is Godt betert den oorloge aengegaen. Godt geve geluckich succedeeren.

De standt ende gelegentheijt vant fort en de stadt Jacatra was dus danich: ${ }^{2}$

De stadt Jacatra is gelegen dwers over de riviere, suijdelijck ten Westen van $t$ fort, en was langs de riviere met nieuwe wallen voorsien; daerinne stondt een hooge catte, beplant met $5^{3}$ stucken schuts. Hadden oock verscheyden ${ }^{4}$ stucken beneden in de wallen gestelt, daer mede om de nabijheijt groote schade deden. Buijten de stadt mede aen de oversijde de riviere aende hoeck van de seecant west ten noorden van $t$ fort was mede een sterckte, bij d'onse genaempt paeps Jans ofte papebaterije. Daer op stonden 2 stucken met een basse, waermede de wt-

1 B I "sohooten over de 40 schooten op ons, dooden 3 duijtssen met 2 swerten en 10 gequedts waer van naderhant noch 6 sturven. Den tweeden schoodt, die daer van de Javanen geschooten wirde, was naer de poort, daer ick met ontrent 30 man stond ende den schoot vloch onder de sollen van onssen huystimmerman genampt.... sonder hem te beschadigen en int wederom verheffen bayde de hiellen van een coopman Joost Grendel die dicht aen mijn syde stond die datelijek onder de voet gevallen is, voorts vlooh denselven cogel een soldaet int dick van een soldats been ende daer naer inde door vande poort."

2 B I „De gelegentheijt vande Loogie ende stad Jaccatra soo voor den orloch bij mijnen tijdt waeren.

De stadt Jaccatra is gelegen op de hoochte van 5 graden 57 mijnuten op het eijlant Java ontrent 12 mijlen van de stadt Bantam".

- B II zegt: 7.

- B I ,engelse". 
vaert ende het incomen van de riviere hinderlijck waeren en oock de strandt noordelijcken het fort gans periculeus en onveijlich hielden ${ }^{1}$. Binnen de stadt wert geestimeert te sijn ontrent 6 a 7000 man, dewelcke nader handt door de Coninck van Bantam noch meerder sijn geworden.

F t Fort hadde het nieuwe huijs Mauritius aen de west ende het oude huijs Nassauw aen de zuijtzijde tot gardijnen ${ }^{2}$; was voorts noordelijck aen strandt ende oostelijck aen t bosch sijde met aerde gardijnen ${ }^{3}$ ontrent de 9 voeten hooge ${ }^{4}$ omslooten; hadde drie punten. De catte stadtswaerts aen $t$ Zuijt eijnde vant huijs Mauritius van corraelsteenen begonnen en inder haest voorts opgeleijt, was met loose bedinge besorcht, hooch ontrent 16 voeten, en daerop 2 halve cartouwen ${ }^{5}$ doch sonder borstweringe en gants onvry en open. De rivierpunt, liggende noordelijck aendt huijs, hadde beddinge hecht en vast, doch maer twee voeten boven d' aerde verheve, en was met ${ }^{6}$ swalpen rontsomme voor aenloop en in plaetse van borstwering affgeschut, en niet bestandich voor een scheute met mosquetten. Daer op stonden 7 goede stucken ${ }^{7}$. De noort ${ }^{8}$ ofte zeepunt was opgetrocken in gelijcke hoochte als de gardynen, en met pallassada voor borstweringe omstelt, en boven voor de regen met een houte dack bewrocht ${ }^{9}$; hebbende mede 7 stucken

1 B I: , corts te vooren eer den orloch aenginck hadden de Javannen de revier van d'een sijde tot d'ander int incommen met clappes boomen toegehaijt, datt er qualijck een boodt uijdt oft in conde commen".

Gordijnen of courtines, de rechte wallen tusschen de bastions.

- BI: "tussen pallisaden inder iijl opgemaeckt".

"BI: "en 8 voeten dick".

- B I: "2 metale halve cortouwen 3 heele sackers".

- B I : „dubbelde swalpen”.

7 B I: ${ }_{n} 7$ stucken geschudts, 2. metalle halve courtouwen ende 5 ander sware sackers."

8 B I zegt terecht "noordtoost".

- B II: luidt: "voor den regen om met muschete gestadich te mogen flanckeren. In tijden van noodt lagen mede 7 stucken geschudts dan niet soo swaer door den banck als d'ander, omdat het de punt qualijok lijden mocht ende hem somtijds op sommighe platsse begaff. Aen de oostsijde was noch geen pundt allenelijck een oude galderij vant huijs, die met swalpen tot borstweringen versien wirden, om met muscheten des noodt sijnde lanckz het oude huijs Nassouw te mogen flanckeeren". - B II zegt: "Alan de noord-oost [lees "zuid-oost"] zijde was noch gheen punt (dat noodich was) begonnen, dan alleenlijek een pagger van bamboesen aen het huys Nassauw, en een galderij daer met musquetten van konden flanoqueren". 
geschut. Aan de oostzijde, en was noch geen punte begonnen, dan alleenlijcken een gaelderije aent oude huijs Nassauw, daervan met mosquetten langs de gardijne flanqueerden, en alsoo eenige tegenweer conden doen. De gardijnen waren boven ontrent 6 a 7 voeten breet en gants sonder borstweringe, alsoo dat niet eenen man daerop conde zijn ofte conde van de vijandt besichticht worden, doch is daernaer door grooten arbeijt en perijckel meer en meer versterckt geworden.

Adij 24 dito des morghens geheel vroech sijn van s Coninckx bolwerck 4 schoten op t'fort gedaen, waerop terstondt rescontra geschiede, $\mathrm{t}$ welck alsoo dien geheelen dach tot den avondt is gecontinueert. Door Pieter van Reij is met ontrent 20 soldaten eenen wttocht - gedaen om $\mathrm{t}$ werck, dat den Javaen achter t'oude huijs Nassauw in Wattings huijs gemaeckt, te besichtige, daer op ondertusschen 3 scheuten van oostelijck benedenstucken wieren gedaen - verricht. De catte, noch sonder borstweringe synde, en seer periculeus omme de stucken te gebruycken, wert met schanskorven, linnen sacken en packen cleeden ${ }^{\prime}$ in haeste wat versien, en $t$ volck wat meerder beschut, sijn oock eenige stucken den vijant onbruijckelijck gemaeckt, maer werden in corten weder herstelt. Op d'onse is oock seer constelick geschooten, soo dat sekerlijck presumeerden Engelse bosschieters aen landt gecomen waren. Wert insonderheijt seer geschoten op de catte, den camer van de E. $\mathrm{H}^{r}$ Generael, $t$ nieuwe huijs en den toorn. Men dreijchden oock eenen wtval te doen op paeps Jans batterye, maer en is dien dagh niet affgevallen. Wiert oock geoordeelt dese twee dagen $t$ vierde paert van $t$ cruijt verschooten was. Tegen den avondt isser een Chinees in een praeuw verbij ' $t$ fort comen varen, seer jammerlick roepende, dan alsoo hem niet conden verstaen, is van de schiltwacht doorschooten. Denselven eenen man verlooren, genaempt Roéloff Fredericxse, soldaet ende eenen genaempt Jacob van Middelborch, bosschieter, verloor sijnen slinker arm bij foute van ons eigen geschut aenginck, en niet wel gelost en waere" 2 .

I BI: " schanscorven, lijwatte paoken, eleeden van de ouste Cormandel in der haste".

- Deze bijzonderheden zijn bij B I weggelaten, evenals de excursie van Pieter van Raey. Ingevoegd is: „Denselven middach maeckten mij den E. Heer Gen ${ }^{\mathrm{al}}$ Jan Pieterssen Coen Cappitïn Majoor van t fort ende crijssolck, dat geen waijnich invidi onder de cooplieden ende ander causeerde. S avons bevont datter twee. Hollanders van den vijandt met groff issers gesohooten waren." 
Adij 25 dito Corsdagh ' s morgens vroeg wert gecommitteert Abram Jansz Morincx, luytenant, met 30 mosquettiers om op de voorn. baterijen van paep Jan over de riviere op de hoeck van de seestrant eenen tocht te doen; d'onsen int aenmarcheren liep de Javaense voorwacht onversiens op t lyff. Van de seepunt wieren op de selve 3 stucken gelost; d'onse chargeerden, daar op de Javaen int eerst aent wijcken waeren. Dan, alsoo de voorste geleden aftrock, van meijninge omme andermael te laeden, meijnden de reste, meest onbedreven en jonge soldaten zijnde, datse de vluchte name, oock doordien de bequaemste passagie hun alreede affgesneeden was, zijn geretireert en door geloopen;

1 Kerstdag. Deze uitval geschiedde dus op 25 Dec., zooals Coen (De Jonge IV p. 122) mede aangeeft, en niet op 24, zooals Van der Chijs uit B II, waar de datum weggelaten is, afleidt. B I zegt:

„Den $25^{\circ} \mathrm{d}^{\circ}$ 's morgens was ick van den Heer Gen ${ }^{\mathrm{al}}$ geordonneert met 30 soldatten, waerover den luijtenant vant fort commen soude genampt Abraham Janssen om te gaen over de rivier ende sien do batterij ven den Paep op den hoeck van de rivier in te nemen. Dan, omdat ick den heelen nach gevisionnert hadde de catte met starek en segorre borstweringhe te versien, was den voorsz. luijtenant ondertusschen int criecken vanden dach bij den Heer Generael geweest en aen hem seer instantelijck versocht dat alleen mochte gaen, omdat ick mode van de wacht soude wesen, hetwelok hem de E. Heer Genal consenteerde sonder mijne wette. Ick van boven commende mijnde de soldaten in slachorder te stellen om te gaen, vont dat all gereet waeren. Den luijtenant daerover geroepen hebbende, belasten dat een oogenblick wachten soude, ginck mij gereedt maeken; gecft mij ten antwoordt, ick hem geliefde te excuseren, dat de E. Heer Genal hem vergundt hadde op sijn versoeck dat alleen soude gaen. Infien is datelijok met een boodt over gevaeren ende sonder eenigh resoontre tot in de baterij van den vijant gemaroheert, die haer doen eerst gewaer wirden en hun terstont te weer stelden. De soldaten in ' $t$ eerste gelidt, hun muschetten op den vijandt geloost hebbende, retireerden haer volgens de usantie om d'ander plaets te geven; die achterste onervaeren soldaten zijnde, mijnden dat de vorste lieppen, wierpen haer geweer neder en stelden op een loopen, daer op de Javannen moet ende coragie namen sijn met een furij op d'onsse aengevallen, naer datter 5 a 6 van haer doot lagen ende de meste part gevlucht, velden den voorsz luijtenant met een pieck ter neder ende noch een lijffschudt van den Genal Coen genampt Davidt Parre adelborst, voorts noch 6 van d'onsse derlijek gequedts waervan 4 naderhand, te weten 2 Hollanders en 2 Jappanders, gestorven sijn; d'ander twee bequamen, goddanck, wederom.

Infien hebbe (godt almachtich) genocht te danken, dat met sulcken onervaeren sodatten niet ten krijgh gegaen en was. Ontrent de middach stacken de Javanen de hoofden van den luijtenant ende adelborst Davidt Parre op bambossen ende settensse op den hoeck pundt recht over de catte van onsse deftighe starckte, doch namen deselvighe 's anderdachs wederom aff en wirpense in zee", 
daerop den Javaen, hem te meerder te weerstellende, d'onse vervolcht en sommigen aff geslagen hebben. Verlooren de Javaenen na extimatie ontrent 5 a 6 man en d'onsen lieten achter den luijtenant voorn. en David Peru adelborst, sonder oock de doode lichamen onderstonden met hun te nemen. Waeren dootlijck gequest 4 persoonen, 2 Nederlanders en twee Japponders die oock mede naderhandt overleden zijn. Ontrent anderhalff ure naer dese hebben die van de stadt de hoofden van voorn. luijtenant en adelborst neffens haer punt, ontrent een slingerworp vant fort, op staecken opgericht, doch sanderdagen smorgens vroech weder aff genomen ende in de riviere geworpen.

$\mathrm{t}$ Schieten op $\mathrm{d}^{\circ}$ is niet soo continueerlicke geweest als in de dage voorleden. Oock ist Jacht de Jager in salvo van Jamby gearriveert geladen met 1200 picol peper ende oock de smack met ontrent 70 picol.

Denselven [dag] bij den $\mathrm{h}^{\mathrm{r}}$ Generael ende raedt geconsidereert zijnde, in wat swaricheden alrede gevallen en welcke noch aenstaende mochte zijn, doordien beijde Javaen en Engelsman daer op wt was het fort te ruijeneeren ende $\mathrm{E}$. Comp $\mathrm{C}^{\mathrm{a}}$ te beschadigen, soo vele conden, en de schepen aen d'eijlanden Onrust met weijnich volck en gants onversien laegen; de baterije van paep Jan van de Javaenen behouden was; de riviere mochte verleijt ende afgesneden werden; groote schatte beyde inde schepen en fort waeren berustende en wat dies meer waere; is geresolveert de scheepen, soo haest geschiede conde, voort fort ter reede te onbieden, en bij provisie de princepaelste goederen daerinne te schepen, siende voorts wat de tijt soude leeren. Daertoe gecommitteert zijn $\mathrm{S}^{r}$ de Carpentier, Andries Sourij, $\mathrm{S}^{r}$ Pieter Dircxse, oppercoopman, om 't selve den cooplieden en schipperen beneffens andre swaricheden als doen meerder geproponeert, voor te dragen en advijs te vernemen. Wert oock geresolveert de $\mathrm{H}^{\mathrm{r}}$ Generael hem selve op de schepen soude transporteren om met couragie en goede ordre d'Engelse wederstant te doen. De Javanen hebben noch een nieuwe baterije gemaeckt suijdelijck het fort neffens Wattingshuijs aen dees sijde de riviere, 't welck niet tegenstaende daerop verscheyde scheuten deden, het niet verhinderen conden ${ }^{1}$.

De tijdinge van de aengevangen oorlooge tot Bantam comende,

1 Volgens Hulsebos' verklaring bij zijn verhoor, lag deze batterij wel + part nader ąan hẹt fort dan de eẹrste. 
heeft hem den Coninck aldaer sulcx seer aengetrocken, achtende 't selve aen hem oock gedaen te sijn; sustineerende, soo de victorie van de Hollanders tot Jacatra bevochten werde, het hem en Bantam ten laesten soude geven; daerom oock resolveerde eenich volck tot assistentie te senden, eer selve in sijn landt d'oorloge subject was, versochte verscheijden male d'onse tot paijse en 't affbreeken van de bolwerken voornamelijck degene, die stadtwaerts lage, wilde verstaen; sweerende anders 't selve selfs te onderstaen en te wreecken, alle zijne macht daeraen wagende, opdat niet naderhandt een quader hadde te vreesen. D'Engelse, niet minder als den Coninck de brandtstichtinge ende 't verlies van hunne logie gehoort hebbende, hebben alle middelen voorgewent om, revenge te mogen becomen; ten welcken fijne tot verscheijden reijse aen den Coninck aldaer ligentie versochten, onse logie tot Bantam te mogen aentasten ofte in de brant te steken; dan en wilde de Coninck daertoe geen commissie geven. En sijn oock al met ontrent 300 man op de beenen en rontsomme de logie geweest, om t selve werck $t$ effectueren, maer wert van den Coninck verhindert. En alsoo donse inde selve logie seer swack van volck en derhalve niet machticg waeren hen tegen haer te deffendeeren, versochtense aen den Coninck, haer wilde in sijnne protectie nemen, hem belovende de saecken ten besten gecomen sijnde, tot sijne nadeele niet en soude strecken; $t$ welck de Coninck hen belooft hebbende, heeft terstondt Henderick Jansz, ${ }^{1}$ Abram van Uffelen, Jaques Coetely ${ }^{2}$ voor hem gecompareert sijnde, $t$ geweer doen afleggen en voorts soo lange gehouden totdat voorts alle het geweer van de Hollanders wt de logie gehaelt en int hoff gebracht is, seggende sulcx alsoo te behooren, soo sij wilde onder sijnne bescherminge schuijlen, verscheyde male hun dreijgende, soo tusschen het fort en den Coninck tot Jakatra geenen peijs getroffen wort, $t$ selve met alle sijn macht wilde wreecken en vergelden. Hij heeft oock terstondt de logie met sijne wachten doen besetten, soo datter niemandt noch wt noch in en mochte, sonder sijn weten en believen, soo datse daer alle genoechsaem gevangen en alle in sijnne hande stonden. Die vant fort hebben t savonds onderstaen

1 B I zegt: „Hendrick Janssen oppercoopman in Patanien geweest en met veraet van de Engelssen op den Swarte Leuw genomen.

2 In het eerst uitgegeven dagregister, De Jonge IV p. 147, wordt hij (1 Febr, 1619) abusievelijk Jacques Cortele genoemd. 
den brant te stichten inde huijssen neffens paep Jans baterije, doch wert van de Javaenen terstont geblust.

Adij 26 dito 't Jacht Hollandia op de rede leggende heeft door ordre van den $h^{r}$ Generael aengehaelt 2 chinese joncken, die aldaer geanckert lagen, toecomende Watting, chinees. Bequamen daer wt 15 Chineesen ende een vrouw ${ }^{1}$, welcke oock int fort ende aent arbeyden gestelt zijn, met belofte ter gelegener tijt weder soude mogen vertrecken. Wert daer niet sonders gevonden dan alleenlijck een weynich was en swavel. Dese dach is van beyde sijden niet geheel veel geschooten, te meer vant forts sijde, omdat seer besich waeren met eenighe borstweringe en alle sints schootvrij. te maken.

Adij $27 \mathrm{~d}^{0}$ wert alle het volck int fort gemonstert ${ }^{2}$ ende in vier sergantschappen verdeelt, daer van de helfte soude haere corte garde $^{3}$ hebben opt huijs Nassouwe ende d'ander helfte opt huijs Maurittius, om also in ordre en allesins gereet te sijn tegen den aenloop der vijanden, die onstaen mochten. Gevonden sterck te sijn 240 geweir dragende persoonen, te weten 160 Duijtsen, 80 swerten, soo Christenen als mooren ${ }^{4}$ en heijdenen, ende in alles groot en cleijne met vrouwen en kinderen ontrent de 350 sielen.

Dien selven dach wert wederom een Chinese jampan aengehaelt, daer wt 5 Chineesen bequamen, die alle mede beneffens d'anderen, int fort gebracht ende aen 't aert dragen geordineert sijn. Men begon oock op $d^{\circ}$ de seepunt met eerde op te vullen, sijnde sulckx heel noodigh om den vijants baterije op Paep Jans meerder affbreuck te doen; de catte wiert met een houte cappe voor vier en regen bedect, en andre wercken meer wierden, soo ver als mogelick was, gevordert. De schepen aent eylandt Onrust dede mede vast alle neersticheijt om op stroom te geraecken, d'eene d'anderen getrouwelick helpende.

Van de onsen is altemet een schoote op Wattings bolwerck

1 Dit zijn de 16 Chineezen, van welke 'Hoetink spreekt; zie p. 348 van zijn meergenoemd opstel.

2 B I zegt: "gemonstert ende in twee troepen verdeelt, daer van de helf op het oude huijs Nassou ende d'ander helf op thuijs Mauritius ordonerde; over d'een helf commandeerde iok ende d'ander helft den oppercoopman Carpentier".

- Corps de garde, wachthuis.

- BI voegt in: "die noodt haẹr leven geweer gehandelt hadden", en lạat weg „heijgdenen", 
gedaen, op hoope hun het wercken te verhinderen, dan dede weynich baets, dewijle de nacht haer beter was dan den dach. En alsoo de Javanen ontrent 7 oft 8 dagen voor den oorloge de riviere met paelen beslooten hadden ende die van 't fort daer door verhindert conden werden bequamelijck haer goederen wt te schepen, hebben 't 'savons in stillicheijt en perijckel de selve geopent ende de paelen wt getrocken ${ }^{1}$. De Javanen, geruchte horende, hebben te laesten 3 schooten gedaen, dan niemant geraect, soo dat se vertrucken; doch was soo vele gedaen, dat in ' $t$ wt en in vaeren geen verhinderinge van naute meer en hadde. Ende alsoo verstaen wert, d'Engelse met alle hun macht gesint waeren van Bantam na Jacatra te vertrecken om alle de schepen van de Hollanders aen te tasten ende te ruijneren, en sijn noch geen goederen in de scheepen gebracht, te meer omdat oock de scheepen met costelijcke scheepen ${ }^{2}$ waeren vervult en men oock niet sekerlijcke conde oordeelen, waer het cappetael best soude versorcht sijn en nodich was d'Engelsche tegen te gaen. Den selven sterff Joost Grendel, ondercoopman, den 23 gequest zijnde, ${ }^{3}$ ende Tomas Claesz. huijstimmerman, mede den 25 aen paep Jans baterije gesteecken sijnde.

Adij 28 en 29 isser van beyde sijde weynich geschooten, dan elck hielt hem vast besich sijn plaetse te verstercken. Na den middach sijn onse ${ }^{4}$ schepen op de rede voort fort vant eijlant Onrust gecomen in sulcke haest, dat daer soo aen lant als int water gelaten hebben 8 stucken geschuts, ontrent 20 anckers, 200 swalpen ende goede partije sapponhout, ${ }^{5}$ twee touwen en een groote menichte cromhouten, eenige plancken ende ander rommelinge meer; oock de groote galeije, $t$ jacht de Halve Maen ende een Javaense jonck, voor Japara verovert; welck galleije en jacht corte daer naer van d'Engelse verbrant, t geschut genomen en aen den Coninck van Bantam verschoncke is. Savonts zijn oock 11 engelse schepen int gesichte van Jacatra

1 Van der Chijs p. 61 zegt, dat dit opruimen der palen geschiedde op een niet bekenden tijd tusschen 25 en 29 December, en Camphuis meldt den datum niet.

"Sohrijffout, bedoeld is "waren".

3 Hem waren "beyde de hielen", door een vier pondskogel afgeschoten.

- B I voegt in: 7.

- Sapanhout. De schepen kwamen ten $29^{\text {rten }}$ 's middags ter reede even als de Engelsche. Verg. De Jonge IV p, 125. 
gecomen, en aldaer dien nacht geanckert. De vrienden van Bantam hadden sint het nemen van de Swerte Leeuw alle tijt prauwen in de Strate van Sondae gezonden, om de scheepen van het vaderlandt van de aengevangen oorloge $t$ advijsseren, dan is daer naer van den Coninck van Bantam verboden geworden, soo dat geen prauwen meer becomen en conden. Des avonts ontrent den 10 uren heeft de vijant van sijn catte wt de stadt 3 onversiensche scheuten gedaen, daer van d eene ginck recht door de camer ende de gewoonlijcke sitplaetse van de $\mathrm{E}$. $\mathrm{H}^{\mathrm{r}}$ Generael; d'andren tegens onse catte, daer van twee man gequest wert. Van dese tijt aff werden van de Javanen geen meer perticuliere scheuten gedaen, maar schietende, loste alle hun stucken gelijck, en onderhielden dan een goede wijle; alsoo tot 3 a vier male daegs, en overmits de gemeij[n]licke gebeurde, |ter tijt als men de gebeden deden ofte aen de maeltijt saten, wert geordonneert de clocke niet te luijden, en door een ander teecken $t$ volk tsamen te roepen.

Adij 30 dito sijn sommige scheepen sonder ordre en advijs t seyl gegaen om d'Engelse tegen te loopen, maer sijn, soo door contrarij wint en een scheute vant fort gedaen, wederom geanckert. Bij den raedt overdacht synde, niettegenstaende op 25 gearesteert was, in gevalle de saken ten quasten wilde, $t$ volck en alles naer vermogen te lichten en fort te verlaten, om des te stercker d'Engelse te mogen rescontreeren; wat quaet en diseere wt hetselve soude mogen ontstaen, van ydele drygementen sulcx aen te gaen, en wat aen te mercken. Doen voorgestelt ende gedelibereert wert, is geresolveert d'Engelsche schepen naerder te verwagten en ondertusschen een tocht op paep Jans baterije te doen, om den vijant van daer te slaen, de riviere vry te maken, om soo des noodich waere, de goederen bequamelyck wt te mogen voeren. Dan wert door sien comen en naderen van d'Engelsche scheepen verhindert, gelijck ook des Comps goederen ende het volck te lichten; soodat genootsaect waere de saecke over een ander sijde te wenden. Wert derhalve, ook te meer de wijle d'Engelsche de bloetvlagge wt gesteecken hadden, geresolveert, dat de geordineerde van 25 dato haar ijder in haer schepen soude transporteren om d'Engelse te rescontreeren, soo als den tijt dan soude leeren ${ }^{1}$. En omme het volck des te

1 B I vervolgt: „Ende om het volek vant fort ofte loogie dies te meer in ordre ende couragi te houden wirdt den Radt andermael vergadert om wie 
meer in ordre te houden en te couragieren, werden tot overhoofden gestelt en geauthoriseert Pieter van den Broeck, commandeur, Pieter van Rey, Jan van Gorcom ${ }^{1}$ capp $^{n}$, Abram Strycker, luijtenant, gevende met eenen d'E. $\mathrm{H}^{r}$ Generael int openbaer te kennen, hoe hem nu d'Engelsen vijant van de vereenichde Comp ${ }^{a}$ hadden verclaert en derhalven gants nodich en goedt gevonden ware, hem selve $t$ schepen te begeven om den standt van de Compa naer vermogen te secoureeren; ende maende oock alle omstanderen, haer als getrouw en vrome lieden cloeckelijcke haer devoir te doen, en alles ten beste comende, haer soude met goede avanse bedencken; daerop eendrachtelijck geroepen wert, daertou seer wel gesint te sijn, wenschende alsoo met eenen malcanderen geluck en voorspoet. Den $\mathrm{H}^{\mathrm{r}}$ Generael, alsoo sijn affscheijt nemende, is des avonts vergeselschap met Pieter de Carpentier, Andries Sourij, Jaques Lefebre, Pieter Dircse en ontrent 20 matroosen met hem, en dat secretelijck [vertrocken] sonder de Javaen ergens affwiste.

Op dato zijn door den Coninck van Bantam tot assistentie van de Coninck Jacatra gesonden en vertrocken 4000 Javanen, daer beneffens noch 8000 gereet gemaeckt werden, omme des nodich synde haestelijck te enbarqueren; de Coningen alsoo rondelijck gesint sijnde, de ruijne vant fort te beneerstigen, niettegenstaende het oock sonder haer selffs groote schade niet en conde geschieden.

Adij ult ${ }^{\circ} \mathrm{d}^{\circ}$ 's morgens ontrent 2 uren voor dach is noch wt het fort versonden een boot met 4 kisten contant, om int Jacht Cleen Hollandia gescheept en naer Amboijna versonden te worden. Den Javaen, 't gerucht van wt varen hoorende, hebben 2 schooten van paep Jans baterije. daernaer gedaen, doch niemandt geraect. Van de onse is wederom van gelijcken geschiet.

voor hooft op het fort in apsentie van den E. Heer Genal soude blijven.

Infien wirdt bij de EdelHeer Gouv ${ }^{r}$ Gen $^{a l}$ Jan Pieterssen Coen ende den presenten Raedt goedgevonden, dat ick voor commandeur ende overhooft met den oppercoopman Pieter van Raij mijn segonde persoon, ende den -sturman van den Gouden Leuw voor cappitijn over de soldaten soude blijven, soodat de E. Heer Genal voor sijn vertreck mij noch voor Commandeur, Pieter van Ray voor oppercoopman en Jan van Goreum voor cappitijn ende Abraham Strijeker voor luijtenant geautoriseert heeft; in oppenbahaer en idereen gevracht, oftse mij daer voor erkenning wilde sworen altsamen met mij te leven ende starven gaff, voorts de Heer Genal int oppenbaer met een deftige orasi verhalde, hoo de Engelssen" enz.

' Jan Jansz van Broekom of Brouckom, gezegd van Gorkum. 
Metten dach zijn d'onse met haer schepen als d'oude Sonne, ${ }^{1}$ den Engel, t Wapen van Amsterdam, Delft, ${ }^{2}$ de Goude Leeuw, de Valck ende Jaeger van de reede voor Jacatra onder seijl gegaen ende naer d'Engelse vloote toe geloopen sijnde, in als sterck 500 sielen, daer onder mede sijn gereeckent de siecken vant eijlandt, ende ontrent 20 negros als Japonners, blyvende ontrent 400 hondert weerbaer mannen.

D'Engelse bestonden wt elff schepen te weten: de Mane, den Eenhoorn, de Gift, de Pepercoren, de Swarte Leeuw, de Samsom, den Touras ende ' $t$ jacht de Roos ${ }^{3}$. Daer onder waren 2 admiraels, 2 vice admiraels ende 2 schoute bij nachte. De weynichte van hun volck conde niet te weten krijgen; dan mede verstaen, datse seer swack van volck waren. D'onse liepen soo na bij den wint als doenlijck was, dan conde de Engelsche schepen niet beseylen, soo datse het een stuck weechs beneden haer geset hebben; en siende de bloetvlagge van haer sijde waeijen, hebben d'onse oock haer wt gesmeten. Ontrent 2 uren naer den middach is d'Engelse vloote ontrent een gootelincx schoote op ons affgecomen en haer merseyls gestreecken hebben, hielden bij en hebbent daer weder geset, sendende een trompetter op d'onse aff; de welcke, gehoort sijnde, eyste wt den naem van d'admiral Thomas Dael onse geheele vloote op, op luijde in duijsche sprake wt roepende, dat d'onse haere compangie seer groote schade gedaen hadden, hun volck gevangen hielden ende van armoeden lieten vergaen; ende dat se derhalven gecomen waeren om sulcx te repenseren, ende bij aldien niet opgeven wilden, d'onse met gewelt soude aentasten; ende soo goedtwillich opgeven wilde, sy d'onse goet tractement doen, ende niemant sijne maentgelden verliesen, maer alles ten vollen betaelt soude worden. Item segt uwen Generael Jan Pietersz Coen, dat hij bij mij den Admirael aen boort comt, ofte soo hij niet comen en wilt, soo segt hem, dat

1 B I zegt: „daer de E. Heer Genal selven op was, omdat seer costelijck gelaaden-joncke van Patannen gecommen was, 't schip Delft, volladen naer't patria, enz. alt samen costelijck ende rijek geladen onder sijl met een deftige courage gegaen naer de Engelsse vloodt sijnde".

"Of „de Duyvell van Delff"? Verg. o. a. De Jonge p. 152.

3 Purchas, Ed. 1905, Dl IV p. 540 en Dl V p. 12 noemt de volgende schepen: Moone, Unicorne, Gift, Peppercorne, Swarte Leeuw, Samsom, Thomas, Rose, Globe en Bee, onder Sir Thomas Dale en Martin Pring.

B I noemt: „de Maen, de Gieft, den Eenhooren, de Samson, Pepercorn, Gloob, de Cloof, den Touras, de Roos, de Bie met den Swerten Leuw", 
hij een Jesuijt is, met veel andre onreijnde redenen meer, waer op van des Generaels wegen geantwoort, seght uwen Admirael soo hij de Swarte Leeuw niet weder en geeft, dat ons met gewelt weder revenseren sullen; is hier mede doorgegaen. Int ondergaen van de sonne isser een zeijl tseewaerts om de west gesien, gelijck mede een boot met een smackseyl, komende op d'onse aff, daer naer toe d'Engelse met verscheijde boots sijn gevaere. Denselfden wert by de punt fort een van des vijants stucken, staende op hun catte wt de zepaerden de trompe schadeloos geschoote, dan wert eerlange een ander in plaetse gestelt. ' $t$ Jacht Hollandia is naer Amboijna vertrocken met advijs van de gelegentheyt en stant de saecke ende oorloge alhier. De vrienden van Bantam hebben met advijs van den Coninck aldaer naer Jacatra gesonden Cornelis Houbraecquen, ' om met die vant fort van vrede te spreecken, te wijl bij den Coninck en oock de vrienden en Comptoir aldaer seer veel aengelegen is; doch en is int fort niet gecompareert, maer door den Coninck van Jacatra opgehouden. D'onse niet connende te sprake comende, is by advijs van de Coninck ten laesten derwaerts vertrocken.

Primo Fanuarijo, anno 1619. D'onse vermoedende, dat het gesiene zeijl van gisteren moste $\mathrm{t}$ schip Bergerboot zijn, van Jambij herwaerts comende, hebben smorgens vroeg, de wint wat landelick zijnde, haer ankers gelicht, loopende ten naesten bij dwers op de Engelsche vloote om boven wint te coomen en $t$ Bergerboot te salveren. D'Engelsse, d'onse siende aencomen, hebben oock seyl gemaeckt, en also de bovenste geen tijt en hadden om hunne anckers te lichten, hebben tot 5 toe hunne touwen affgecapt ende de anckers laten staen, loopende voor de wint naer de laeste toe. Eene van hun vice admiraels, recht door d'onse overlopende, hadde seer lichtelijck te becomen geweest, sonder dattet van de andere hadde connen belet worden, soo d'onse slechts ten rechten haere intentie hadde geweten ${ }^{2}$. D'onse cregen doen tertijt de louff en hebben ontrent den middach met den anderen bij Ontang Java geset. Op $d^{\circ}$ is

1 Cornelis Houbraken.

2 B I zegt daaromtrent: „In somma tschip den Eenhooren dat jonckx onder sijl geraekten moste per fors voor onsse schepen over loopen, soodat sydt genochsam verovert souden gehadt hebben, maer de Heer Genal wilde den eersten slach niet geven". 
oock mede $t$ fregat Zelon ${ }^{1}$ van Succedane, gants van geen swarichheit wetende, ghecargeert met een costelicke partij dijamanten, gearriveert, die oock met groot perijckel aen landt en int fort werden gebracht. Des snachs daerna hebben die Javanen de jonck van Watting, die bij d'onse den 26 aengehaelt was, in de brandt gesteecke, sonder dat bij die vant fort belet con werde. Ontrent desen tijt quam een geruchte, hoe dat d'onse in Androgierij vande inwoonders vermoort ende de compangies goederen alle geplundert waeren; doch wert naderhandt verstaen, sien een Javaens ende Engels pratie geweest is. Den selfden sterff Samel Kint, commandeur geweest op $t$ fort Geldria op Pallicatte ${ }^{2}$; wert met een goede statie binnen $t$ fort ter aerde gebracht.

Den 2 d'onse wederom $t$ schip Bergerboot $t$ seewaerts dwers door d'Engelsche vloot gesien hebbende, sijn voor de wint derwaerts geloopen; dan also t schip Delft aende grond geraecte, waeren d'onse genootsaeckt wederom te setten. $t$ Selve schip door hulpe van de andere weder van de gront gecomen sijnde, hebben wederom seijl gemaeckt, loopende beneden d'Engelse vloote naer $\mathrm{t}$ schip Bergerboot als vooren; d'welck d'Engelse siende, sijn met hun elff schepen, daer onder oock de Swerte Leeuw eene was, ontrent smorgens ten 10 uren op d'onsse affgecomen en binnen schoot zijnde, heeft den Engelsche Generael datelick met scherp, op schip d'Oude Sonne, die de vlagge voerde geschooten. Eer men wt de Sonne wederom schoot, wert een weynich vertoeff, doordien geacht noch wat te veer van malcanderen te sijn; dan alsoo den Engelsche Generael wederom te naeste bij liep, waer over d'onse, in de lije sijnde, niet nader conde comen, hebben hem van verre met scherp geantwoort, en hij wederom op d'onse schietende, deede d'anderen Engelse $t$ beste mede op onse volgende scheepen, gelijck oock d'onse deeden op haer, en is alsoo den slach aengegaen van weder zijden gereedichlijck op malcanderen schietend, gedurende zulcx ontrent 3 uren lang. 't Schip Bergerboot ondertusschen onse vlagge kennende, is naer de vloote toegeloopen,

1 B I vermeldt de aankomst van het jacht Ceylon als volgt: „Tegens den avont is het jacht Selon, door mij op de custe van Indien verovert, hier van Soccodanna met party diamanten te rede gecommen, sonder int minste van eenighe swaricheit te weten; onder de diamanten wasser een van 16 caraet".

'Samuel Kint was met van den Broecke van Masulipatam gekomen. 
alsoo dat tegen den avont bij de schepen gecomen is, seggende sijn sloepe over 2 dagen naer d'eijlanden gesonden hadden, maer in de hande van de Engelsche was gevallen. De schepen van beyde sijde sijn niet weynich getroffen. D'Engelsche scheenen niet veel lust te hebben om abordeeren, want, boven wint zijnde, dede niet anders dan aff en aenhouden. Sijn dien dach in de Hollantsche vloote ontrent 50 vaeten cruijts verschooten, sijnde een derde paert van alle tgene bij hun hadden. D'onse verlooren in de slach 8 man en hadde 15 gequeste gecregen, daervan naderhandt noch eenige gestorven zijn. Wat schade en verlies d'Engelsche geleden hebben en is niet openbaer gewerden. Des avonts hebben beyde ontrent de wal geset. D'Engelse hebben in den slach onse gevangene van de Swerten Leeuw becomen, gedwongen haer int regeeren vant schut en seijlen te helpen, stellende bij hun eenige Japonneesen met de bloote geweijre, die hun instantelicke aendreven, dreijgende soo eenichsins versuijmich ofte onwillich waeren, datelick te doorcappen ende om t leven te brengen.

Op dato is wttet fort dien dach een schoot acht of 10 op de stadt gedaen, sonder ijets in eenen dach 2 ofte 3 verricht te hebben. Den selven sterff Jacob Engelbrechtse, bosschieter, met onse eygen geschut versuijmt ende verongeluct sijnde.

Den 3 smorgens hebben d'Engelse noch 3 schepen, namentlick Jems, de Hont ende t Jacht Britten ${ }^{1}$ bij haere vloote ter assistentie gecregen, soo dats als doen waeren 14 int getal, ende alsoo d'onse maer 8 int getalle waere, soo groot als cleene, en derde part van hun cruijt alreede hadde verschooten en de rest in 3 a 4 uren, soo de strijt heftich waere, oock machtich waeren te continueren, rijcke geladen scheepen te perijckeleteren hadden; oock hun niet bestant vindende d'Engelse vloote te verslaen, eenige reddeloose ende gants onbeseijlt waeren, en oock in bedeckinge ${ }^{2}$ gebracht de groote macht vande Engelse, soo tegenwoordich als noch tot Bantam zijn, ende oock toecomende hadden, ten laeste oock omdat vande d'Engelsche vloote seer sterck vervolcht waere, alsoo dat gene gelegentheijt en hadden omme met de raden vant fort te spreecken, wat hun mede in desen swaren stant den dienst vande generaele

1 B I zegt: "de Clijne Jems, den Hondt ende tjacht Britton". (Purchas V p. 13 "the little James, the Hound and the Francois".)

"Lees: "bedenckinge". 
Comp $^{\mathrm{a}}$ geradenste dachte, zijn eijntelick geresolveert om niet geheel int perijckel te stellen, met de geheele floot naer Amboijna toe te loopen, en de ganse macht aldaer bij een te verzamen, ende met den aldereersten weder herwaerts te keren. 't Welck oock geschiet ende naer gecomen is tot groote discouragie van degeenen, die binnent fort waeren, ende den aenstaende macht vande vijanden te verwachten hebben, niet en conden retireren.

Wt de vloote is een saloupe aent fort gesonden ${ }^{1}$ met advijs van tgeene tusschen d'onse en d'Engelsche gepasseert waere, mede met ordre aende Commandeur van den Broeck de plaetse soo lange te behouden als $\mathrm{t}$ mogelick'soude zijn; den moet niet verlooren te geven, maer couragie te behouden, goede ordre te houden en stelle; eere te bedrachten; de provisie, boecken ende pampiere opt raetsaemste te bewaeren; daerbij doende in gevalle $t$ welck Godt verhoede $t$ fort niet langer en conde behouden, men soude sien met de Engelse oft den Coninck van Jacatra te contracteren, ende de pampiere tijtelick verbranden om in geene vreemde hande te geraecken; doch sustineerde beeter ware, in sulcken gevalle, t'fort aende Engelsche dan aen de Javaen over te geven; beloovende, hoe wel nu genootsaeck was innewaerts aen te loopen, met de naeste gelegentheijt $t$ haerder onset met de gantsche macht wederom te keeren.

t Vergat Ceilon, siende de vloote alsoo voorbij de reede loopen, stellende haer coers om d' oost en mede d'Engelse vloot hun naer jaegende, is sonder ordre te hebben, sijn ancker lichtende, hun naegeloopen ende in de vloote begeven, niet sonder groote perijckel de selve achterhaelt hebbende. D'Engelsche hebbent onder noordoost $t$ eylandt int gesichte vant fort geset. Op dato zijn van Bantam tot Jacatra voor ancker gearriveert 30 Javaense prauwen ende in yder 60 a 70 man, $\mathrm{t}$ welck vant fort niet conde belet worden. Den selven sterf

1 B I : „ende tsijl gegaen sijn, loopende verbij het fort. De E. Heer Genal sondt mij een sloep uydt de vloodt thoe met 8 man, 8 vatten cruijdt en een missive van sijn handt, waerin gementiont stont, watter tuschen onsseende Engelsse vloodt int cleen gepassert was; voorts ons couragie gevende met belofte, dat hij maer in der haste inwarts aen ginck om aldaer de macht te vergaderen ende ons spoedich commen assisteren". 
Cornelis Everts Span, adelborst, en $\mathrm{W}^{\mathrm{m}}$ Ley, soldaet, op 25 - pass. voor paep Jans baterie gequest sijnde.

Adij $4 \mathrm{~d}^{\circ}{ }^{1}$ met den dach hebben $\mathrm{d}$ Engelsche $\mathrm{t}$ geschut, volck ende reste wt eenen van hạer jachten gelicht; hebben 'tselve in de brandt gesteken. Scheen te comen wt vreese d'onse haer revengie noch soude soecken, ende t selve niet wel door lechey't boven $t$ water te houden was.

Bij d'onse wert andermaele in deliberatie getrocke, oftet beter waere naert fort te loopen, dan alsoo tselve te begeven ende veel lieden de monden te oopenen, oock oft het geraden was hunne scheepen te verdeijlen; sommige $t$ seewaerts om d'Engelsche hier ofte daer verspreijt te overvallen ofte te verhinderen, ende $t$ fort soo veel seecoers te doen als de tijt ende macht soude willen lijden; maer wert geresolveert als vooren naer Amboijna te loopen ende de geheele macht bijeen versamen en in haest weder keeren.

De Javaen op dato heeft wat heftiger op $t$ fort beginnen te schieten als wel in de voorgaende 8 ofte 10 dagen, presumeerende de Hollantse scheepen meest machteloos gevochten te zijn. Naer den middach sijn de Engelse van $t$ voorgaende eijlandt tseijl gegaen, ende hebbe op de rede vant fort geset tot den 12 dito. $\mathrm{t}$ Bolwerck genaempt Wattings baterije, liggende zuijdelicker achter thuijs Nassauw, nu sterck opgemaeckt zijnde, is met 3 stucken beplant, daer mede veele quaets op $t$ out huijs hebben gedaen en op den toorn, als oock met musquetten dickwils flankerende.

Adij 5 dito dootgeschoten Frans Cornelissen, $\mathrm{t}$ soonken van schipper Cornelis Fransen. ${ }^{2}$ D' onse sijn oock seer neerstich geweest haer met aerde van binnen te verstercken, siende den vijant dagelicks meer ende meer baterien en sterckten opwerpen en $t$ geschut te velde gebrachten; voornamentlick arbeijden seer om de revier punt leggende aen $t$ noorteynde van 't nieuwe

1 Hier begint het door De Jonge (IV p. 138), gepubliceerde journaal.

2 B I vervolgt: „Denselven dach liedt ick aen het bollwerck vande revier dat maer met swalpen- versien was, met aerde vollen; onder tusschen spelden wij aen weersijden met groff schudt om malcander do wereken soo veel mogelijek te verhinderen. Iok sondt twee wachhalssen van ons volck snachs naer het papen quartier aen d'oversijde van de revier omme te sien off sij de huijssen in brandt conden stecken, opdat wadt uijdt sicht mochten crijgen; staecken maer 7 a 8 huijssen in brandt, om dattse den vijandt gewaer wirden".

Dl. 73 . 
huijs hooch op te vullen, daer het geschut te vooren alleen op d' aerde gestaen ende met simpelen swalpen affgeschut hadde geweest, te meer om door de vyants baterije op paep Janshouck $t$ geheele fort gans onvrij gehouden ende dickwils binnen op d'aerde nederschooten wert, ondertusschen met groff schut somtijts op den anderen speelende, soeckende ider des anderen werck soo veel te verhinderen als immers conden. Op dato wierden door die vant fort andermael eenige Javaensche huijssen over de rivier ontrent paep Jans bolwerck aen brant gesteecken, dan en wilde naer weynich niet succedeeren.

Adij $6 \mathrm{~d}^{\circ}$ naer middernacht sagen van $t$ fort van d'Engelsche vloot een schip in de brant gecomen was, vermeynnende sommige dattet een van de Engelse schepen moste zijn, ' dat by hun gesloopt, verlaete oft andersins by ongeluck in den brant geraect; was $t$ Schip den Swerten Leuw, dat voor desen bij hen op de reede voor Bantam aengeslagen is. ' $t$ Schip hadde noch in sijn volle lading, gelijck wt Japon en Patana was affgescheept. D'Engelse hadden stellinge voorgenomen ende al geordineert 'sdaechs daeraen te lossen, maer is haer misluckt doordien twert van hun eygen volck, droncken sijnde, met de kaerse beneden int ruyme gingen om den arack vaete te besnuffelen; hebben oversulcx de wiecke $^{2}$ verlooren ende den arack laeten over al loopen, ende verbaest sijnde, lieten de kaers wt de handt vallen, en is alsoo den brant veroorsaeckt, sonder datter ijets dan alleen twelck, ende dat met groot peryckel, van schut en cruijt gesalveert conde werden; voorwaer soo 't schijnt een rechtveerdighe vergeldinge, $t$ genomen soo subytelick te verliesen. Diegeene door welcke den brant veroorsaeckt is syn rejusticeert ende aen de boegspriet opgehangen. ${ }^{3}$

Denselfden dito syn weder over de rivier naer paep Jans

1 Uit BII zou men opmaken en is dan ook door Van der Chijs p. 75 opgemaakt, dat de Swarte Leeuw in den nacht van 3 op 4 Januari verbrandde.

B I komt overeen met het bovenstaande, en zegt: „Den 6 ditto naer middernacht sagen wij van fort een engels schip in haere vloodt in brandt, verstonden naderhandt het den Swarten Leuw met sijn volle ladinghe was, diese voor Bantam met veraderij van ons georegen hadden".

2 Wieoke = zwik, prop van het zwikgat.

s Owen Bodman (21 Mei 1619 Oude stijl = 31 Mei nieuwe) tusschen Poelau Bĕsi en Krakatau. Purchas 1905, Dl. IV p. 542. 
baterye $^{1} 10$ a 12 huijsen in den brant gesteecken, doch als voore en wilde niet naer voornemen ghelucken. ${ }^{2} \mathrm{Op}$ dato onder anderen met een groot stuck in de stadt op de passaer schietende, hebben een van des Coninckx bijvrouwen dwers door int midden ontwee ende oock een ander de hant af gheschooten. Door $\mathrm{t}$ gheduerich arbeyden der vijanden van buijten, $\mathrm{t}$ welck door d' overvloet van volck en materialen seer succedeerde, wart vast ['t] fort hoe langher hoe meerder benaeut. Beyde die van Bantam ende Jacatra verboode de haere enighe brieven oft tijdingen over te brengen, alsoo dat die van Bantam ende die van 't fort in langen niet van malcanderen geen rapporten, ofte iets te weeten souden becomien, soo dat verscheyden mael hondert, 150 ende $200 \mathrm{R}$. gegeven is voor eenen brief int fort, en antwoort wederom tot Bantem te brengen. Veel mael syn de mesiven op ghehouden, oock dicwils geopent en nimmermeer ten rechten gecomen; op andere tyden wederom ghesonden, alle $\mathrm{t}$ welck syne swaericheyt causeerde.

${ }^{3}$ Adij $8 \mathrm{~d}^{\circ}$ sterf Tomas Joosten en Stuijtelingh, beyde soldaten.

1 Van hier af is het Manuseript met een andere hand geschreven.

2 B I zegt: „'Savons sondt ick wederom een Japponder over de revier om de resterende huijssen op den hoeck van de revier in brandt te stecken, daer maer 10 a 12 huijssen van verbranden, doordien van de Javanen uijdt gebludts wirden".

3 B I geeft: „Den 8 ditto wirt een adelborst genampt Hans Vervach de kin met een groff isser aft geschooten, waer van corts naderhandt gestorven is. Denselven dach wirden daer 3 schooten door de Heer Genals cammer en sijn coij geschooten, resolvierden van doen vortaen beneden metter woen te gaen omdat niet veel volckx gemissen en conden, ende 't wijnich te rade houden, alsoo alle nacht met leech waater opservierdt onsse legger vol waater te houden sijnde de Javanen op t jonckste gewaer geworden, sochten $t$ selvighe ons uijdt het verbrant Engels huijs met muschetten te beletten, dan omdat daer gestadich een partij muschettiers op verdich hilt, die wederom daer op liet sargieren, somtijds oock met een groff stuck oft twee, verlieten t selve ende stelden op loopen.

Den 9,10 , tot den $11^{\text {en }}$ ditto aen wedersijden dapper donde geweest onsse batterien te verstarcken, schooten somtijds een schoodt off twee op des vijandts batterije; al wat wij by dagh onstucken schooten, wirdter's nachts wederom gemackt ende gerepareert. Wij waren daerenboven nach en dach donde om het puntien aen het oudt huijs bij Carpentier cammer, die den $24^{\circ}$ ditto begonnen hadde; voor middach liedt ick naer haer missigidt oft tempel schieten, omdat het haeren Sondach was ende recht op den tijdt aff sermon doen; de coegel ginck door de cap van den tempel, soo de priester just met een splinter in 
Den $9 \mathrm{~d}^{0}$ Hans Vervack, adel ${ }^{\mathrm{b}}$, geschooten. Wirden oock den selve 3 grove schooten ghedaen door de slaepcamer van E. $\mathrm{H}^{r}$ Generael ende door de predickstoel, bij den selve op de groote saele opgerecht. Begonden hen oock de Javanen des snachs te begeven in de afgebranden toren van de: Engelse logie, staende een steenworp recht tegen over het fort, daerwt des nachts met musquetten de waterhaelders seer verhinderde; doch door verscheyden scheuten groff geschut, daerop gelost, syn geruymt en van daer hen achterwaerts naer $t$ bos begeven, ende aldaer begonnen een baterij op te werpen, $t$ welk van $t$ fort wel beschoten doch niet conde verhindert worden. Wttet fort sijn oock verscheyde scheuten ghedaen op Wattingh batterije, laghen achter 't oude huijs; doch wat ghebroocken oft stucken gheschooten wart, is des nachs weder op gemact.

De onse tot Bantam sijn, als gleseyt is, soo naeu van des Coninckx volck bewaert, datse noch wt, noch in de lodsij conde comen, tensij met weeten van de wachten en alsoo ghenochsaem in de handen van den Coninck stonden. Daer wert ook verscheyden mael bij den adel voorgeslagen, haer te vermoorden en om $t$ leven te brengen, dan soot geruchte ginck, wert door Gabangh telcken mael tegen gehouden. D' Engelse oock deden oock soo vele quaets, als immers conden; soeckende alle occasie en gelegentheijt om het fort te beschadigen; dan met de Conninck noch niet vereenicht synde en conde niets sonders verrichten. Hebben oock van den Coninck tot Banten eenich cruyt te coop ofte mogen macken versocht, dan is bij den Coninck niet geconsenteert.

Ady $11 \mathrm{~d}^{0}$ op des stadts tempel schietende, hebben den priester sijnen eenen arm door een gevloogen splinter afgeschooten, daer af in corte dage daer naer is ghestorven.

sijnnen arm gerackt wirdt, gelijok wij naderhandt rerstonden, ende corts daer van gestorven.

Den $12^{\text {en }}$ ditto stirff Joost de Hasse soldaet. Daer wirdt een soldaet denselven dach met een isser van $4 \mathrm{ir}$, op het secret sittende, door sijn boorst geschooten waer van corts daer naer oock gestorven is.

Den $13^{\text {en }}$ op een sondach $\mathrm{s}$ morgens, naer datt de op alle de 4 punten schudit geplandt was [B II: „soo 't vierde puntjen aent Huys Nassouw voltoyt was"] liedt ick metten sonnenopganck op ider pundt een nieuwe vendel oprechten ende van ider pladts het geschudt, dat de stadt beschieten con, rontsom daer op afschieten tot een tecken, dat nu de platssen deffencief g.noech voor een aen loop waeren". 
Adij $12 \mathrm{~d}^{\circ}$ sterf Joos de Hase, soldaet. Een van de Engelse schepen, 't ancker ghelicht hebbende, is tseyl gegaen, stellende zijnen cors t' seewart.

Ady $13 \mathrm{~d}^{\mathrm{e}}$ 's morgens ontrent 2 uren voor sonnen opganck hebben de Javanen hun verstout een fergadt ${ }^{1}$ van onder het fort naer de stadt te halen, twelck d'onse, gewaer worde, meynden sulcx te verhinderen, dan was bij de swarte soo vast gemaeckt, dat se, binnens haer muere staende, tselve sonder perijckel naer haer trocken, soo dat van de catte met een grof gheschut dwers door schooten, en alsoo tusschen beyde ghesoncken is. Met den dach werden op ider punt nieue vendeler op gesteecken en met eenen gelost alle de stucken, daermede de stadt ofte vijants wercken conden begaen en een van d'edellieden gematteert ${ }^{2}$ hebben. Dit, soo sij naderhant verclaert, hadde beijde de meeste ende minste meerder vreese onder hen gebracht dan noch oyt geschiet was. Van dese tijt af hebben de Javanen verscheyde brieven hijer ende daer om het fort bij nachte aengeslagen en aen stockgens opgerecht, daer van den $14 \mathrm{~d}^{0}$ twee van onse sijn gevonden, dan vermits in Maleijtse letteren ${ }^{3}$ geschreven waren en conde van niemant in 't fort ghelesen ofte verstaen woorde ${ }^{4}$; dan wart gemerckt ende gextimeert van den Cooninck ofte ten minste bij sijne kennisse opgesteecken waeren, daeromme goet gevonden wert in Chineesche tale, door dien geen nader gelegentheijt en hadde aen den Coninck te ombieden, dat soo iets begeerde, tselve en sijn meeninghe in Chinnessche taele te laten weeten, ofte andersints jmant van de sijne met een wit vandelken voor 't fort soude senden, men hem in alles antwoort soude geven; welcke Sinneeschen brief een stuck weechs buyten 't fort aen eenen stock mede met een wit vaendelken wart geplant, ende des naemiddachs door een Javaen afghehaelt en voor den Coninck int hof ghebracht wert. Tegen den avont is de schriver van de sabander met een wit vandelken voort 't foort gecomen, versockende met hen wt Conincx name te sprecken, mede

1 B II zegt: „de galleij”.

2 "Matar", Port., Sp. = dooden.

3 B I zegt: „int Malley's geschreven"; B II „in Javaens geschreven."

+ B I voegt in: dan alle[e]n de cockx vrouw verstont sommighe woorden, diesse selff las, daer uijt ordelden dat van den Conninck ofte ten minsten bij sijnne kennisse geschreven en opgerecht waeren. 
brengende eenen nieuwen brief int Maleyts voor den Coninck gheschreven. Alle het volck int gheweer geweest synde, is binnen 't fort ghehaelt, ' en heeft aldaer de mede ghebrachte, als de 2 andere becomen brieven gelesen en vertalt, van de dewelcke de somma was, dat den Coninck soo 't moghelijck was ende Hollanders daertoe verstaen wilde, sochte in vrede te leven ende alles weeder in de vooriche stant te stellen; daerop die van 't fort te antwoorde gaven, datse behoudens 't fort gerechticheijt even het selfde ende niet anders sochte, soo sulcx alles sonder bedroch en listicheijt soude connen gheschieden; daerop hij weder vertrock, seggende wyder daer van met den Coninck te willen spreecken en op morgen nader bescheyt brengen. Terstont is binnen 't fort een vttematen groote verhandelingen en blijschap aent volck bemerct: en oock de Javanen liepen met groote menichten op de mueren, begonden met praeuen te varen ende haer alome buijten te begeven; dan, alsoo het getal des te veele wirt, die in de afgebrande quartijer 't eene en het ander begonden op te graven en te socken, oock cijckers ende gapers bij menichte te voorschyn ende te nae bij het fort te comen, sijn ten laste gewaerschout te vertrecken, off anders daer inne gheschooten soude werden. En alsoo sulckx niet en mocht helpen en tot verscheyden reijs hem toegeropen wert, is ten lasten eene van Coninckx wegen weder inde stadt gecomen, presenteerde met 4 man daer dien nacht de wacht te houden, om de Javanen van de heyningh te keeren; doch wert afgeslagen en onnodich geacht, ende aengeseyt alle het volck soude doen vertrecken, eer eenich ongeval daerover mochte ontstaen, $t$ welck ten laste gheschiede.

Den $15 \mathrm{~d}^{\circ}$ is de schriver voornd andermael met tselve teecken en eénen brief binnen 't fort gecomen; was meest van inhout als de vorige, ludende dat den Conninck, volgende het oude contrackt met hem gemackt, niet anders sochte dan in vrede te leven. Mede dat die van 't fort daertoe oock ghesint sinde, jmant vande haere int hoff souden senden omme met hem te sprecken; presenteerde wederomme eenige van de syne in hostatie te laten, waer toe gecommiteert wert Evert Harmansz,

1 BI: „Iok liet al de soldaten in de wappen gaen, en liet hem int fort sonder geweer commen, bracht ons een anderen brieff van den Conninok die hij voor ons altsamen int oppenbahaer las". 
Josepij te Natlaer, ondercooplieden, ${ }^{1}$ ende Hendrick de Haen, doctoor, om hem te hooren en syne rechte intentie te verstaen en voor van vrede ende stilstant van wapenen te handelen; die oock op den $16 \mathrm{~d}^{\circ} 2$ voor hem gecompareert syn, dan soo haest jets voorwenden, en wilde den Coninck van geene dinghen handelen, voor en aller hem toegeseyt ende belooft warde, dat de catte ende punt aen 't eijnde van 't out huijs ${ }^{3}$ souden afgebrocken ende geraseert worden, daerop in haeste antwoorde begeerde; daerop bij die van 't fort geresolveert wert, hem ten antwoorde te geven sulckx te doen geensints gesint en waren, ten aensien de macht van de Engelse tegenwoordich ende voor de hant sinde; dan soo de oude alliantie begeerde te continueren, garenen met hem handelen ende vant voorder fortifieceeren wel wilde ophouden tot de comste van den $\mathrm{H}^{\mathrm{r}}$ Geńerael. Ende om het selve rapport te doen, wert syne versoecken gecommiteert den predicant A. J. Hulsebos, ${ }^{4}$ Evert Harmansz, ondercoopman, ende den doctoor voornt, die oock op $17 \mathrm{~d}^{\circ}$ ten hove voor den Conninck en ganschen adel van Jacatra ende veel van Bantem gecompareert syn, blivende in haer plaets voor ostagiers 2 orangkaijs " ende den schrijver, den soon van den Sabander voors. Hunne commissie bij den Coninck verclaert hebbende, wilde de Coninck, noch synen adel, int eerste niet vorders hooren voor als vooren den punt beloofden af te brecken; daerop hij hem gerepliceert worde, de Hollanders daertoe niet soude resolveren; wat derhalven den Coninck beliefde dat gedaen soude worden, te weten de sacke te stacken, de roode vlagge weder uwt te steecken, oft wat. Daerop den Coninck antwoorde: orang ollanda pitsiara cras, condati, dialo mau backelaij akou mau backelaij juga, mau moefacat mau moefacat lagi ${ }^{6}$. Doch naer lange debat aldaer gehouden, de Coninck wel gevoelde, wat d'intentie der Hollanders was, begonden te renuiccieren en te clagen veele schade in de oorelooge geleeden te hebben, soo in volck, batterijen ende anderen

1 Joseph Jansz de Natlaer. B II noemt evenals B I Evert Harmensz, opperkoopman, hetgeen door Camphuis is overgenomen.

2 Van der Chijs p. 81 en 82 stelt deze en de volgende zending één dag te vroeg.

3 Dat zijn dus de beide landpunten.

4 Er staat A. J. en niet Adriaen Jacobsen; de schrijver achtte het niet noodig zijn eigen voornamen voluit te schrijven.

5 Een van deze was de zoon van Kjai Aria. Verg. De Jonge IV p. 140.

6 orang bĕlanda bitjara kĕras, kĕndati, djikalau maoe bĕrkalahi, akoe maoe běrkalahi djoega, maoe moeafakat, maoe moeafakat lagi. 
oncosten, bij hem ter diffentie gedaen. Item oock dat de Họllanders een groote somma gelts, ${ }^{1}$ doer diense tegens verbont en belofte met de Engelsen in sijn juredictie in orelooge getreeden waren, oock dat d'onse int timmeren van catte buijten het contract ende de genomineerde luijden hun hadden begeven, hebben verbeurt; waerop de voorn. gecommiteerde difentie met veele redenen int eerste deden, doch alsoot 't selve menichmael soo van den Coninc en adel herhaelt wert, lieten hen volligens haere commissie in 't eijnde verluijden, datse niet gesint en waren, haer met Coninckx schade ofte onrede te behelpen, maer lievers soot den Coninck om een goet stuck gelts te doen waere, haer daeraen niet en wilde laten cennen, soo anders de sacke en vrede sonder arch en bedroch daer mede conde getrosten, ende de Hollanders haren eysch becomen worden; waer op den Coninck hem hielt als niets daernaer te willen hooren en tegen den omsittenden adel wat int heymelijck gesproocken hebbende, seyde men soude het cort macken, en t'en oft ander bij de hant nemen. Ende gesanten voorn ${ }^{d}$, vragende wat dan souden doen, en wat rapporten aen den raedt souden brengen, daerop antwoorde: tida tau, condaty ${ }^{2}$. Ende selve van den Coninck ende raet oorelof nemende, is den Conninck opgestaen ende sonder sprecken vertrocken. De vooren[genoemde] meede gereet staende om naer 't foort wederom te keeren, is bij den Coninck geroupen Quiaij Area en naer een weynich malcanderen soetelick ghesprocken te hebben, is den Tommagon bij den doctoor gecomen, hem ingevende, men mochte de Coninck niet soo rondelicken tegen sprecken, maer met een stuck gelts socken te inclineren, hij en twijffele niet oft soude noch wel ten besten comen, te meer om dat de gesanten van Bantam derwaerts gecomen waeren omme de Coninck tot vreede met het fort te vermanen, ende hij oock daer inne veel soude doen, alsoo den ooreloch niet ander mede bracht dan beyde reuijne en verderff. $t$ Selve heeft Quiaij Area oock onderweegen naet 't fort gaende tot 2 a 3 reijsen de gecommitteerden verhaelt en ingegeven, daer op geantwoort wert, men achte de Hollanders daertoe nu seer qualicken soude wille verstaen, dan dat men tselve voorhouden en aendienen soude.

Adj 18 d $^{0}$ Quiaij Area met den sabander wederom voor 't

1 B I noemt hier de som van 4000 realen van achten.

'B I: tida mauw, condaty. 
fort comende hebben haere ostagiers binnen gelaten, en sijn de voorgen $^{e}$ gecommitteerden weder naer 't hoff gegaen, alsoo den Coninck ende den adel vergadert sijnde, hem spoedelick hadden ontbooden. Op de merct comende, vernamen datter Engelssen in 't hoff bij den Coninck waren, dies den voorn. Quiaij Area hun riet wederom te keeren en in sijn baterije, bij ons genaemt Wattings baterije, hem te onthouden, ${ }^{\mathrm{I}}$ tot dat hij selve wederom wt het hoff bij hen soude comen. D'Engelzen te weten $\mathrm{M}^{\mathrm{r}}$ Adam Denten, ${ }^{2}$ een constapel mayor en noch 3 anderen met hem wttet hoff gaende, hebben vernomen, datter Hollanders over de reviere aen Wattings bolwerk gevaren syn, die daerop met eenen grammen en bijnae tijgers gelaet bij hem syn gecomen en hun beset hebbende, riepen met grammen ende ongestuijmigen gemoede hun geweer treckende: sa messieurs, legt $\mathrm{u}$ geweer af, laet $\mathrm{u}$ binden en d'oogen verblinden, en gaet met ons naer den Coninck en daer 't ons gelieft; daerop geantwoort wert, daer niet en waren gecomen om met hem, maer met den Coninck te handelen. Vrachden oock, wt wiens name of last sulcx seyden, antwoorde "wt des Conincx en haren Ginnerael»; die geseyt werde niet te kennen, oock niet gesint waren mede te gaen voor en aleer sij hadden hooren sprecken, die hem daer hadde gebracht. D'Engelsen fulmineerden seer op den E. $\mathrm{H}^{\mathrm{r}}$ Gen ${ }^{\mathrm{l}} \mathrm{J}$ : P. Coen, segende hij oorsacke van alle dese swarichheden te syn, en nu haest soude 't onderleggen, mede souden hem behenc en soo tracteeren, dat men sien soude dattet haer leet ware, de hare in de Mollucsse als besten ghehandelt wirde; oock ons nomde honden, die met den hondt, den Coninck, sochten te tracteeren, en dattet beter ware te tracteeren met haer ende met haer Kingh; daerop geantwoort wert, gene commissie te hebben. De poincten nu, die voorgecomen waere den Coninck te proponeren, waren onder den predicant be-

1 De gecommitteerden waren dus Watting's huis voorbijgegaan, voor zij op de markt kwamen, aan de overzijde der rivier. Van den Broecke zegt, p. 91, dat de ontmoeting met de Engelschen plaats had in "des Graven Quartier", alzoo in de kampoeng van Kjai Aria. Hier wordt dus bevestigd, dat deze kampoeng op den rechter oever der Tjiliwoeng lag. B I zegt abusievelijk: „doch eer ons- volck int grafkens quartier ontrent Wattineks huys quammen"; bedoeld wordt "terugkwamen".

"Adam Denton, een „old acquaintance" van Hendrick Jansz op Patani, die de onderhandeling leidde bij het overgeven van de Zwarte Leeuw. Purchas V, p. 11. 
rustende, en d'Engelsen een weijnich vertrocken ende van mennige synde aen d'een sijde van de baterije wt te comen en haer den wech tusschen 't fort aff te snijden, wert goet gevonden de selve artickel punten te scheuren en van cante te helpen, opdat, off het een doorsteecken werck waere met den Coninck ende haer, ghelijck het sich toonde, tselve geschrift in handen van d'Engelsen niet soude geracken, 't welck oock heijmelicken gedaen wert. Hier is op den Quiaij Area wt het hof gecomen, hem gelatende van de Engelsen niets te weten, en vrachde hun, wat begeerde. Seijden: de Hollanders in hunne handen wilden hebben, ofte soudense soecken met gewelt te becomen. Aria antwoorde, geene moeyte souden binnen syn platse macken, hadse vrij daer gebracht ende begerendense oock vrij wederom aent fort te brengen. Viele veele woorden, soodat d'Engelsen haer geweer en 't graeffken sijne crisse trocken ende de Javanen over eynden geracten. Ten lasten wert de gecommitteerden van Area belast, hen acteruwt te begeven, en naer 't fort te vertrecken; sulcx tot 3 a 4 mael herhaelde. Seyde op een ander tijt nader met malcanderen te sullen sprecken. Alsoo syn de voorgenomde sonder jets te verrechten, weder binnen 't fort gecomen.

Naer de middach is Quiaij Area wederom voor 't fort gecomen, versockende jemant beneffens hem Wattings baterije mochte gesonden werden, mits in ostagie de voorn. parsoonen; seggende aldaer was afgecomen de Pangeran Tommagon, des Coninckx broeder, hebbende volle last ende commissie te handelen, sooals tusschen beyden soude gecontracteert worden. De voorn. gesanten aldaer gecompareert synde als vooren, heeft de Pang. Tommagon in 't large gepreponeert, hoe de Coninck door d' aengedane oorelooge groote schade hadde geleden, groote onkoste hadde gedaen, oock hoe de Hollanders hare beloften van met d'Engelsen in sijn lant geen hostiliteyt te sullen ghebruijcken, veere waren te buyten gegaen, en dieshalven volgens voorgande en oude verbintenisse hadden verbeurt 4000 realen, en dat derhalve, in 't eene met het ander gereckent, den Coninck alsoo wel sach de Hollanders tot het afbrecken van de punten niet en soude verstaen, nochtans om met vrede te handelen ende te negocieren als voren alles billick toe quam, en dieshalven oock eyschte de somma van 8000 realen van $8^{\text {en }}$. Daerop als voore in't large geantwoort is, noch sonder wichtighe oorsacke de ooreloge tegen d'Engelsen niet waere aengevangen, noch oock sonder weder 
schade niet gecontinueert en waere; ten laesten, immers naer langen debatten over en weder en naer 't proponeren van de poincten bij den raet gearresteert, syn de voorn. wederom vertrocken, seggende 't selve aen de raet van 't [fort] te sullen aendienen '; en hun antwoorde daerop, wijders mochten vorderen als hun geliefde; 't welck geschiede.

En alsoo de fortresse noch gans onversien waeren en niet langhe veele gewelts soude connen verdragen, oock op hoope van de glorieuse hochmoet van de Engelsen wat te contuleeren ${ }^{2}$, het comptoir tot Bantam te verseckeren ende de vrienden aldaer wat te ontlasten, oock mede omme te preserveren de mennichte van costelijcke packen, die dees lange voor borstweringe waren gebruckt geweest, oock wetende seer weynich cruijts hadden en het geduerich schieten op hunne ${ }^{3}$ en baterien niet soude langhe continueren, en alsoo goede gelegentheyt soude becomen om tot Bantam ende van daer wederom herwaerts ten believe te advijseren, daerdoor onse comende scheepen soude connen gewaerschout worden omme niet onweetende in handen van d'Engelsen te geracken, is voor goet inghesien de Coninck te vereeren de somma van R. 6000 , te weeten vijff dusent in contanten, de reste in cleeden ${ }^{4}$, 'twelck oock door de voornoemde gecommitt. [uit] den rade, weder op 's Coninckx versock aldaer gecompareert synde, hem belooft en toegeseyt is; dan om van alles verseckert te syn, begeerden de voornoemden selve eerst met den Coninck oock te mogen spreken om hem daervan mede in eygen persoon te hooren, oock syn hanteeckeninge daervan te versoecken, 't welck geavijeert wert, segende hem op morgen in't hoff te sullen ontbieden, hen toestaende hunne bedongene poincten schriftelick mede te brengen omme van [den] Conninck ghetekent te mogen werden.

I B I zegt hiorna: 's avons beriep ick den Raet, dewijll het een gewichtighe sacke was, omme te resolveren, wat men voor beste hierop antwoorden soude; in s smma is, enz.

Controleeren; zie p. ${ }^{6} \%$ bij het verhoor van Hulsebos.

3 Uitgolaten: huizen?

4 B I zegt: „dat men den Conninck voor de geaijste 8000 realen en den Pengeram Dommagom, 6000 realen, soo voor sijn schade ende verbeurte van de 4000 Realen, soude toelagen".

Van den Broeck voert nu de redenen aan, welke hier voorafgaan, en welke tot het sluiten van het verdrag hebben geleid. Hij noemt ook daarbij:

"mede dat boven twee maenden waater int fort niet conden bargen bij soo verde sij ons t waater hallen beletten, dat licht om [te] doen was". 
Den $20 \mathrm{~d}^{\circ}$ 's morgens door Quiaij Area ghehaelt synde, syn de voorgenoemde, den predicant A. J. Hulsebos, den ondercoopman Evert Hermansz ende den doctoor de Haen met Pedroo, den tolck, voor den Coninck gecomen, die beneffens hem hadde beyde synne broeders, den priester en Tommogon met eenige anderen adel meer, die aldaer de pointen met syn broeder geaccordeert verscheyden male mondelicke voor ghehouden, en andersints wt het gheschrifte van punt tot punt verduijscht ${ }^{1}$ hebben, en daerop syn hanteekeninge hebben versocht, 't welk hij, naer verscheyden reeden eerst met de selve gehadt hebbende, ten laesten consenteerde en naer quam. De geacordeerde ponckten waren deese: dat het contrackt tusschen den Cooninck ende d' El. Generaelen $\mathrm{P}^{\mathrm{r}}$ Bot ende Reynst gemackt soude effect als voor desen geschiet is; 2 . het fort soude blijven staen in effect als het was tot de comste van d'Ed. $\mathrm{H}^{r}$ Generael ofte de vloote wt de Mollucques; 3 . de Coninck soude niet mogen toestaen, dat d'Engelsen eenige logie, soo naebij als voor desen het fort geweest was, mochten bouwen om alle ongeval te vermijden; 4. en soude geene Javansche ofte Chineesche woonigen nader dan op 20 vadem aen de pagger van het foort gemackt worden, des soude den Coninck getelt worden de somma van 6000 R. ${ }^{2}$ Actum 19 Jannev. a ${ }^{0} .1619^{3}$. Geteeckent aen beyde syden en daeraff 2 alleensluijdende. Dit aldus ghedaen sijnde, sijn de gecommiteerde weder naert foort vertrocken, vergeseltschapt met sommighe Javaensen adel, en hebben het ondergeteeckende contrackt in't aensien van de geheele borgerie Pieter van den Broecq, commandeur, over gelevert, ende wirt aen beyde syde de witte vlagge opgesteecken ende gaende blijtschap betoont. Het gelt ende de cleeden wirden oock den selfden dach in handen van den sabander daer henen getelt ende aen den Conninck gebracht. Terstont werdt van alle canten groote verversinge aen 't fort gebracht en oock veele presenten ende schenckagie gedaen, soo van Javanen als die van binnen.

Op dato syn doen d'Engelsen schepen van de rede vertrocken,

1 verduijscht, wel "vertaald".

2 Zie Van der Chijs, Bijlage V p. 210 en 211.

${ }^{3}$ B I voegt in: "Den selven dach quam den Renoster wederom onder het fort waijden, die ick voor den orloch om geen waater gebreck te hebben, hadde laaten loopen. Dit beest was den swert, die op hem gepast hadde, soo gehoorsaem dat ider een daer van verwondert was."

"Aldus verthoont hem de Rennoster". De afbeelding van den rhinoceros. 
stellende haren coers naer Bantam; ondertusschen hebben wij tijdinge becomen, dat het schip Harelem ende 't jacht 't Hart met een veroverde Spansche prijs den 13 en 16 wt 't patria voor Bantam in salvo waeren gearijveert, dan alsoo de vrienden van Bantam geadvijseert waeren, hoe de sacke aldaer gelegen was, syn haestelijcken vertrocken, stellende haeren coers wederomme stratewarts inne, op hoope door d'eene off d'andere gelegentheyt bijde vloote te geracken, ofte eyntlick na Amboijna te loopen, en dit te meer omdat haer d'apparentie omme ontrent het fort te comen door d'Engelsen, die vast alle vlijt deden hun te attrapeeren, afgesneden wert. Den selfden sterf Adolf Alardij, soldaet.

Den $22 \mathrm{~d}^{\circ}$ sant den Coninck van Jacatra binnen 't fort den sabandar met eenige andere ooreng kays meer, begeerende dat $S^{r}$ van den Brouck, om alle vriendschap te continueren, om de lijeden ende 't gemeen volck te voldoen, ende om sijn afscheijt aen den adel van Bantem te nemen, die nu gereet waeren om wederom te vertrecken, bij hem ter eere en wat meijen wilde comen, hetwelcke hoe wel 'tsommige ${ }^{1}$ gaeren hadden verhindert, nochtans bij de meeste geadvoijeert is, alsoo dat den selve vergeseltschapt met eenighe goede schenckage om aen den Conninck, jonge Coninck en Conninginne te doen, hem naer de stadt en 't hoff begeven heeft, vergeseltschapt met den doctoor $\mathrm{H}^{\mathrm{r}}$ de Haen, Dirck Jemmingh, Jan de Meyn, adelborst, Jelis Carel, soldaet, ende 2 Japponse, de welcke alles soo haest in 't fort ${ }^{2}$ voor den adel verscheyden sijn, ${ }^{3}$ soo firieuselicken overvallen geworden, geplundert en gevangen genomen en in blocken gestelt syn, contrarie het nieuwe verbont, over 2 dagen gemackt en bij 'sConinckx hant in onser presentie onderteeckent. En den bottelijer ${ }^{4}$, op de mart synde, wert mede aengerant ende bij de andere gevanckelijcken gestelt. Des avonts isser eenen jonge van $S^{r}$ Houbracke met een wit vandelken voort ' $t$ fort gecomen van $\mathrm{P}^{\mathrm{r}}$ van den Broucq gesonden een brief, daarinne gementioneert wert, hoe ellendich de sacke met hen ghegaen ware en nu in den heijdenen handen gevangen en gebonden

\footnotetext{
1 Namelijk Ds Hulsebos zelf.

2 Lees: in 't hoff.

3 Lees: verscheynen.

- Philips Adriaensz van der Werff, later schepen van Batavia. De Jonge, IV p. 223 vlg.
} 
lage. Die van binnen 't fort, siende hun soo schandelick bedroogen, hebben terstont weederomme de poort geslooten, 't gemeene volck weder moet ende coerasie aengesprocken en de packen, die men hadde beginnen wt de borstweringe te salveren, wederomme daerinne gebracht; voorts alle arbeyt aenwendende omme op nieus te fortificeeren, vreesende voor meerder quaet, te meer om den Coninck aent fort hadde laten ontbijeden, off sij nu noch wilden vechten ofte hen tot een nieue accort met hem te begeven, daerop niet varders geantwoort en wert, dat ons forse en geen recht gedaen en wart. ${ }^{1}$

1 B I verhaalt deze gebeurtenis als volgt:

„Op welck instantje[lijek] versoeck iek den Raet vant $t$ fort ofte logi liedt vergaderen, ende geproponnert ofte sulckx ratsaem ende orberlijck soude wesen, presenterden ingevalle den Raet considereerde den dienst van de Compe ende landt daer aen gelegen was, mijnne dinst, ende naer sommighe swaricheden gealligert ende voorgewent hebbende, vraechden sy stemmen, ider int besonders om, gaven altsamen eenstemmich [behalve de predikant dan toch !] ten antwort geraden te wesen, dat ick met den docktor Hendrick de Haen, Dirick Lamberssen [Jemming], Jan Domijn adelborst, Gilles Carel soldaet en 2 Japponders darwaerts soude gaen met een clijn present voor den Coninck en sijnnen soon en conniginne. Ick sulckx verstande wilde mijn woordt, omdat sij ordelden orbor voor de Comp ${ }^{\circ}$ was, niet wederroppen, weynnich denckend datter niemant sijnne dienst soude presenteren gelijck altijd eertrachtende soldaten doen.

Soodat ick int jonckxte ontrent de clocke 10 naet hooff in de name Godes vertrocken ben; daer commende deden ons sitten maer soo hast geseeten was is ons dese cannali met alle man seer furieuselijek overvallen en geplundert, voor handen en voeten seer strengelijek gebonden; daer naer tot voor den conninck geslept, alwaer de Engelssen present waeren, die raetgevers en inventeurs van dit spul waeren, soo den Conninck ons selff liedt seggen. Infien wirden datelijek met alle wan in houtte blockx aen handen en voeten daer naer in de issers geslooten, ende met een starcke wacht bewardt. Den bootelier van de logi Philips van der Werff, die voor ons uijt de logi gegaen was om wat vervarssing te coopen, hiervan niet wetende, hebben hem mede met veraderij gecregen ende soo gebonden bij ons gevangen ge. brocht, soo dat met ons achten starek gebonden waeren.

Den Coninck ende Engelssen deden mij een briefken naert fort schrijven, dat die vant fort hun datelijek souden overgeven ofte datsse tsammen 't fort wilden bestormen ende al doot slaen datter binnen was, welck brifken door den coopman Cornelis Houbracken, die te vooren van Bantam met den adel hier gecommen was, int fort gesonden wirdt.

Soo hast die vant fort onsen veraet ende ongeluck verstaen hebben, deden datelijek de poorten sluijten, 't gemenne volok moet ende coragi gevende, voorts nach en dach wederom beginnen te fortificeren; s'avons quam den coopman Cornelis Houbracken die te vooren met den adel van Bantam gecommen was als vooren ende ons verhalde, dat hem den conninck van Bantam 
Den $23 \mathrm{~d}^{\circ}$ wart aengevangen het nieue huijs Mauritius met aerden te vullen, 12 à 13 voeten dick, buijten de 3 voet muers om alsoo tegen 't geschutschoot vrij te syn en de plaetse veylich te mogen houden; oock voor de borstwering op de punten versterckt, soo veele als inder haest gheschieden conde. Den selven sterf Pieter Jacobsen van Delff, soldaet.

Adij $24 \mathrm{~d}^{\circ}$ wert door Pang. Padijaxae, 1 's Conincx schoonvader, tot teecken van vrienschap met de Hollanders, geeyscht 2 stucken geschut met haer toebehooren, cruijt en loot, tot vereringe, ende 10000 realen van achten tot ransoen ende verlossinge van de ghevangenen persoonen, ende de $25^{\text {e }}$ d $^{\circ} 500$ realen te leene met belooften, die ter ghelegener tijt wederom uwt te ceeren; presenteer wijders soo een sacke voor den Coninck synen schoonsoon hadde, ons in alles faveurabel en hulpich te sijn; daerop ten antwoorde gegeven wart, dat om seckere reden tot het uwt keeren van geschut niet conde verstaen, dat oock 500 rialen voorde Comp $^{\mathrm{a}}$ een cleyne sacke was, soo alle dingen ten beste nae behooren succedeerden; dat oock de vrienschap met den Coninck te willen houden genochsaem met het nieue contract betoont hadden, ende sulcx noch meer souden betoont hebben, soo nu die niet met valsheyt hadde beloont, en derhalven, soo den Coninck ghesint waere de gecontracteerde vrienschap te continueren, haer de gevangen vrienden wederom binnen $t$ fort soude senden. Dan en is niet af geworden, maer den Coninck sant andermael met een wit vaendelken aent 't fort een letterken door $\mathrm{P}^{\mathrm{r}}$ van den Brouck geschreven, daer onder stont, wt name van den Coninck begeerde, dat die van 't fort, soo de vreede ende haere gevangenen wederom begeerde, soude de catte ende de punt aen 't oostsyde vant huijs Nassouw affbreecken en slechten, ofte dat sij souden vertrecken; presenteere haer daer toe te bestellen een Engels schip, oft soo geen van beyden en wilde aengaen, hij met syn ende

expresselijck gesonden hadde, omme ons met den Conninck van Jaccatra sien te vereenigen. Ink vont goedt, dat hij datelijek wederom naar Bantam soude vertrecken, en assisentie aen den Conninck tegens dese veraders d'Engelssen ende Javanen versoecken, dat niet twijffelde de E. Heer Gen al met sijn comst sulckx ongerecompensert soude laaten, al waer mede om met sulcken middelen dese ongelovige honden in thoom te houden ende den tijdt son te verlengen, ter tijdt ons Godt Almachtich ander middelen ofte secours gelieve thoe te senden."

1. Pangeran Padjadjaran. Coen schrijft: Paddigiaran (De Jonge IV p. 167). 
d'Engelse macht hen daertoe soude dwingen. Daerop den $26 \mathrm{~d}^{01}$ gheantwoort wert, dat seer verwondert waeren, den Coninck van nieue vrientschap en vrede macken [sprack]; seijde, dat hem selven alreede de vrede ende viant hadden betoont, dat tot het afbrecken van genomde punten ghelijck als vooren geensins en souden verstaen; aengaende het vertrecken, daer

1 De lezing van $\mathrm{BI}$ is:

„Den $26 \mathrm{~d}^{\circ}$ moost ick door last van den Conninek en de Engelssen wederom een briefken nart tfort senden, dat sij de eatt ende de pundt vant oudt huijs souden aff brecken, in gevalle sij ons weer liber en vrij begerden; soo niet mochten vertrecken. Hij wilde haer een schip van d'Engelssen laaten prepareren, ofte dat hij haer anders met hulpe endc assistentie vande Engelssen daer thoe dwingen soude.

Die van 't fort gaven te antwoordt, dattse in genderlaij mannier gesindt warren imant in sulcker conjonture te geval de catt off pundt aff te brecken; belangende het vertreck van Jaccatra mackten daer weynich off geen swaricheijt in, om datter weijnich ofte niet aen Jaccatra gelegen was, gelijokt gebleeken is, doen de E. Heer Genal Jan Pieterssen Coen hem dickwils voor sijn vertreck presenterde te willen vertrecken door dien de middelen daer thoe voor de hant waeren, hetwelek hem doen niet vergundt en wirdt; darom nu oock niet van sin waeren te vertrecken voor en aleer de E. Heer Gen ${ }^{\mathbf{a l}}$ selve in persoon wederom gecommen soude zijn, maer het uijterste te verwachten dat hun Godt almacht soo beliefte verlenen.

Gedurende dese handelingh heeft den Engelssen Admirael Thomes Dael met veel groote beloften en geschencken een verbont ende contract met den Coninck van Jaccatra gemackt, omme tsamen de Nederlansse fortresse met hunne baterijen rontsom te besetten, beschieten ende daermede met gewelt te bestormen en vermeesteren, ingevalle die vant fort tot geen accordt wilden verstaen. Daerop datelijek partij groff geschut met tghene daer thoe noodich aen landt gebracht, en in hun opgeworppen baterijen geplandt hebben.

De conditien tusschen de Engelssen en den Conninck van Jaccatra warren, dat den Conninck de gerecht helft vant goedt, volck ende geschudt ofte ammonietie van orloghe, d'ander helf de Engelssen, die dan gehouden souden moeten wessen de loogie ofte fort te rasseren, dat voor een groote eer ende privelessie hilden.

Eer de Engelssen met den Conninck dit contract aengingen, vereerden sij den Conninck 2000 realen van $8^{\text {en }}$ in contant met noch eenighe ammonitie van orloghe.

Den $27^{\circ}: 28: 29^{\circ}$. ditto veel praatgens over en weder gesonden. Die vant fort booden 2000 realen van $8^{\text {en }}$ voor mijn ranson midts conditie, dat den Conninck mij eerst int fort soude senden, daerin niet wilde verstaen, maer sondt mij gebonden op de pundt van de stadt recht tegenover de catt, om in sijnnen naem $t$ fort op te aijssen met de Engelssen, dan soo sijet datelijck niet overgeven wilden, wilden sij tsamen datelijek $t$ fort beschieten, ende daer naer bestormen, ende niemant bij den lijve laaten blijven. Ick, hun radende stantvastich te blijven, gaven ten antwoord hun beraet tot sanderdach te nemmen". 
in en hadden wij geen swaerricheijt door dien aen Jacatra soo gheheel veel niet geleegen ware; dan alsoo sulcx door den E. $\mathrm{H}^{r}$ Generael Coen den Coninck tot verscheyden mael aengepresenteert was, doende middelen daertoe voor de hant waren, en hem die niet vergunt is, nu oock niet van sints waren haer van daer te begeven, maer noch een tijt te onthouden, omme niet van den 'eenen vijant totten anderen te geracken. D'Engelse macht, daer den Coninck haer mede dreijchde te dwingen, verclaerden geren selver te sien de uwtcomste daervan te verwachten, doch presenteerde stilstant van waepenen volgens de nieue verbintenisse tusschen hun luijden gemackt, daertegens sij gevoelde den Coninck gerechtelijcken niet en conde doen.

Gedurende desen handel hadde de Engelsen Generael Tomas Dael alreede voor veele en groote schenckagie een verbont met den Coninck gemackt om te samen de Nederlanse forteresse met hunne baterijen te besetten, te beschieten ende daernaer te bestormen, ingevalle sij niet tot hastich accoort en wilde verstaen; daerop sij met alle hun ghewelt en geschut daertoe noodich haer aen lant souden vervoegen en 't fort verovert synde, soude den Coninck genieten de helft van 't goet, gheschut ende het volck, en d'ander helft d' Engelsen, die oock souden hebben de prevelege en eere vant 't fort te mogen ruijneren.

Den $27 \mathrm{~d}^{\circ}$ wert wederom door Pangeran Padjarang versocht, dat men 't fort metten eersten soude abbandonneren ende hun tot vertrecken stellen, presenteerde des Conincx hanteeckeninghe, dat sonder eenighe naedeel ofte verhinderinge soude vergunnen. Eysten oock voor't ransoen van de gevangenen 5000 Rialen en dat sonder gheschut, welck gelt hij seyde den Coninck sijnen soone soude verstrecken tot reperatie van de schade in orelooghe geleden en tot contentement van de geene, die de hare hadde verlooren; daerop als vooren geantwoort is, sulckx niet van sin te syn, noch niet te connen verstaen den Coninck jets toe quame, noch voor geleden schade doordien alreede 6000 rijalen ghetelt hadde, noch voor de lossinghe van de gevangenen, doordien die tegen die beloften en trouwe hadden gehnuden. Aangaende het vertrecken wouden dat wel beloven en sulcx den Coninck met hantteeckeninge verseckeren, mits sulcks soude gheschieden ter comste van den Generael ofte de schepen van binnen, ${ }^{1}$ en niet eerder; maer den Coninck, wel gevoelende

1 Van binnen, d. i. binnen Straat Soenda; hier van Ambon.

Dl. 73 . 
wat sulcx in hadt, en heeft naderhant van geen vertrecken merder gewach gemackt.

Den $28 \mathrm{~d}^{\circ}$ verstonden, hoe Jacques Le Fevere, oppercoopman, den 10 stante $^{1}$ van de vloote en bij commissie van den Ed. $\mathrm{H}^{r}$ Generael was vertrocken met oordere om de aanstaende toecommende scheepen van't patria, Priaman, Andrigierij, Jambij, van de custe ende elders waer te nemen en van alles te verwittigen omme voor d'Engelsen [op] haer hoede te syn, ende dat het schip Harelem ende 't jacht 't Hert, met de prijs, op 18 ende 20 in de straet waeren gerescontreert en gevonden wel versien met goet volck, crijchsammonitie ende proviande, met meenige, soo veere d'Engelsen scheepen innewaert aen gingen, ofte haer op de reede tot het onset vant fort souden vervoegen; hadde oock de vrienden tot Bantam belast ende vermaent, geen gelt en souden sparen, omme die vant 't fort ende hem van alles spoedelickeen te adviseeren, en met schenckagien en andersins den Coninck tot Jacatra en Bantam tot vrede te brengen, mits oock voor veraderie wel voorsichtich te syn; en soo sulcx niet en conden te wegen brengen, 't selve met de Engelsen souden besocken, ${ }^{2}$ en soot gebeurde daer toe aen geen van beijden sijden conden gheracken en 't fort niet machtich waer te houden, het dan noch eerder geraden waere, 't selve te geven in handen van d'Engelsen dan van de Javanen voorn. Dit alsoo synde, hadden d'Engelsen ondertusschen aen den Coninck vereert 2000. rijalen, omme het geschut te moghen naer geliefte aen lant te brengen, 't welck haer vergunt wart. Den Coninck hiel noch al aen, versockende 't affbrecken van voors. punt ende het geeijstte ransoen voor de gevangene persoonen, seggende soo daerinne geconsenteert wert, Lacmoeij ${ }^{3}$ datelijck nae Bantam soude vertrecken om den Coninck alles aen te dienen, en soude dan een nieu contrackt in presentie van de edelen desselfden Conincx gemackt, ende bij hem wt 's Conincx name gheteeckent worden. Insgelijck versocht Pieter van Brouck alle dagen seer instantelijck, dat voor syn verlossinge doch iets mochte gepresenteert worden, daerbij voegende, so daer immers niet toe conde verstaen worden, de Javanen geresolveert was, 't fort een

1 d. i. 10 Januari.

S Besoeken, verzoeken, beproeven.

s Lackmoei, geschoren Chinees, Sabandar van Jacatra. 
nieuwe oorelooge aen te doen, en dat doch wilden in 't eersten eenen schoot 18 à 20 te verdragen ${ }^{1}$ om van alle occasie bevrijt te sijn.

Den $29 \mathrm{~d}^{\circ}$ den Coninck voor de verlossinghe van de gevangen persoonen presenteerde 2000 rijalen van $8^{\text {en }}$, eene [1000] contant en een in cleeden te betaelen, met conditie de gevangenen eerst en al vooren in 't fort soude gelevert worden, ende den Coninck een hantteecken soude geven van vreede en alle vrientschap te continueeren tot de comste van de $\mathrm{H}^{\mathrm{r}}$ Generael, ende dat alsdan alle sacke ten rechten souden afgedaen worden. Dan den Coninck over dit geringe bieden t' onvrede synde, heeft terstont het fort, volck en goet op ende in sijn handen geeijst, oft soo de persoonen hun niet in syn handen vertrouden, wilde haer syn praue verleenen om naer Bantam te vertrecken, en soo niet, het fort soude commen bestorremen, en 't selfde inghenomen hebbende, niemant bij 't leven te behouden. En dit geschiede tot 2 à 3 malen toe door Pieter van den Brouck ende den doctoor de Haen, die al gebonden aen de punt van de stadt gebracht en alsoo over te roepen bevolen wert, tot welck voornemen de Engelsen de Javanen gheduerich aenhisten, hen assistentie belovende ${ }^{2}$. Hadden oock al reede recht tegen 't fort over, daer te voren haer loge gewest hadde een groote baterie opghericht ende met 8 stucken geplant, ende noch 8 stucken gebracht in de baterije van Paep Jans quartijer op de hoeck van de riviere, en 4 op Wattings baterie achter 't oude huijs; 't welck, hoe wel bij die vant fort gemerct synde en oock geconsidreert haer weynich cruijts, groote swackheijt van hare wercken ende veel ingevallen volck, hadde nochtans haer in stilstant van waepenen te houden, soo lange anders te doen op 't vtterste genotsackt waren. Op den selve sterf Jan de Cock, soldaet.

Dachs voor desen hadden d'Engelsen verscheyden int Engels geschreven [brieven] met pijlen aent 't fort geschooten, daervan den $29 \mathrm{~d}^{\text {o }} 5$ binnen gehaelt ende genomen werden, daerin sij het fort opeijsten; presenteere seckere conditie ende voorwaerde, soo daertoe wilde verstaen; anders, protesteren onschuldich te

1 Alvorens terug te schieten. Verg. De Jonge IV p. 160.

? Verg. de Jonge IV p. 142 en 143, waar Dirk Jemming wel, en Dokter de Haan niet genoemd wordt. 
syn van 't Christen bloet daerom soude vergooten werden, doch daerop en wart niet geantwoort. ${ }^{1}$

Den $30 \mathrm{~d}^{\circ}$ wert noch een missive van de Engelsen binnen 't fort gevonden bij de sommighe van hen onderteeckent ${ }^{2}$ bijnaer van selven inhout als voren, daer op van binnen geantwoort wert, de hare wel ontfangen hadde, dan alsoo niet en wisten of 't uwt den name van Tomas Dael ofte haer geeste waere, en conden hen gheen antwoort geven, tensij daervan nader verseckerheijt waeren, ende de hanttekeninge van den Generael selver sagen, 't welck soo geschiede, soude dan int corte antwoorde, wat gesint waere te doen ofte niet. Tegen den middach wederomme een andere mesive binnen gecomen bij Tomis Dael en den raet onderteeckent, daer in hij als vooren 't fort in sijn handen eijschten voor en alleer sijnne baterie speelde en eenich bloet gestort worden, belovende alle lieden van wat natije, dat sij waren, het leven te laeten en voor overlast der Javanen te bevriden; doch soo jimant van de Hollanders vriwillich wilde dienen, soude genieten alle en alsulcke gagie als te vooren verdient hadden bij de Vereenichde Nederlanse Comp. ende daerenboven 2 -maenden op de hant vereert worden; verclaerde voorts dat sulcx tusschen hen en den Coninc van Jacatra alsoo geaccordeert was, ende datse derhalven al 't gene belofden getrouelick souden houden en naercomen, begeerende hij erop cito antwoort wederomme, ofte daer naer en souder geen bloet verschoont worden; begeerende oock datter imant wt het fort met hem soude comen sprecken, datter weder van haer syde een in ostagie soude blijven. Onder stont Widiak Prama en Tomas Daele.

Den breden raet hierop geropen ende vergadert synde, is in bedencken gecomen, hoe nu beyde de Engelsen en Javanen

1 Bij B I „Den selven ditto [29Dec.] hebben d'Engelssen verscheijden brieven in Engels met pijllen int fort geschooten, waer van 5 geoppent, aijsten sonder fondement presentelijek secker conditien om in gevalle wij daer in niet wilden verstaen haer te connen voor alle rechterren onschuldigen, protesterende geen oorsaeck te wessen van het cristen bloodt datter vergoeten soude mogen woorden, met meer suberbiusse drijgementen meer, daer d'onsse ongeraden vonden op t'antwoorden".

9 B I zegt: ${ }_{n}$ Den $30^{\text {en }}$ ditto sondt den Engelsssen admirael Thomas Dael noch een missive binnen $t$ fort van de vorgande inhoudt, dan also deselvighe niet ondertijokent was, sonden die vant fort deselvighe wederom, seggende onnodich te sijn op sulcke briven te antwoorden". 
macht tesaem gespannen waren om sonder langer te toeven ' $t$ fort aen te tasten, te rinueere, waertoe alreede hare baterie met geschut beplant, met volck voorsien ende hunne vaendelen opgherecht syn; oock als vooren niet meer cruijts en hadden, als wel in een dach, siso 't hart aen ging, soude connen verschieten, ende daarom niet continueeren noch haer verhinderen conden, veel min resisteren tot de comste van d' $\mathrm{H}^{\mathrm{r}}$ Generael, 4 manden lang. Oock veel ingevallen volck hadden; 't volck oock 't arbeyde moede waere en niet soo gewillich, als wel behoorde; de huijse noch niet met aerde gevult, noch het fort niet deffencibel; darhalve uwt nootsacke geresolveert wert d'Engelsen op haer begeerte te hooren, sulcke goede conditie te bedingen als doenelijck was ende haer de forteresse te laeten, liever met de cristenen als met de heijdenen te handelen, daertoe sij verclaeren, haer nochtans niet en verstonden wt lichtvardicheyt, maer wt noot gedrongen sijn, ende voor des tijt niet beter mogende genotsackt haer leven ende eenige der onderdanen te salveren, waerdoor noch naderhant de Comp eenige dienst soude mogen gheschieden. Actum $30^{1} \mathrm{Janu}^{\circ}$ $a^{\circ} 1619$. Was onderteeckent by 20 personen ende medestemmige van borgerie.

Adj. $31 \mathrm{~d}^{\circ}$ 'smorgens is uwtten name van de Engelsen binnen 't fort gecomen $\mathrm{M}^{\mathrm{r}}$ Wadden, ${ }^{2}$ soone van den Gooverneur van Pleymuijden, ende in syn platse is aen d'Engelse gecommiteert Jan van Gorcom, capp $^{n}$ met volle commissie om met den Generael Tomas Dael, in presentie ende wtten [name] van den Coninck te tracteeren, sooals bij gemeyne resolutie gearresteert was, en soude connen doen. Maer voor den raet ende in 't hoft comende, en conden dien dach niet accordeeren, soo dat sonder iets sonders te verrichten weder gescheyden ende int fort gecomen is.

Den anderen dach, den eersten Febrij, op 't versock van d'Engelsen andermael voor den selfden raet int hoff gecompareert synde, naer langer ende veel handelen syn wederomme ghescheyden; doch nae den middach tegen den avont ten derdemael vergadert synde, syn eens geworden en met malcanderen de volgende punten gearresteert, toegeseyt ende on-

1 B II maakt de drukfout 20 Januari.

2 Weldin of Welden, vroeger chef van de factorij op Djambi. Purchas 1905 V p. 123. Deze kon „fray duits spreken”. Verg. de Jonge IV p. 144. 
derteeckent; 1. dat het fort, volck en ammonitie van ooreloge aen d'Engelsen en het contant, coopmanschappen ende andere juelen aan den Coninck souden gelevert worden; 2. dat d' Engelsen aen de Hollanders souden bestellen een schip, dat hen van de contanten binnen $\mathrm{t}$ fort synde bij den Coninck tot 2600 realen soude betaelt worde, goet en bequaem tot hare voyage, versorcht met 4 goede stucken, 50 mosquetten en 20 pijcken, oock met goede seylen, anckers, touwe en victualie voor 6 manden tijts met vrie liberteijt ende lesencie om te gaen naer de custe van Coromandel ofte daer hen soude believe, wtgenomen naer Amboyna ofte Mollucques; 3. dat alle cristenen int ' $t$ fort sinde, sullen liber en vrij syn van wat natie sij oock mochte syn en soude meugen wt het fort drage alle partickeliere goederen ende in contant de somma van 6200 realen, daerenbove mits hare persoonen en goederen voor eerst te transporteeren aen eijlande van Jacatra, sonder nochtans van Javanen ofte imandt anders in 't minste beschadiget te worden; 4. de Hollanders sullen gehouden sijn eenen dach naer teeckeninge deses wt het fort te vertrecken en die gene noch ongecristent ware soude daer binnen blijve, ${ }^{1}$ wtgesondert de Japponesen; 5 . alle,

1 Door De Jonge, Dl. IV p. 145 is uit het dagregister van Melis Remmerts weggelaten de volgende teekenende bijzonderheid:

... . maer doen Joseph Janssen de Natlaer dit hoorden, dat de Coninck van Jacatra alle de swarten hebben soude, die niet gedoopt en waeren, het sij man ofte vrouwen ende kinderen, die soude den Coninck aentasten, doen ginck Joseph Janssen de Natelaer bij $\mathrm{S}^{r}$ Raeij ende den domine ende vraechden den domine of hem wẹl beliefden sijn twe slavinnen te doopen, dat hij niet geerne en hadde dat die twe slavinnen inder Javanen handen coomen souden, soo veer als hij het schutten conde. Doen seijde den domine: wilt ghij die slavin trouwen dan soude ick se wel doopen, maer nu mach het niet geschien, oft sij mosten coomen ende onderrechten mij met de schrift. Doen vraechden Joseph Janssen de Natlaer oft hij se wel wech schencken mooht. Sij seijden ja dat het sijn was; hij mochtse vercoopen oft wech schencken soo het hem beliefde te doen. Ende doen ginck Joseph Janssen de Natlaer ende schonck de twe slavinnen aen den Engelschen coopman, omdat de twe vrouwen inder Javanen handen niet coomen souden ende, enz.

En eveneens, op pag. 148:

Adij 10 Dito [Februari] op een sondach doen begonden wij ons goet weer booven te draegen, omdat het groote pachuis verstuwt soude worden. Doen seijde Pr Raij met den domine dat Joseph Janssen de Natlaer sijn twee slavinnen wederom van den Coopman nemen soude, den Engelschen Generael conde sijn woort niet houden ende dat Joseph Janssen sijn woort oock niet houden soude ende tasten de slavinnen weder aen. Doen seijde Joseph Jansen de Natlaer: ick hebbe de twe slavinnen aen meester Wattel geschoncken, ick 
die machtich waren geweer te voeren en oock mede gevangen persoonen, sullen gehouden syn van dato tot $p^{m o}$ November geenen dienst tegen d' Engelse Comp $\mathrm{p}^{\mathrm{a}}$ te mogen doen, en souden oock de gevangenen vrij gestelt en gelaeten werden als d'andere binnen 't fort; 6 . datse soo lange de Hollanders met hare goedere aen d' eijlanden hun souden onthouden en het beloofde schip niet veerdich waere, aldaer door 2 Engelse scheepen souden tegen een Javaense overlast bevridt worden; 7. 't voorges. schip soude, binnen 15 dagen ten langste, veerdich syn en dan de Hollanders met een vriepas van den Generael om voor alle Engelsen ontmoetende schepen bevrit te syn soude vertrecken. Uock soude van de Hollanders van dato tot dattet fort soude gelevert syn, wtgaen 12 van de voornaemste persoonen, te weten $\mathrm{P}^{\mathrm{r}}$ van Raij, den predicant, 2 ondercooplieden, 2 assistenten, 1 cergeant ende 4 constabels en wederomme daer binnen blijven 4 orong kais en 4 Engelse cooplieden, eer de capp ${ }^{n}$ en de rest daer soude wttrecken. Souden ook geene Javanen mogen int 't fort comen, soo lange de Hollanders daer noch inne waere, dan alleen de 4 . tot de visitatie gecommitteert. Actum primo Febr., onderteeckent bij den Coninck, Tomas Dael en sijn raet en bij die van 't fort voornd. '

Mondelinghe woorden geaccordeert, dat d'Engelsen haere boots soude senden voort fort, om de persoonen ende goederen te lossen en aen hen schepen en van daer aen de eylanden te voeren; oock dat alle persoonen tot den lichame toe souden mogen ondersocht ende hen goederen altemalen gevisiteert worden, en dat niemant, groot noch cleyn, en soude mogen wtvoeren boven tgene sy alreede per inventaris over gegeven hadde, want seyden te weeten, datter diemanten en juelen binnen ware gecomen met 't fergadt van Succadana.

can dat niet doen ende nemen se weder. Doen seijde $\mathrm{S}^{r}$ Raij: wilt ghij se niet weder nemen soo sullen wij se aentasten. Doen seijde Joseph Janssen: dat moocht ghij doen, ick wil geen man van twe woorden wesen, wech te schencken ende dan weder nemen, maer hadde den domine haer willen doopen ick en hadde de twe slavinnen niet wech geschoncken.

Adij 12. dito op een dijnsdach doen héeft $\mathbf{S}^{r}$ Raij den Engelschen coopman, genaemt meester Wattel, de twe slavinnen weder afhandich gemaect ende liet de twe slavinnen met Anselien boven in de $\mathrm{H}^{r}$ Generaels camer slapen, omdat sij niet meer bij meester Wattel coomen souden.

1 Het andere dagregister geeft verkeerdelijk 31 Januari 1619 als de datum van het contract, De Jonge IV p. 144, 
Ende alsoo dese handelinghen een groote swaricheijt en droffenisse onder ider veroorsackte, is noch vóór de overleveringe ende geteeckende acten den breeden raet wederom vergadert, ende niet tegenstaende de ellenden, die ons aenstonden, hochlijck werden overwoogen, nochtans den dringende noot daerbij. vergeleecken synde, werd eendermael geresolveert als vooren, wenschende Godt een genadige revenge $\mathrm{t}$ sijner tijt gelieft de $\mathrm{E}$. $\mathrm{Comp}^{\mathrm{a}}$ en de haere te verleenen.

Soo haest de acte bij beijde pertijen onderteeckent ende binnen 't fort gecomen was, syn lyber en vrij vertrocken $\mathrm{M}^{\mathrm{r}} \mathrm{Jnes}^{1}$ en $\mathrm{M}^{\mathrm{r}}$ Smet, Engelse cooplijeden, ontrent 8 dage voor den aenvang van den oorelooge om seckere reede by $\mathrm{d}^{\prime} \mathrm{H}^{\mathrm{r}}$ Generael aengehouden, doch is $\mathrm{M}^{\mathrm{r}}$ Wadden, gedeputeerde, binnen gebleven om met de anderen 12 des anderdachs aen de schepen te gaen.

En alsoo niet anders gesien en was, off souden de fortresse hebben verlaten, en oock alles ten naeusten ondersocht en gevisiteert worden, syn die van binnen genootsackt geweest, de boecken van de Vereenichde comp ${ }^{\mathrm{a}}$ ende veel andere stucken, die vreese onder hande van d'Engelssen tot grooten nadeele van de Compa ende de Generael mochten sijn, int vijer te werpen ende te verbranden, volgens oock de commissie hen bij den $\mathrm{H}^{r}$ Generael op syn vertreck schriftelijck geordineert.

s. Syn oock eenige schenckagie van silverwerck aen Tomas Dael gedaen op hoope van jets meerders mede te gewinnen, waerover oock beloofde, boven de geaccordeerde stucken noch 2 , ende vaten cruijt te sullen bestellen wt syn eijgen schip, en 't silverwerck weder te sullen vereeren, seggende geen taffel provisie en begeerde te nemen.

1 Wellicht Jones? 


\section{VERVOLG VAN HET UITGEBREIDER JOURNAEL VAN VAN DEN BROECKE. (B I).}

Den $2^{\circ}$ ditto [Februari 1619] 's morgens vroech waren de Engelsse boodts al voor $t$ fort, dan alsoo die vant fort noch geen verseckerhijt hadden, wilden de Engelssen noch niet te spraeck staen.

Den selvden ditto naer middach quam den Tommegon van Bantam wel met 2000 man ende $\mathrm{S}^{r}$ Cornelis Houbrack van wegen den Pangeram ofte Conninck om mij op mijn versoeck met gewelt daer te brengen, soodat die vant fort naer dat tselve verstonden van contract met de Engelssen noch Conninck tot Jaccatra gemackt niet en hielden, voor en aleer sij mij liber en vrij leverden; soo dat ick den selven avont noch verbij het fort met een vendel connincks prauwen naer Bantam gevoerdt wirdt.

Soo hast den Tommagon bij den Conninck van Jaccatra quam omringelden hem met sijn volck en trock sijn cridts uijdt vragende hem ${ }^{*}$ off gecridts wilde wesen off sijn landt aen den Pangeram van Bantam over leveren, die geen beeter middel sinde $t$ leven voor den doot gecossen heeft, ende als een slaeff met een vrouwe ende jonckste soon sijn landt over gaff ende verliedt, dat aen den Conninck van Bantam datelijck geaijgent wirdt ende de possessi daervan nam.

Infien de Engelssen vonden haer bedrogen; sijn daatelijck seer verslagen met alle haer volck ammonitie van orloghe dat mede voeren conden naer boordt gevaeren, ende doen niet beeter coosten, vermanden ons volck tot couragi, presenterende hun liever assistentie te doen dan haer in de ongelovighe Javanen handen te geven, versochten daerenboven aen die vant fort vrij gelijde om haer schudt met hun boodt verbij $t$ fort naer boordt te mogen brengen, hetwelck hun vergunt wirdt om veel reeden.

Den $3^{\circ}$ ditto 's morgens quamen wij tot Bantam alwaer in den Sabandaer's Quaij Maes ${ }^{1}$ huijs seer strengelijck bewart ben geworden.

\footnotetext{
1 Kjai Warga,
} 
Apriel $A^{\circ} 1619$.

Adi den 4 ditto arrivierde voor Bantam een Chinesse jonck, die in 56 daghen daer uijdt China gecommen was, die van de Engelssen aengehalt wirdt en geplundert.

Den $6^{\text {en }}$ ditto arrivierde daer een jonck van Patannja met rijs, door den oppercoopman Druijff voor Jaccatra affgedespatciert, die de Engelssen met noch twee Chinesse joncken rijckelijck gelaaden meede aenhalden ende altsamen plunderden, dat int gesicht van die van Bantam.

Majo $\mathrm{A}^{\circ} 1619$.

Den $14^{\mathrm{e}}$ ditto een misive uijdt fort Batavia (als wij hadden laaten $t$ voors. noemen) becommen van de oppercooplieden Pieter de Carpentier ende Andries Soury, die den $10^{\text {en }}$ derselve met het fargadt Selon daer gecommen waeren, om tot de compst van de E. Heer $\mathrm{Gen}^{1}$ te commanderen.

Den 28 ditto arriveerde de E. Heer Gouv ${ }^{r} G^{\text {al }}$ oock op de reede van Jaccatra uijdt Amboina met 17 scheppen als te weten, de Trouw, de Soon, ${ }^{1}$ Harlem, Suijder Eendracht, Gouden Leuw, t Wappen van Amsterdam, Oud Hoorn, Bargerboodt, Morgenstarre, Engel, Neptunus, Nassouw, t Hart, de Jager, Sante Migiel, Tieger ende $t$ fargadt Selon.

Den $29^{\text {en }}$ ditto is de Heer Gen ${ }^{\text {al }}$ met al de soldaten ende partij boodtsgesellen naer landt gegaen ende order gestelt omme de stadt Jaccatra te vermesteren.

Den 30 ditto 's morgens is de stadt Jaccatra Godtdanck sonder eenighe wederstant ofte verlies van volck ingenommen, vermidts alle de Javannen gevlucht waeren. D'onsse warren starck 12 vandellen, soo soldaaten als boodtgesellen, waer van 2 dooden hadden ende van de Javannen 3, soodat meester van de stadt met d' hulpe van Godt gebleven zijn.

1 Lees: „Son". 


\section{Bijlage III.}

Resolutien van

Generaal en Raden

1613-1620.

Kol. archief.

Maandag ady 22 October 1618. In 't schip 't wapen van Amsterdam liggende bij de eijlande Jaccatra.

Alsoo de voorgaende resolutie in dato 31 Aug. laastleden tegen des mislukte moordadigen aanslag des Pangerangs van Bantam, de Coning van Jaccatra ende consequentelijk het gantsche land van Java bij den Heer President tot verzekering van des Comp. rijke middelen en 't leven van hare dienaren genomen, een zaak van zeer groot gewigte is, daar niet alleen de behoudenis van deese plaatse maar ook den algemeenen welstand van de generale comp $\mathrm{p}^{\text {ie }}$ in India aan dependerende is; daarenboven bij dagelijkse ervaring gewaar worden, dat den mislukten aanslag, die op 20 Augustus passato onder het belijd van den Pangerang Gabang alhier in deese logie geattenteert ende in effect zoude gebragt zijn geweest, so den Almogende zulks niet sonderling tegengehouden ende belett hadde, bij deese trouwlose moren niet alleen niet aan een zijde gesteld en vergeeten, maar ter contrarie wederom op verschijde andere manieren herhaald ende onderstaan en dagelijks nog meer en meer hervat worden sal.

So is 't dat de E. Heer President ende zijnen Raad op den 19 dezer hebben goedgevonden de sake in een algemeene vergaderinge van alle oppercoopluijden, schippers ende krijgsofficianten, hier omtrend tegenwoordig zijnde, voor te dragen ende den eerste oorsprong, redenen en voortgang van die te resumeeren :

Eerst ende alvoorens den aanvang en 't progres van deesen moorddadigen anslag in 't breede bij den Heer President de vergadering voorgedragen en al de omstandigheden van dien van punt tot punt wel ontleedt zijnde, is eijndelijk naar rijpe deliberatie met een algemene toestemminge gelijk bij de schriftelijke advijsen, hier onder is blijkende, goed ende hoognodig is bevonden, dat men met de versterking van onse logie tot Jaccatra gelijk die alreede bij de Heer President ontworpen is, om te zien hoe de zake hem zoude toedragen, voortvaren ende tegens alle geweld in volkomen defensie brengen sal:

Willem Jansen, oppercoopman tegenwoordig op 't schip 't 
Wapen van Amsterdam advijseert dat men de plaatse van Jaccatra sal versterken ende het begonnen werk naar gelegendhijd voltrekken. (ondert.) Willem Janssen.

Isebrand Cornelisz, schipper op 't schip Mauritius, segt mede de plaatse van Jacatra met gemak te versterken (onder stond) Isebrand Cornelisz.

Claas Gerritsz, schipper op 't schip Nassouw, dat men de plaatse van Jaccatra sal soeken te versterken om onse goederen te versekeren (ondert.) Claas Gerritsz.

Willem Dirksz, schipper geweest op het schip Hoorn advijseert dat men de plaatse van Jaccatra tot versekering van des Comp. goederen zal versterken (ondert.) W. Dirksz.

Leendert Jacobsz, schipper tegenwoordig op 't schip St. Michiel advijseert als voren dat men de piaatsen van Jaccatra sal sien te versterken (was ondert.) Leendert Jacobz.

Willem Jacobsz, schipper tegenwoordig op 't schip den Engel geeft mede voor advijs de plaatse van Jaccatra met den eersten te versterken tot versekering van lijff en goederen (was onderteekend) Willem Jacobsz.

David Davidsz, schipper op ' $t$ jagt den Jager van gelijke, dat men de plaatse van Jaccatra sal versterken (was ondertijkend) David Davidsz.

Jan Willemsz, schipper op 't schip de Neptunus advijseert dat men met den eersten de plaatse van Jaccatra sal versterken (was ondert.) Jan Willemsz.

Gerrit Douwesen, schipper op 't schip de Trouw geeft voor advijs dat men ons tot Jacatra metter haast sal versterken eer de scheepen vertrekken, ende met alle man van de schepen daar aanvallen. (was onderteekend) Gerrit Douwesz de Vries.

Claas Hermansz schipper van de Zuijder Eendragt advijseert de plaatse van Jaccatra metterhaast te versterken tot onse versekering om met hulp van scheepen eer die vertrekken te eerder klaar te weesen. (was ondertekend) Claas Hermansz.

Jan Cornelissen Kunst, schipper op 't schip Delft so haast mogelijk is de plaatse Jaccatra op te maken en onse stand te versekeren (was ondert.) J. Cornelissen Kunst.

Florús Heeres, schipper op 't schip de Bergerboot geeft voor advijs dat men de huijsinge van Jaccatra sal versterken en dat hoe eerder hoe beeter. (was getekend) Flores Heeres:

Hans Rogiers, oppercoopman tegenwoordig op 't schip de 
Trouwe advijseert, terwijle hier de scheepen bij den anderen sijn, ons tot Jaccatra te versekeren (was onclertekend) Hans Rogiers.

Daniel van der Heggen, oppercoopman, tegenwoordig op 't schip de Zuijder Eendragt met het begonnen werk voort te varen tot dat versekert zijn (was ondertekend) Daniel van der Heggen.

Juan Vernat, oppercoopman op 't schip den Engel, advijseert met den eersten met de zake van Jaccatra voort te varen tot ons versterking (was ondert.) Juan Vernat.

Pieter Dirksz, oppercoopman, tegenwoordig tot Jacatra, advijseert, dat men het begonnen werk al sagtgens sal voortvaren tot den tijd en wijle die van Jaccatra onderstaan enige verhindering te doen als wanneer met alle man daar aan kunnen vallen (was ondertekend) Pieter Dirkszoon.

Franco van der Meer, oppercoopman op 't schip Delft, dat men ons beter tot Jaccatra soude verseekeren en al sagtgens met het begonnen werk voort te varen (was ondert.) Franco v. d. Meer.

Hendrik Lievensz. van Amb. en de tegenwoordig tot Jacatra wesende advijseert dat men het begonnen werk tot Jaccatra voort sal varen ende meer soldaten aan land zetten. (was ondert.) H. Lievens.

Abraham Strikker sergeant, tegenwoordig op 't schip Delft, advijseert ons tot Jacatra metter haast te versterken (was ondert.) Abraham Stricker.

Abraham Jansz Morings sergeant, tegenwoordig op 't Wapen van Amsterdam, geeft voor advijs met het begonnen werk tot. Jacatra voort te varen al soetgens (ondertijkend) Abraham Jansz.

Dirk Reiniersz sergeant op 't schip Delft advijseert ons met den eersten te versterken (was ondert.) Dirk Reiniersz.

Arend Maartsz, commandeur, tegenwoordig op 't schip St Michiel geeft voor advijs, dat men met het werk tot Jaccatra voort sal varen en dat met zulken neerstigheijd als mogelijk is. (was ondert.) Arend Maartsz.

Pieter de Carpentier, opperkoopman tot Jaccatra, dat men de begonnen punct eerst in zijn volkomen effect zal zien te stellen en so daar tegen geen oppositie valt, alsdan met gemak voort te varen sonder extraordinaire commotie te betoonen. (was ondertekend) Pieter de Carpentier.

De voors. advijsen gegeeven zijnde heeft de Heer President 
de vrienden daarvoor bedankt ende verklaart dat de stemmen naarder gecolligeerd ende met de zake voortvaren zal in maniere en voege, als zig den tijd ten besten van de generale Comp. gedragen zal.

Actum ut supra en was ondertekend

Jan Pietersz Coen. Thijs Cornelisz Vleeshouwer, secretaris. 


\section{Bijlage IV.}

Resolutien van

Generaal en Raden

$1613-1620$.

Saturdag ady 25 Mayo 1619.

Kol. archief.

Also van Jaccatra verstaan hebben, dat apparentelijk was de Engelsche vloote ons niet verwagten zal, zijnde zeer desolaat van volk, tweedragtig onder den anderen ende ook alreede na den roep ging, van den andere verdeijlt, preparatie maakte in 't geheel door te lopen, is door den Heer Generaal geproponeerd om tijd te winnen, hoe zijn E. voor desen is genoodsaak geworden om lijff en goederen te salveeren, de plaatse van Jaccatra te versterken en tot een volkomen fort te maken; want alzo bij de Javanen en Engelse tegen ons verschijde lagen leggen ende verraderije onder een vriendelijk gelaat gepractiseerd, onderleijd en door Gods genade mislukt waren, hebben sij lieden verschijde bolwerken rondsomme onse huijsen begonnen, om dito huijsen van Jaccrata daardoor met geweld van groff geschut te vermeesteren, welke bolwerken zo behendiglijk zo verre gebragt zijn, dat er enig .grof geschut jegen ons geplant was en gewaar wierde wat men tegen ons voorhadde, zo dat er tijd en gelegenthijd ontbrak om onse goederen van land te scheepen ende dat met geweld haren werken hebben moeten verhinderen, selfs eer veerdig waren om geweld met geweld te weeren, dewijl een goed deel van de plaatse van 't begonnen fort nog open was en dat merendeel niet schootvrij van groff geschut of de vijanden zouden ons meester geworden zijn, eer tot enige defen sie hadden konnen komen; dat nu ter contrarie door Gods genade anders uijtgevallen is, ende zo men nu van meninge is, het regt te gebruijken welke ons de Almogende God tot Jaccatra gegeven heeft, ende goed vind de plaatse meerder te versterken, vorder in te houden ende tot een generaal rendevous te gebruijken, moet men considereren, dat het dan van node wesen sal een generale landtogt op de stad ende in 't land van Jaccatra te doen, zo om een vrije ruijme posessie ende jurisdictie in 't land te bekomen, als voor te komen, dat de riviere niet verlijd worde, gelijk gesegd word, die van Bantam (welke den Coning van Jaccatra onder pretext van die tegen ons te adsisteren verdreven hebben om ons met de zijne geusurpeerde authoriteijt te previnieeren en dwingen) voor hebben te doen. Ende also het nodig is eer men zo een gewigtige zaak aanvange ofte het regt en de goede occasie versuijmen, dat alle aankleven van dien rijpelijk over- 
wogen, geconsidereerd ende gedebatteerd worde, heeft de Heer Generaal den Raad aangediend, dat haar E. gelieve te overwegen de importantie van de laatste, ende of men verder zal aanvangen de plaatse van Jaccatra tot een generale rendevous t'appropieeren, dan oft verkiesen ende gebruijken zullen ene van degene, die lange voor deesen voorgesteld zijn geweest, als namentlijk een van d'Eijlanden van Jaccatra off andere in de straat Sincapura gelegen, off elders aan 't vaste land, van alle welke de Heren Majores meest tot Ontong Java inclineren, dog zijn Excell. de Prince van Orange schijnd meest tot een bequaam Eijland (als er een bequaam te bekomen is) genegen te wesen, om zijn E. ter naaste vergaderinge haar advijs te geeven en finale Resolutie op de zake te nemen. Interim is goedgevonden, dat alle behoorlijke preparatien maken ende goede ordre stellen zullen, opdat men voors. landtogt sonder dilaij doen mag, zo haast met de vloote voor Jaccatra komen, wel te verstaan zo d'Engelse vertrokken zijn ende zo het dan also goedgevonden word, en om tijdelijk naarder informatie van alle gelegendheden van Jacatra te bekomen, ende de onse aldaar van onse desseijnen te verwittigen opdat zij haar ook vaardig houden, is gearresteert, dat dadelijk 't jagt 't Hert voor uijt na Jaccatra senden ende van daar bij ons ontbieden zullen Pieter de Carpentier, Pieter van Raay, Evert Harmansz ende de capitain off lieutenant van 't fort. Voorder met de krijgsraden gelett wesende, dat in de vloote sterk zijn omtrend 1220 coppen, is goedgevonden, dat daarvan de twee derde landen zullen, ende dat die met volk van Jaccatra in derthien comp. elk'van omtrend 70 koppen verdeelen zullen en dat onder navolgende hoofden ende ordre.

Sergeant majoor capit ${ }^{\mathrm{n}}$ Hietveld 15 coppen uijt Hoorn. Lieut. Jean Elias . . 20 coppen uijt de Trouw. Vaand. Sebalt Wonderaar de rest uijt ' $t$ fort.

\begin{tabular}{|c|c|}
\hline Overste $\mathrm{S}^{\mathrm{r}}$ & Capt. Jan Jansz v. Gorcom. 40 uijt de Sterre. \\
\hline Overste $\mathrm{S}^{\mathrm{r}}$ & Lieut. Abrah. Strijker. .10 uijt Hollandia. \\
\hline Jacq. le & Vendr. Hend. Hermansz . 9 uijt de Zon. \\
\hline Febre & Capit. Meijer. . . . 40 zijn eijgen volk. \\
\hline de avant & Lieut. Jan Jansz Hoogland. 36 uijt de Bergb. \\
\hline & Vend. de Wilde .... \\
\hline & $\begin{array}{l}\text { Cap. Hendr. Bruijstens. } \\
\text { Lieut. van den Berg. } \\
\text { Vend. Jaque Coetelij }\end{array}$ \\
\hline
\end{tabular}




deEd.Heer
Gener.
Coen de
batailje. $\quad \begin{aligned} & \text { Capit. Wouter Heuten } .32 \text { van zijn eijgen volk. } \\ & \text { Lieut. Jacob van Markt } .36 \text { van de Eendragt. } \\ & \text { Vendr. Jan van Houdaan. } \\ & \text { Capit. Daniel van Heggen } 52 \text { van St Michiel. } \\ & \text { Lieut. Abraham v. Uffele. } 22 \text { van Nassau. } \\ & \text { Vendr. Jacob Leendertsz. } \\ & \text { Capit. J. Leendertsz. . } 70 \text { uijt de Trouw. } \\ & \text { Lieut. Wijnand Brantsz. } \\ & \text { Vend. Jan de Brasser } \\ & \text { Capt. Gheen Huijgen . } 70 \text { uijt de Leeuw. } \\ & \text { Lieut. Daniel Wolff. . . } \\ & \text { Vaand. van Zuijlen . . }\end{aligned}$

Capt. Jan Willemsz. Gonale ... 20 uijt d'Eendragt. Licut. Willem Tonissen . . . . 17 uijt de Zon. Vend. Anthoni Coen. . . . . 25 uijt Haarlem.

4 uijt den Engel.

Sergeant majoor capt. Jan Pa. . . 42 uijt Haarlem. Lieut. Andries Gabriel . . . . . 28 uijt de Zeewolf.

Vend. Gillis Venant

Captijn Theunis Floresz. . . . . 50 coppen uijt de Zon.

Lieuten. Barend Milters . . . . . 18 van de Jager.

Vaandrig Caver.

Capitijn van der Dussen. . . . 48 uijt Hoorn. Lieut. Floresz. . . . . . . . 22 uijt 't Hert.

Vendrig Fredrik Fredriksz .

Aldus gedaan in 't schip de Trouwe, datum ut supra, omtrend Cheribon in zee ende was onderteekend:

J. P. Coen. Laurens Reaal, sonder hierdoor te emologueeren die dingen, daar ik om, nog omtrend en ben geweest. Steven van der Hagen. Willem Janssen. Franco van der Meer. Jacques le Febre. 


\section{Bijlage V.}

Rijksarchief.

Register van de brieven

en papieren, overgecomen

in den jare 1620 .

Boek I. Fol. 264.

Corte antwoorden op het interrogatorium bij ordre van den Generael Coen de raden van 't fort Jacatra gepreponeert.

Het is kennelijck, hoe de $\mathrm{H}^{\mathrm{r}}$ Generael Coen, d'oorloghe tegen den Coninck van Jacatra omme de Javanen af te houden, ende also des.Comps wooningen, volck ende goederen, soo veel doenlijck waere, tegens hen gelooft te versekeren, op 23 Decemb. 1618 voorgenomen ende aengevangen heeft, dan soo alle tijt hebben vermeijnt niet so seer omme ten wtersten wt te voeren, dat is sonder ophouden te continueren, als wel, gelijck mede door de nieuwe oorlooge bij hen ende sijnen. Raet op andre plaetsen mede aengegaen, omme d'inwoonderen, naer gedaene vraecke ende aengecondichde vreese, tot eenen beteren ende vaster vrede te constringeren; want blijct dit $1^{\circ}$ wt de missive 3 ende $18 \mathrm{Janua}^{\circ}$. passato aen 't fort gesonden, daer inne wel expresselijcken van vrede tot contracteeren mentie gemaect wort; ten anderen in cas (onses bedunckens) de E. comp door het voeren van offensive oorlooge hier ter plaetse niet veel profiteren, maer eer merkelijcke schade becoomen, gelijck de bevindinge leert, Soo oock mede het eene gewelt oorsaecke is dat het ander hem oock verheft, can oock mede wel het meeste het geringste alsoo benauwen, dattet niet geraden is, stilstant aengebooden sijnde, te refuseeren ende als ongemerct verbij te laten gaen.

Op het $2^{\mathrm{e}}$

Soo gevraecht waere, waeromme met den Coninck van Jacatra in stilstant van wapenen getreden sijn, souden beneffens de voorverhaelde redenen oock deese connen bijbrengen. 1 . Om de Engelsen te jalouseren ende van hun wit ende dissensen aff te brengen ende haeren ovaerdgyen pracht te controleeren, wel wetende, datse sonder permissie van den Coninck tegen 't fort te lande niets en conden wtrichten ende daer toe te water oock gants gene gelegentheijt en hadden; 2 . omme de vrientschap 
van de Coningen, beijde van Jacatra ende Bantam, de behoudenis van de comptoijren hier ontrent ende 't welvaren van gevangene vrienden te behouden, ende soo veele doenlijcken waere te bevorderen; 3 . omme bequaemheijt te hebben d'aenstaende en comende schepen wt patria ende andre quartieren alle gelegentheijt te mongen advijseeren, ende d'Engelsen handel te meerder bekent te worden; 4 . omme tijt te ghewinnen ende goede gelegentheijt te obtineeren omme 't fort te verstercken, ende ijegens viants gewelt suffisant te maken, daer buijten anders (gelijck het interrogatorium wel seit) souden gedwongen worden tot een erger, tot het welcke alle door den oorlooge verhindert wierden; 5 . omme dat rondelijcken is gepreponeert geweest, bij den $\mathrm{E} . \mathrm{H}^{r}$ Generael geordonneert was, beter ware met de Javaen dan met d'Engelsen in vrede oft handelinge te treden, doch schijnt bij abbuis alsoo geschiet te sijn.

Dan alsoo gevracht is, waerom corts naer 't vertreck van den E. $\mathrm{H}^{\mathrm{r}}$ Generael aen den Coninck van Jacatra 5000 realen spetij ende een aen cleden gegeven hebben, antwoort sulcx geschiet te sijn: 1. omme dat den Coninck claegde door d'aengedaene oorloch groote schade geleden hadde, verclarende oock alrede 4000 realen verbeurte te sijn doordien buijten sijnen wille ende believen in sijn lant met d'Engelse oorlooge gemoveert, sijn rijck geturbeert ende aen sijne conincklijke reputatie benomen hadden; daerbij doende, hen verscheijden mael bij den E. $\mathrm{H}^{\mathrm{r}}$ Generael voort het wttmueren van de catte buijten oude contract gedaen, betalinge ende contentement te doen, gepresenteert was; 2 . omme in contra te preserveren alle de costelijcke packen cleden, soo voor als naer 't vertrecken van den $\mathrm{E}$. $\mathrm{H}^{\mathrm{r}}$ Generael ter defensie op de pointen voor borstweringe gebruict, diens waerde d'oncosten prefereerde; 3 . om te becoomen den vrijen marctgang, daeraen om der siecken, braq waters ende andere redenen willen vele gelegen waere; 4. omme d'Engelsen te verhinderen in 't opbouwen van nieuwe godong ontrent de plaetse alhier, gelijck bij de Cooning belooft was; 5 . omme mede voor te coomen d'oncosten van 't bestedigen van eenige niewe wercken, die dicwils met haest ende groot perijkel mosten opgemaect worden.

Dit alles is niet strijdende, maer accordeert met de missive adij 18 à 28 Junij' aen 't fort gesonden, daer inne ontbooden

1 Lees „Januari”. 
was geene oncosten aen te sien, om met yemant [van de] pertije tot de comste van de vloot in accoord te treden, ende hen van alles hier passerende te advijseeren.

Hoe wel dese handelinge nu, naer d'uijtcomste geoordeelt, eenen valschen vrede genoemt wort, strijt sulcx nochtans tegen de goede intentie dergener, die binnen het fort sijn geweest ende oock, soo apparent is, tegen de wille des Coninx van Jacatra, die naerderhant in d'ongenade des Coninx van Bantam vervallen is, alsoo beijde pertijen abbuserende, 't welck oock den besten kan overcoomen.

Op het $3^{\mathrm{e}}$.

De wtwendijghe versekeringe was des Coninckx eijgen hanttastinge ende ondertekeninge in onser ende andre orang kaijen presentie ghedaen; d'inwendijge was de bedenckinge van de weijnich profijten, die den Coninck ende voornementlijck sijne onderdanen wt het oorloogh hadden te verwachten, ende de vreese van de aenstaende vloote, die te volgen stont. Van den Coninck van Bantam en conden gene versekeringe eijsschen, alsoo hem veinsde met de saecke niet te willen bemoijen.

Op het $4^{e}$.

Wort gesegt sulx goet gevonden is, omme de goede aliantie bij den Coninck te vooren gehouden te vernieuwen, ende d'inwoonderen van de sinceriteijt der nieuwer vrede te versekeren, en de ourang kaijen van Bantam, gereet staende om te vertrecken, met een eerlijck affscheijt te congratuleeren. Siet de resolutie adij $22 \mathrm{Janu}^{\circ}$.

Op het $5^{\mathrm{e}}$.

Onder deselve (schoon genoomen soo veele coppen geweest hebben) waeren vele onervaren soldaten ende ambachslieden, sommige crancken, sommige gequetsten, eenijge overleden, eenijge met d' $\mathrm{H}^{\mathrm{r}}$ Generael scheep,gegaen, vele swackmoedich geworden door 't vertrecken van de vloote, 't aensien van de groote macht der omliggende vianden ende den langen aenstaenden tijt, die noch voor 't ontset stont te passeeren.

Rijs, olie ende asijn wasser genoech; vleis noch 15 vaten, eenijge met speck; 4 leggers arak, loopende elck 9 à 10 dagen ordinaris, en weijnich soute vis; water mosten meest bij den regen vergaderen, 't gene Godt wt den hemel soude verleent hebben, hebben moeten te vreden houden; cruit hadden 40 vaten, beloopende ontrent 300 scheuten, soo dattet diens aen- 
gaende ten wtersten lijdelijck conde geseit sijn; dan 't woort allerleij nootdruft heeft vele in, daer onder sorteert al de voornamelijckst cloeckmoedijge, ervarene, voorsichtijge overhoofden, oock mede bedrevene ende gewillige soldaten ende borgeren, daer aen het (soo bij den F. $\mathrm{H}^{\mathrm{r}}$ Generael ende Raet geoordeelt wort) de plaetse seer ontbrooken heeft.

Op het $6^{\mathrm{e}}$.

T gewelt van den vijant op 't fort gedaen, is geweest, $1:$ het dagelijx schieten, voornementlijck op de 2 huijsen, continueerende drij weken lange naer 't vertreck van de vloote ende den $E$. $\mathrm{H}^{\mathrm{r}}$ Generael, ende dat in meerder forme als te vooren, als meijnende het alles gewonnen waere; 2 : het verhinderen omme van buijten te fortificeeren ende ter bequaemster tijt het water te putten; oock te onderstaen van de rivier te stoppen, ende op 't laegste waeter te vergeven door seker cruijt oft gruis, dat sincken ende afdrijven lieten, 't welck sommijgen cranck ende onwillige veroorsaect heeft.

D' aproches van de vianden gemaect, sijn 1. en in 't gemein alle hunne baterije selve, liggende buijten de stat, van de welcke alle men met een musquet tot binnen in 't fort conde schieten, als oock verscheijden mael gedaen, somtijts de schiltwacht geraect ende onder anderen 't soontien van schipper Cornelis Francen doot geschooten hebben; 2. de verdubbelinge van Wattings batterije, die de nieuwe bij naeste het vierde part naerder lach dan de eerste; 3 . het aenmaken van d' Eng. baterije, liggende achter 't nieu huijs op de plaetse, daer te vooren hunne logie gelegen hadde; 4 . het nestelen in de afgebranden thooren ende op de hoeckpunte van de stat, beijde liggende op den hoeck ende cant van de rivier, soo na dat met eenen steen soude beworpen worden; 5 . het aenbrengen van 2 grove stucken in de eerste winckelhaeck van de stats walle ontrent een slingerworp van 't fort.

De batterijen (buijten de stat ende haere hooge catte) waeren 4, twee aen Wattings out huijs, d' eene hooger als d' andre, voerende elck 3 stucken geschuts ende 2 bassen; eene achter 't huis Mauritius op de Eng. plaetse, seer sterck ende van d'Eng. oock opgemaect, voerende 8 stucken, ende eene aen de cant ende incoomen van de rivier, hebbende 10 stucken ende twe bassen; bovendien in de stat op de catte 5 stucken ende daer beneden 2 bassen, 3 stucken naer 't fort, d' ander 2 over de 
riviere; noch twe grove stucken in de naeste winkelhaeck van de walle ofte vesten, beloopende in alles te samen 31 stucken ende 6 bassen, behalven 't gene hun noch schadeloos geschooten ende ons onbekent geweest is.

Bressen waeren oock noch gene geschooten; dan ' $t$ was alrede soo verre gebracht, dattet oude huis Nassou d' eene hoeck was wtgevallen ende voorts met schooren ende stutten wert opgehouden, ende ten waere door 't ophouden van't schieten occasie tot selfs af te breken geworden ware, soude in corten selve door 't daveren van ons eijgen schut van boven neder gevallen ende den vijant tot een stormbrugge verstrect hebben. Oock mede was de zuijdhoeck van 't fort tussen de catte ende 't oude huis niet dan met steckagien ende met dunne planxkens van 't secreet beslooten, die nu door 't schieten seer gemartelt ende alsoo tegen eenen aenloop niet bestandich waren; formele stormen en sijnder mede niet gedaen, ende soo bresse geschooten ende 't selve aengebracht waeren geweest, en soude niet hebben wederstaen connen worden, doordien niet eenen, maer verscheijden op eenen tijt soude hebben gedaen, ende ons noodich was alle het volck op d'eerste in tegenweer te stellen, sonder dat malcanderen conden verpoosen ofte ariergaerden, door dien ontrent de 30 liggende crancken, veel seerbeenijge, ende verscheijden hoecken ende plaetsen te bewaeren hadden.

Op het $7^{\mathrm{e}}$.

$T$ Vervolch is dese: naerdat $\mathrm{P}^{\mathrm{r}}$ van den Broeck in hechtenisse gecoomen was, heeft den Coninck dicwils begeert, dat de Catte ende de punt aen 't oost eijnde van 't oude huis mochten afgebrooken ende het geschut te neder geleijt worden, ende naer dat dit alle tijt gerefuseert wiert, begeerde daer naer, dat men dan soude vertrecken ende de plaetse verlaeten, presenterende daer toe een van d'Eng. schepen te vereeren, ende te beschicken. Ende die van 't fort daertoe hem oock niet verstaende, heeft de Coninck beginnen te dreijgen, seggende hem met sijn ende d'Eng. macht dan daer toe soude dwingen. Ende met d'Eng. in compacte getreden sijnde, heeft weder het fort met alles datter inne was in sijne handen geeijst, ende wederomme afgeseijt sijnde, licentieerde d'Eng. nieuwe baterijen tegen ' $t$ fort op te werpen, ende met veel geschut, volck, cruit ende oorloogs amonutie te versorgen en met hun volck ende vaendelen te beplanten. Soo dat daer naer den admirael Thomas Dale het 
fort verscheijden male opgeeijst heeft, somtijts met Engelse brieven door pijlen aen 't fort geschooten, somtijts door gesondene door den jongen van Cornelis Haubraken ende somtijts door de gevangene vrinden over de statsmueren toegeworpen. Ten laesten is 't geschiet door beijde Coningen ende Dale te gelijck met beloften, soo ' $t$ in d'handen van den een oft d' ander wilden overgeven, lijf ende leven soude geschoncken sijn, ende soo niet, haere beijder macht daerop soude thonen ende't selve verleerst hebbende, niet het voorbeloofde perdon ofte 't leven souden houden oft vercrijgen, eijsschend op het alderspoedichste antwoort, eer hunne baterijen souden beginnen te spelen.

Ende alsoo om redenen als volgen niet mogelijcken was tegen hun beijder gewelt te bestaen, ende de missive van 3 Januarijo oordeelde beter waer ter noot aen d' Engelsen dan aen de Javanen over te geven, wert bij de 20 officieren nootdringend raetsaemst geoordeelt ende best gevonden met d'Engelsen in accoort ende handelinge te treden ende te bedingen alsulcke poincten als den tijt soude willen toelaten; ende Jan van Gorcum, capitein, daer toe gecommitteert sijnde, heeft volgens sijne commissie aen d'Engelsen Thomas Dale ende Ruer versocht 't gene volcht: 1. dat naer d'uittreck hij hen soude beschermen voor alle overlast vande Javanen ende andre vianden meer; 2 . dat aen die van 't fort soude verleenen een goet ende bequaem schip om alle des comp volck ende goederen inne te embarqueren, om met hetselfde ende oock hunne perticuliere plundie te mogen vertrecken, waer henen het hun soude geraden duncken; 3 . dattet schip soude tot hunne reijse suffisant ende voorsien sijn met alle nootelijcheijt, ofte dat selve van d'Engelsen naer Amboina vervoert ende hen daernaer 't schip weder gelaten, oft van hen wederom onbeschadicht toegesonden soude worden; 4. dat aen de Hollanders soude verleenen vrije pas omme van gene andre Engelsen gemolesteert te worden, ende wat sulcx als doen meer was.

Doch hadde de capiteijn last ter hooger noot af te staen van des Comps ende onse perticuliere goederen, oock mede van de eerlijcke wttreckinge der soldaten, voor welck versocht, dat met vliegende vaendels etc. wttrecken souden mogen, als wel wetende het de vianden voornamelijck om des Comps middelen te doen ende ons aen de perticuliere niet veel gelegen waere.

Naer verscheijden bijeencomsten (in 't hoff bij den Coninck) 
sijn gheaccordeert sekere pointen, als naerder in de acte daer van den $1^{\mathrm{e}} \mathrm{Febr}$. gemaect ende bij alle 3 pertijen ondergetekent sijnde, daerop ons in desen refererende.

De redenen ende waarom dit alsoo geschiede, sijn deese: 1. het fort was gants swack ende onsterck ten aensien van de macht der omliggenden vianden, als hebbende aen de geheele west ende zuijdsijde, geene flanckeerstucken dan een alleene van de rivier point naer de catte; 't oude huis was gants aen 't vallen ende wert met stutten ende palen overeijnde gehouden; de catte was buijten meest in haeste ende met losse steenen opgelegt, niet genoechsaem om des viants cruisscheuten te verwachten; alle de bolwercken waeren niets als met packen tot borstweringe gemaect oft verhoocht, die dicwils daer ${ }^{\prime}$ heenen geschooten waeren; de punt Hollandia aen de rivier ${ }^{2}$ en was noch niet voltrocken, maer stont het meeste geschut noch beneden op de beddinge, hebbende tot hunne borstweringe niet dan swalpen; de huijsen waeren van binnen niet dan met hunne eijgene mueren versorgt, sonder dat eenijge aerde sonder dan allenelijck een weijnich int nieuwe huis gebracht was ende dienshalven gensins schootvrij en waeren; 2. 't fort was rontsomme met vier sterke baterijen benaut behalven het gewelt wt de stat daerop gedaen wert, hebbende t'samen over de 30 stucken grof geschut, bij de welcke alle Engelsche bosschieters het' gebiet hadden. 300 Engelsen hielden continueelijcken aen lant in de baterije achter 't niewe huis. Den Coninck van Bantam hadde 8000 man den Coninck van Jacatra te hulpe gesonden, ende alle gereetschap tot stormen was veerdich, als sulx bij onse eijgene vrienden gesien ende geavijseert is; 3 . 't Cruit, dat in 't fort was, condebinnen twe dagen, soo het hard aenginge, gemackelijcken verschooten ende geconsumeert werden zijnde ontrent 40 vaten ofte 300 scheuten; doch de $\mathrm{Hr}$. Generael vertreckende, daer af alreede veele verbesicht ende verschooten was. Daer en was oock noch in 4 maenden gans geen assistentie te verwachten oft ontset voorhanden; 4. 't volck was vele sieck liggende ende veele waeren aen de loop, en quade beenen hadden; oock geenen araq met alle meer omme aen 't volck ende d'ingevallene lieden te deelen, noch eenijge versche cost voor de crancken; waeren

1 Lees: "door".

2 De noord westpunt. 
oock sommijge gequetst, sonder dat eenijge chirurgijns hadden daer eenijge hoope op mochten stellen, en is oock niet eene van alle gequetste genesen; daer op oock het gemeijne volck op 't hoochste protesteerden, als blijct bij de informatie ende certificatie daervan op 6 febr. genoomen. Siet alsoo heeft vast het eene ende het ander veroorsaeckt ende genootsaec te doen, dat Godt selve naederhand tot sijne sonderlinge loff, groot profijt van de Comp ${ }^{\text {ie }}$, eer van d' $\mathrm{Hr}$. Generael ende besonder welvaert ende behoudinge onses selves, genadelijck versien ende verhindert heeft; want, genoomen haer gewelt, verwacht hadden soo en souden niet connen bestaen oft lange continueren hebben, maer souden doch ten laetsten alle om lijf ende leven ghecoomen hebben, daerbij d'E. Comp ${ }^{\text {ie }}$ in 't minste genen dienst soude hebben connen geschieden, ende daernaer meer voor onbedachte stouticheijt dan voor cloeckmoedicheijt geoordeelt worden, gelijck in sulcken gevalle vele geschiet.

Op het $8^{\mathrm{e}}$ :

In gevalle het fort den 23 Decemb. 1618 suffisant gekeurt is, sal sulx per avontueren geschiet sijn, ten aensien het generael der vianden, die doen waeren, te weten ten hoochste 5000 Javanen, diens geschut weijnich ende clein ende haer ervaringe in oorloge niet sonders en was, oft doordien apparentelijck niet gedacht en is, d'Engelsen met eene soo groote macht haer te lande tegen 't selve souden verthoonen, oft in regard van de fortificeeringe, die noch dagelijx te doen ende aenstaende nootwendich was. Ofte misschien van degene niet van meninge waeren 't selve te behouden oft beschermen gelijck sulx vele gebeurt. Ten anderen verscheelt estimeren vele van bevinden. Hebben in 't eerst mede soo geoordeelt, dan den tijt heeft ons in opinie doen veranderen; meijnen oock den E. Hr. Generael ende raet niet rondelijck soo van oordeel sijn geweest, doordien in de missive van $3 \mathrm{Janu}^{\circ}$ van accorderen mentie maect, 't welck van een sufficante plaetse te verhaelen, onnoodich is. Is oock bij alle de werelt het fort gehouden als verlooren soude sijn, tensij van de sommijge op d'eene plaetse anders dan op d'andre gesprooken wort, indien de macht van de vianden niet vergroot en meerder geworden was dan de macht der plaetse voor 't fortificeeren, souden den viant noijt goet woort gegeven noch gehoort hebben, maer nu sulx anders is, heeft het minste het meeste moeten wijcken. 
Den handel van 20 Augustij 1618 is mede van den Generael wat wijt loopende gesien, oock hadden de Javanen niet dan haere crissen; 't was bij nachte, alle hoeken ende ingangen waeren hen onbekent en hadden gene geschut van achteren, Gabang het hooft was selfs daerbinnen ende liep mede sijne risijko; onse borgers waeren meerder, een yeder ende was in alles op sijn hoede ende alsoo was 't met hen ende ons een gheheel andre sake. Godt van beyden sij gedanct voor genadige wtcomste.

Op het $9^{e}$ :

Alsoo d'Engelsen de gevangenen, noch de besprokene ostagiers niet mede en brachten, conden die van binnen tot geen wtgaen verstaen, vermoedende datter bedriegerije tussen hen beijden moste schuijlen, ende hoewel dat d'Engelsen daer naer niettemin het fort opeijsten, wilden die van 't fort, vóórdat hunne beloften voltrocken, haer niet te wille sijn; soo dat daerover d'Engelsen met den Coninck in onnenichijt gecoomen sijnde, sij onderstaen hebben haer geschut op 't spoedichst van lant te haelen ende in de schepen te brengen. Ende alsoo hebben d'onse, naer dat d'Engelsen den $6^{\text {en }}$ Febr. schriftelijcken ende bij genomene resolutie rondelijcken weder afgeseijt hadden, hen na gelegentheijt des tijts bij nacht ende dage ${ }^{1}{ }^{1}$ het fortificeeren vervoucht, te meer omdat oock de Javanen met schieten ophielden, ende dit 4 maenden lang continueerende gewent, gebracht in forme diffensijf voor haer beijder gewelt, gelijck het heden ten dage te sien ende in handen van d'E. Hr. Generael Coen overgegeven is.

Op het 10,11 ende $12^{\mathrm{e}}$ :

Het fort af te staen, waeren als doen genootsaect; niet simpelijck om het perijkel, maer om het hoochste prijkel, te weten de berovinge van 't leven te ontgaen soo vele ons doenlijck waer, 't welc tot allen tijden den belegerden in noot te doen, niet qualic affgenoomen is geweest.

Met des $\mathrm{M}^{\mathrm{rs}}$ goet ons rijck te maken (Godt sij getuijge het verre daer af is); de besaeltiens souden 't allen tijden an de Comp ${ }^{\text {ie }}$ gebleven hebben, gelijck daerom bij acte ende hantekeninge yder de sijne hadde ontfangen ende de sommige gene genoomen en hebben; en conden oock niet meer dan 6200 rijaelen met alle het gehele forts volck, hooge ende lege, in

1 Lees: „tot". 
contant uitgevoert worden als bij contract voors. blijct, 't welc niet en conde bedragen, doordien maer wt noodruft op de reijse soude gedient hebben; oock op alsulcke conditie de contanten wtgegeven ende ijders gelt per notitie aenges. waere. Onses wetens en heeft niemant van de opperofficieren ijets wat van de Comp $p^{s}$ goederen genooten, dan allenelijck den gemeijnen man, ende dat in recompense van haeren swaren arbeijt, die gepasseerden tijt gedaen. Boven dit naderhant couragie genoomen hebbende, sijn de diamanten ende contanten weder opgenoomen ende op behoorlijcke plaetse gebercht.

Op het $13^{\mathrm{e}}, 14^{\mathrm{e}}$ ende $15^{\mathrm{e}}$.

Ten eijnde waeromme seker silverwerck aen de Eng. gegeven is, wort geseijt geweest te zijn, omme bij hem in favoor te geraken; ende alsoo door 't gene bij hem alrede als verovert was, ijets wat noch boven het bedongene te vercrijgen, gelijck oock dienshalven noch 2 . stucken geschut ende 2 vaten cruits meer belooft sijn geworden boven 't gene in de artijkel pointen was begrepen ende genomineert is; oock dit geschiet al vooren eer de uure van wttrecken verschenen ende naer het accoort al getekent is geweest.

De diamanten en sijn niet alle gesonden om niet het schip, door d'Eng. prijkel loopende, alle in hunne handen te geraken; sijn oock niet bedriechlijcker wijse achter gehouden ofte versweegen onder protext van alle gesonden te zijn; wort oock het woort "alle" niet in de brief gevonden, als in het interrogatorium is gedaen, want luijt den brief aldus: "bij deesen gaen wt het fort een 12 besaliens diamanten etc." Ende dit is mede alsoo gedaen om oft den Tijger van de Eng. beseijlt ende verovert hadde geworden, sij wt den brieff niet en souden verstaen, daer noch eenijge in 't fort waeren gebleven, hoe wel anders wel kennisse hadden eenijge met Zeylon wt Succadana waren gecoomen. Dit was oock den schipper selver bekent, die persent geweest, als dit alsoo besloten is.

Op het $16^{\mathrm{e}}$.

De besaenkens sijn geopent om des te bequamer gebercht ende voor der vianden visitatie verduijstert te connen worden; anders oock om voor alle werelt te bethoonen, niemant aller hen ' daerin sochte, maer sulx voor het gemeijne beste wilde preserveren.

1 D. i. zich zelven [te bevoordeelen]. 
Op het $17^{\mathrm{e}}, 18$, ende $19^{\mathrm{e}}$.

Sal soo verhoope van redenen bij andre persoonen bequamelijcker ende beter geantwoort worden, als bij den onderges., als de saecke naerder bekent sijnde.

Actum in 't fort Jacatra den $11^{\text {en }}$ Junij 1619 w.g. Adriaen Jacobsen Hulsebos $11 / 6 \mathrm{a}^{\circ} 1619$ M. V. 


\section{Bijlage VI a.}

Resolutien van

Generaal en Raden

1613-1620.

Kol. archief.
Maandag den 13 Februari $a^{0} 1617$ in Jacatra.

Alzo per prauw van Bantam door $S^{r}$ Buijsero verstaan hebbe, dat aldaar een Fransch schip Marguerite genaamt, in comp. van t schip de Montmorenci in Maijo laatstleden van Diepen gezijld, gearriveert was, waarop diverse Nederlanders zijn, so is goedgevonden dat men aan Buijsero zal advijseeren, dat zal tragten volgens de placaten van de Hoog Mogende Heeren Staten Generaal ende ordres van de Heeren Majores deselve Nederlanders in apprehentie te krijgen, 't $z i j$ door de een of andere middel, dog eerst met soetighijd 'tselve te onderstaan, en zo niet willende gelukken met alsulken middel, 't zij met geweld off anders als den tijd zal openbaren ende mede brengen, also de Comp. aan 't versekeren ende 't ligten van voorz. Nederlanders veel gelegen is. w. o. J. P. Coen, S. D. Groenendijk, Pr. de Carpentier, Jacob Breetveld.

\section{Bijlage VI b.}

\section{Vrijdag adij 17 Februarij $a^{0} 1617$. In Bantam.}

- Also alhier [op] de 2 scheepen te Diepe in Vrankrijk toegerust en alhier gearriveert diversche Nederlanders zijn varende, onder de jurisdictie van de Hoog Mog. Heeren Staten Generaal horende, waarvan alhier in de loge zijn gearresteerd:

Pieter Gerritsz van A'dam, opperstuurman, voor desen in Indien geweest met het schip de Maagt van Dort onder de vlagge van admiraal Heemskerk, daarna onder de vlagge van den admiraal Màttelieff met het schip genaamt Orange.

Melis Reijersz Lams van Hoorn, oppercoopman, voor desen in Indien geweest onder de vlaggen van den admiraal Verhaagen met het schip Groot Hoorn.

enz.

alle te samen gevaaren hebbende op 't grote schip, zijnde admirael, genaamt Montmorency, dewelke voor ons gecompareert 
zijnde en hun voorgehouden hebbende 't placaat ende verbod der Hoog Mog. Heeren Staten Generaal enz.

Daarop eendragtelijk hebben verklaart ende gezegd nooijt geweten te hebben, doen zij aangenomen wierden, herwaards zoude komen, nog ook ooijt enige articulbrieff hun en is voorgelesen ofte doen beëdigen, maar wel dat op een vreemde rijse ginge, waarvan elk het zijne gevoelde tot er tijd aan Cabo de Bona Esperance quamen, als wanneer hun per force ende met geweld hebben gedwongen herwaards te brengen; versoekende daaromme onse onderstand om aan hunne goederen en maandgelden te mogen geraken, also gaarne en liever de Comp. als vreemden wilden dienen, want sijden tegen haar dank door bedwang hier zijn gekomen. Actum ut supra. w. o. J. P. Coen, Steven Doensen van Groenendijk, C. Buijsero, A. v. Bree, T. G. van Ravenstijn, Pieter Jansen, Thijs Cornelissen Vleeshouwer, Secretaris.

\section{Bijlage VII.}

Rijksarchief.

Register van de brieven en papieren

overgecomen in den jare 1620 .

Boek II, fol. 132 .

Alsoo Melis Remmets Lants van Hooren, wtgevaeren voor oppercoopman van Diepe in Vranckrijck met de schepen Montmorenci ende Margriette, ende op sijn aencompste alhier tot Bantam neffens alle de Nederlanders, die daermede gecomen waeren, door expresse placaten vàn de Heeren Staten ende ordre van de Heeren Meesters gelicht van de schepen ende in dienste van de Generale Comp $p^{\text {ie }}$ aengenomen op ten $4^{\text {en }}$ Maert $a^{\circ} 1617$, te weten de voors. Lanst voor ondercoopman à 40 gld. ter maent, vermits hij ende alle d'andre alsdoen verclaerden, dat se op haer wtvaeren niet en wisten, dat se naer Indien souden vaeren, maer op de reijse sijnde tegens haer wille ende dancke van de Francen daertoe gedwongen werden; ende alsoo den selven Lanst met 't schip den Gouden Leeuw als nu van de custe van Cormandel alhier is gecomen, ende ons nu met de jonckste schepen van de Heeren Meesters seeckre interrogatorien ter handen gecomen sijn, in dato 14 Maert $\mathrm{a}^{0} 1615$ tot Hoorn daerbij claerlijcken blijct, dat den voors. Lanst beneffens noch eenen Sijmon Jorisen 
Looff (die wij alhier niet en hebben vernoomen) sijn aengenoomen om alhier in Indien te vaeren, ende van de $\mathrm{H}^{r}$ Officier ende Magistraat der steede Hoorn gewaerschout sijn van de voors reijse te desisteren, daerop hij ende den voorn. Sijmon Jorisz Looff oock in handen van de officier ende magistraet voornt. met eede belooft hebben, in dienst van de voors. Franse oft andre vreemd natie nae Indien niet te vaeren. Des niettegenstaende heeft hem evenwel verstout tegens sijne gedaene eet, eere ende belofte met de voors. Franse schepen herwaerts aen te comen ende op sijn aencompste tot Bantam voor den $\mathrm{H}^{\mathrm{r}}$ President ende den Raet te verclaren, dat hij niet en wiste dat naer Indien varen soude. Soo is 't dat den $\mathrm{H}^{\mathrm{r}}$ President ende de presente Rade, prefererende de gratie in plaetse van rigeur van justitie, nochtans willende recht doen om d'ordre van de Ed. Mog. Heeren Staten Generael ende de Heeren Mrs. te volgen, den voors. Melis Remmets Lants ten respecte voors. ende exempel van andre, gecondemneert hebben ende condemneren hem mits desen, dat hij van de voors. tijt van sijn aenneminge aff tot nu toe geen gagie genieten ende voorts sonder gagie naer ' $t$ vaderlant vaeren sal. Aldus gedaen adi 21 November 1618 . In Jacatra (was onderteeckent) J. P. Coen, Pr. de Carpentier, Samuel Kint, Willem Jansen, Pieter Dirxen, Pr. v. Broeck, Jaques le Febre, Pieter van Raij, Thijs Corn. Vleijshouwer, Secrs.

Gecollationeert jegens d'originele ende daer mede bevonden te accorderen In 't fort Jacatra, adj 7 Octob. $a^{\circ} 1619$.

(w.g.) Thijs Corn. Vleijshouwer, Secrs. 


\section{Bijlage VIII.}

Rijksarchief.

Register van de brieven en papieren

overgecomen in den jare 1620.

Boek I, fol. 356 .

Op heden den 10 Junij $\mathrm{a}^{\circ} 1619$ is gecompereert Melis Remmesz Lants oudt ontrent 44 jaeren, ondercoopman geweest in 't fort Jacatra, den welcken door last van d'H. Generael geëxamineert zijnde, op tegenstaende poincten heeft verclaert, geschiet te sijn als volcht:

1.

Antwoort hier aff geen kennisse heeft.
Interrogatorium omme daer op te hooren den raet van 't fort Jacatra soo elck besonder als alle in 't generael als namentlijck.
1.

Off haer niet kennelijken is, hoe d' $\mathrm{Hr}$ Generael Coen met eenparige stemme en goedvindingh van den raet den oorloch tot Jacatra tot versekeringh van 't fort ende des Compes volck en goederen aengenomen heeft, omme die tegens alle gewelt van vijanden tot den uijttersten uijt te voeren, dewijle anders door verscheijden baterijen, die dagelijcx op diverse plaetsen onder een vrientlijck gelaet dicht aen ende ontrent ons fort gemaeckt wierden, met gewelt gedwongen soude hebben geworden.

2.

Seijt dat doen ter tijt Waeromme sijlieden dan cort naer sieckelijck is geweest ende 't vertreck van den $\mathrm{Hr}$ Generael Coen derhalven niet en weet aen den Coninck van Jacatra vijff 
waeromme het gelt gege- duijsent realen van $8^{\text {en }}$ in spetie ende ven is.

duijsent in cleeden gegeven hebben, voor soo een valsche vreede, daer vooren den oorloch cort te vooren bij den raet geprefereert is geweest.

3.

Refereert hem op'tvoorgaende poinct.

4.

Antwoort: dat in 't resolveren niet is geroepen, noch insulcken raet gebruijct.
3.

Waeromme soo grooten somme gelts ende goederen van ses duijsent realen aen trouloose mooren op een simpel accoort van vrede gegeven is, sonder eenighe versekeringe daer tegens te hebben, dewijle alle de werrelt kennelijck is, dat bij den Coninck van Jacatra ende sijne adherenten in aller manieren getracht is gewest onse huijsen aff te loopen.

4.

Hoe sijlieden goet hebben connen vinden, dat Pieter van den Broeck, commandeur van 't fort twee dagen na dat voors. beveijnsde vrede gemaeckt was met een goede swijte volck bij den Coninck van Jacatra souden gaen vergasten, dewijle haer kennelijcken is en oock eenighe selfs hebben helpen resolveren, dat men geentsints goetvont, niet tegenstaende d' uijtmuntende groote instantie bij den Coninck van Jacatra gedaen, dat den $\mathrm{H}^{r}$ Generael Coen bij hem in 't Chinees quartier soude gaen en dat noch eer den oorloch aengevangen waer, off eenich verschil geresen sij; laeten staen, hoe veel te min voors. Coninck behoorden te vertrouwen, nadat den formelen oorloghe gevoert hadde ende alle sijn valsche aenslagen ontdeckt ende gemist waeren.

Dl. 73 . 
5.

Antwoort: door sijn siecte nieuwers aft te weten.

6.

Seijt, dat d' Engelsen een baterije achter haer oude huijs gemaect hebben, doch daerwt geen gewelt gedaen.

\section{7.}

Verclaert doordien dat DircqJemming ende daerna den CommandeurPieter van den Broeck gebonden op de muijr van de stadt quamen, roepende dat men het fort in de handen van de Javanen off Engelssen souden geven, alsmede door seeckre missive door d'Engelssen geschreven, die 't fort op eijschte ende daer wt souden gaen, behoudende het leven, ende soo het niet gewillich wilden op geven, dat se souden stormen ende daerna niemant verschoonen.
5.

Off de Generael Coen op sijn vertreck het fort Jacatra niet heeft versien gelaeten met 250 werbaere coppen, 41 stucken groff geschut, daer toe over de 40 vaeten cruijt met vijvres ende alderleij nootlijcheijt versien voor den tijt van ontrent 8 maanden.

6.

Wat gewelt datter naer 't vertreck van den Generael Coen op 't fort gedaen is, wat aproces de vijanden gemaeckt hebben, hoeveel baterijen ende hoe veel geschut teghen haer geplant is geweest, hoeveel schoten den vijant dagelijcx, wat bresse de vijanden met scheuten gemaeckt hebben, ende wat stormen datter gedaen sijn.

7.

Hoe ende in wat manieren sij lieden dan aen 't parlementeren met de vijanden geraeckt sijn, wat accoort met d'Engelsen ende Javanen gemaeckt hebben, ende op wat conditie de plaetse overgeven souden, ende waeromme. 
8.

Antwoort hier op, dat het fort in 't eerste niet bequaem was om het gewelt van de Engelschen ende Javanen weder te staen.

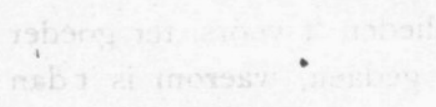

9.

Antwoort: de plaetse gehouden te sijn, door dien dat interim in 't parlementen waeren, de plaetse met alle neersticheijt versterckt is.
8.

Waeromme sij lieden met meerder macht niet houden costen een geslooten fort, 't welck lange te vooren als namentlijcken 23. December 1618 bij den raet ende bij u. 1. selffs suffisant gekent wierdt omme tegen alle gewelt gehouden ende gedefendeert te worden, als par resolutie blijct teghen de selvige vijanden, die niet hadden derven onderstaen ' $t$ begin van 't werck, doenne noch geen teecken van 't fort ende sach, te verhinderen; jae die betoont hadden selven niet machtich te kennen omme aff te loopen de twee simpele huijsen, gelijck sijlieden den $20^{\text {en }}$ Augusto 1618 geerne gedaen hadden, sijnde alsdaen met meer dan 500 mannen des nachts binnen de huijsen geweest, daer toe noch eenighe duijsende egelijck een ider weet tot haer hulpe rontsomme de huijsen veerdich hadden.'t Is waer datter doen [geen] geschut tegen de huijsen geplant was, maer van onse seijden wasser oock geen veerdich ende geen ander tegenweer dan omtrent 45 soldaten in de wapenen, soodat naderhandt allengskens 't eene gewelt tegen ' $t$ ander gewassen is, ende ons voordeel naderhandt veel grooter dan in 't eerste was.

9.

Was de plaetse niet suffisant endegenochsaem in sijne opmeten beslooten om tegen soo groote gewelt gehouden te worden, als was de macht daer mede ghijlieden gedrijcht wiert; endegebrack U.1. iets, hoe ende waermede is dan de plaetse tot nu toe gehouden. 
10.

Antwoort: geresolveert is geweest de plaetse over te geven, maer dat hij geen goederen altoos heeft genooten.

11.

Seijt, bij geen verdeijlinge geweest, noch geen goet als boven gecregen heeft.

12.
Antwoort, dat hem $50 \mathrm{R}$.
gegeven waeren, die hij
daerna weder gerestitueert
heeft.

(2)

13.

Antwoort, dat niet en weet, hoe veel off wat gelt off goet aen d'Engelsen gegeven is.
10.

Sijt ghij niet geresolveert geweest de plaetse over te geven om perijkel te ontgaen, ende om U met de Meesters goederen te verrijken.

11.

Waeromme hebt ghijlieden onder het volck ende onder den anderen gedeijlt veele van des Comps goederen ende contanten, oock die van den $\mathrm{Hr}$. Generael Coen ende andere partijculieren, sonder reckening off notitie daervan te houden; wie d'ordre ofte last gegeven heeft sulcx te doen, tot wat eijnde, off is sulcx sonder last gedaen; waeromme isser gheen behoorlijcke ondersoeck gedaen ende d'overtreders als dieven ende voleurs gestraft, ende waer is het oijt een gebruick geweest als men genootsaeckt wordt een plaetse over te geven, dat de hoofden dan selfs kisten ende casten doen off laeten opbreken ende de goederen pilleren.

12.

Hebt ghijlieden 't voors. ter goeder meeninghe gedaen; waerom is ' $t$ dan dat naderhandt, weder couragie geschept hebbende, alle de gedeijlde goederen niet weder opgenomen ende elck op sijn behoorlijcke plaetse geberght hebt.

13.

Wat gelt, silver ende silverwerck sijlieden aen particulieren d'Engelsen gegeven hebben, waeromme ende tot wat eijnde sulcx gedaen is. 
14.

Seijt, in dese pitsiaring niet en is geweest, noch geen brieven geteeckent.

15.

Verclaert hiervan geen kennisse te hebben.

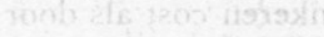

14.

Hoe met het jacht de Tijgher, neftens R. 69.0. Japons silver, na Amboijne gesonden is een pacxken diamanten met advijse daer beneffens, dat men sont de diamanten met het jacht Ceijlon van Suckedana gecomen, daer men ter contrarie niet dan de minste helft en sont ende de meest achter gehouden heeft, wesende over de drie hondert caratten.

15.

Wat is de meeninghe geweest dat men soo grooten pertije dijamanten bedrijechlijker wijs achter gehouden heeft; is het geweest om de geheele pertije niet te risikeeren, waeromme heeft men dan d'eene helft gehouden ende na Amboijna geschreven dat men alles sont.

16.

16.

Antwoort als vooren hier aff niet te weten.

17.

Weet hier mede niet aff. Broeck, gevangen sijnde, drie besaeltjens dijamanten gesonden sijn.

18.

Weet hier niet anders aff, dan dat 's nachts in de combuijs gecomen is ende gesien heeft, dat Mibaijs eenige boecken verbrande, doch wat boecken en pampieren het waren, heeft niet affgevraecht,
18.

Bij den Heer Generael Coene is geordineert geweest, soo men in uijttersten noot geraeckten ende genootsaeck wiert de plaetse over te geven, dat men dan sijne pampiere verbranden soude; maer dewijle de noot noijt gedrongen heeft, waeromme sulcx te vooren gedaen is, 
ende dat in sulker voughen, datter niet verschoont en is van al ' $t$ gene alle de werrelt wel hadde mogen sien; jae selffs niet de generael boecken, facturen van coopmanschappen, facturen van de voorsz diamanten, de drijevoudighe commissen van d'Hr. Generael Coen ende ontallijke ander missiven ende pampieren meer.

19.

Weet hier op niets anders te antwoorden.
19.

Waeromme de punct leggende aen 't oost eijnde van 't oude huijs niet geleijt en is na de eijsch van een viercant fort in sulcker voeghen, dat die op de cat flankeren cost als door de Generael Coen te vooren geprojecteert ende met paelkens aftgetekent is geweest, gelijck bij mester Jan van den Broeck u. 1. aengeseijt [ende] aengewesen is.

Aldus gedaen in presentie van $\mathrm{H}^{\mathrm{r}}$ Andries Sourij ende Jacq. le Fevre door d'Hr. Generael daertoe gecommitteert in 't schip den Gouden Leeuw. Actum ut supra. 


\section{Bijlage IX.}

Rijksarchief.

Register van de brieven en papieren overgecomen in den jare 1620.

Boek I, fol. 234.

Vrijdach den $25^{\mathrm{e}}$ Januaris $\mathrm{a}^{\circ} 1619$.

Alsoo [Godt beteert] dagelijkckx meer en meer door onse vijanden benaudt ende van alle canten met stercke baterije, wel versien met geschut, beset worden, is hoochnoodich onse swacke muren, puncten (tot defentie van onser vijanden macht) te verstercken ende met aerde te vullen, waertoe (niettegenstaende geheel swack sijn) veel volcx van noode hebben, soo dat (alsoo onse soldaten met sware wachten belast zijn) bijna alle den arbeijt door onse swarten moet te wegen gebracht werden, d'welck alreede langhe geduert heeft ende naer alle apparentie maer schijnt te beginnen, ende sijlieden voor haeren bitteren arbeijts versochten nae alle slavernije liber ende in vrijheijt beneffens d'andre negros gestelt te mogen werden; soo is 't, dat den presente Raet, gelet hebbende op't voorn. versoeck ende den ijverige vliet, ja bijnaer-onmenschelijcke arbeijts tot noch toe bij haer gedaen ende noch langhe moeten continueren (waerinne sij beloven haer gewillich ende neerstich te laeten gebruijcken, lijf ende leven tot behaudenisse van 't fort nevens ons te wagen), hun hebben belooft ende toegeseijt (soo Godt gelieven) 't fort in essie ${ }^{1}$ ende behouden blijft, ter compste van den $\mathrm{E}$. $\mathrm{H}^{\mathrm{r}}$ Generael Jan Pietersen Coen, hunne versochte vrijheijt ende liberteijt te procureren ende sekerlijck te bevoorderen. Aldus gedaen ende gearresteert in 't fort Jaccatra, dattum als boven.

$$
\begin{aligned}
& \text { (w.g.) Pieter van Raeij. } \\
& \text { Jan van Gorckum. } \\
& \text { A. J. Hulsebos. } \\
& \text { Evert Harmansen. }
\end{aligned}
$$

I In wezen. 


\section{Bijlage $\mathbf{X}$.}

Als vorige bijlage.

fol. 102 .

Alsoo Pieter van Raij commandeur geweest int fort. Jacatra naer de gevanckenisse van Pieter van den Broecke, Jan Jansen van Gorcum, cappiteyn, Adriaen Jacobsz Hulsebos als raet ende Evert Harmensen, coopman, hen soo verre verloopen ende soo slechtelijck gehandelt hebben als namentlijck ende voor eerst, dat sij op den $19^{\text {en }}$ Januari 1619 aen de Coninck van Jacatra seer lichtvaerdelijcken, op het accoort ende stilstant van wapenen metten voorn. Coninck gemaeckt, hebben vereert vijff duijsent realen van $8^{\text {en }}$ in contant ende duijsent realen in custcleeden; daernaer op ten $22^{\mathrm{en}} \mathrm{d}^{\mathrm{o}}$ int resolveren ende senden van haeren commandeur Pieter van den Broecke bij den Coninck met een schenckagie, die welcke als doen int hoff comende datelijck met alle degene, die bij hem waeren, vast gehouden wierden. Ten derden ende voornamentlijck, dat sij haer eet ende eere vergetende, op ten eersten $\mathrm{Feb}^{\text {rij }}$ daeraen sonder eenige wtterste noot, storm oft schoot verwacht te hebben dan alleenlijck op de ijdele dreijgementen van de Engelse ende Javanen, die haer met diversche batterijen ende bolwercken omcingelt hadden, wt enckele vrese, met d'Engelse ende Javanen in onderhandelinghe sijn getreden, geresolveert ende volcomentlijck geaccordeert hebben het fort ende alles in handen vande Engelsen ende den Coninck van Jacatra over te geven op soo slechten conditie, dat apparent was, soo 't voort gegaan' hadde, sijlieden ende alle het volck vermoort oft door meserie vergaen souden hebben, als per accoort door haer geteeckent blijct, mits dat sij met haere goederen ende 6200 realen in spetie daer wt soude gaen; ende alsoo sij gereet waeren om met alle man daer wt te gaen, verwachtende alleenlijck naer den Commandeur Pieter van den Broecke ende d'andre persoonen bij den Coninck van Jacatra gevangen, alsmede naer de boots van d'Engelsen om daerin te treden, is ten vierden maele (alle andere bysondre ongeregeltheden, uytdeelinge van gelt ende goederen onder 't volck, overspel ende ongeschictheden overslaende) soo groote faulte begaen, dat niet sonder suspitie en is, eenighe met soo lichtvaerdich overgevinge van 't fort haer selven hebben soecken 
te verrijcken, oft dat anders te lichtvaerdiger tot d'overgevinge geresolveert sij door de beroovinge ende plunderinghe van goederen; die bij vele gedaen is, alsoo een ider veele van des Comps goederen ende comptanten in haere kisten gebercht, als oock de kisten van perticuliere persoonen, als namentlijck die van, d'Hr Generael selffs, de kiste van Jacques le Fevre, Pieter Dircxen, oppercoopman, ende Thijs Cornelissen Vleijshouwer, secretaris, die absent ende met sijn Ed. vertrocken waeren, sonder respect open geslooten, open gebroocken ende de goederen daerwt genoomen hebben, een yder soo veel als hij begeerde ende bergen conde, ende alle de pampieren vande $\mathrm{Hr}$ Generael, als mede de drievoudighe commissie van de Hoochmogende Heeren Staten sijn Princelijcke Excellentie ende de Heeren Maijoors verbrant; hebbende oock groote schenckagien aende Engelsen ende Javanen gedaen om soo sij seggen faveur bij haer te genieten, ende de besaeltjens diamanten opengebroocken ende onder haer verdeelt; doch daernaer siende, dat d'Engelsen volgens haer beloften de gevangenen, bij den Coninck van Jacatra sijnde, in haer handen niet en leverden, maer dat sij naer Bantam vervoert wierden; vresende daerover datter wederom eenich bedroch oft verraderije onder schuijlde ende dat d'Engelsen van meer andere poincten, int contract belooft, in gebreecke souden mogen blijven, als oock dat d'Engelsen haer voor de Javanen niet souden connen bevrijden, hebben sijluijden geweijgert wt het fort te gaen ende d'overleveringhe aen d'Engelsen te doen; begeerende eerst dat de gevangenen ende de genoemde ostagiers binnen 't fort volgens accoort gelevert werden ende comen souden, 't welck door die van Bantam verhindert sijnde, alsoo d'onse tot Bantam gevangen wesende door inductie van den Pangeran aldaer denselven seer goede hoope gaven, het fort niet aen d'Engelsen, noch den Coninck van Jacatra, maer in sijnne handen te leveren ende doen overgeven. D'Engelsen hierdoor met die van Bantam in questie geraeckende, hebben haer geschut begost te scheepen, ende eenighe stucken gescheept sijnde, heeft d'voors. raet op den $6^{\text {en }}$ derselver maent Febuarij geresolveert, d'overleveringhe van 't fort aen de Engelsen ende de Coninck van Jacatra schriftelijck te weijgeren, gelijck als doen geschiede met de gevangen van Bantham, accorderende, dat het beter waere het fort aen den Coninck van Bantam, die sijn belofte coste houden soo sij seyden, over te leveren, dan aen de 
Engelsen; doch alsoo 't gemeene volck hun hier tegen stelden, resolveerden 's anderen daechs den $7^{\text {en }}$ Febr. wederomme occasie te soecken om d'overleveringe aen d'Engelsen te doen; maer d'Engelsen, ter bestemder tijt niet comparerende, hebben haer naemaels weder affgeseijt ende den $9^{\text {en }}$ Februarij volcommentlijck geresolveert, het voors. fort op seeckre conditien bij heur geraemt aen den Pangoran van Bantam over te geven, welcke conditien denselven Pangoran voorgeleijt sijnde, heeft alles geadvoijeert, wtgesondert dat van d'Engelsen geen vrijpas voor d'onse gesonden heeft. Den Raet, door vreese van d'Engelsen op 't selvige pas persisterende ende den Pangoran willende geen pas van d'Engelsen versoecken, is ondertusschen veel tijt verloopen, sulcx dat den loop van saecken d'voorn. raet heeft gedwongen haer dagelijcx meer ende meer te verstercken ende binnen 't fort te blijven, waer over het fort, volck, veel van des Comp ${ }^{\text {ies }}$ gelt, goederen ende alle dependentien van dien, niet door haere wijsheijt, maer door sonderlinghe genade ende schickinghe Godes, die daervan oock ten hoochsten gedanct sij, behouden is. Den Heer Gouvérneur Generael ende de presente Raden van meninge sijnde, dit ten exempel van andre niet ongestraft te laten passeren, opdat sulcx niet meer come te gebeuren, te meer vermits de voors. persoonen haer faulte niet en willen bekennen, maer even opstinaet ende hertneckich persisteren, dat door wterste noot gedrongen worde ende niet mogelijck en was, dat ' $t$ fort in die tijt 't gewelt van de' Engelsen ende Javanen beijde te gelijck conde tegen staen, even off haer schuldige plicht voldaen hadden ende niet gehouden waeren het fort tot d'uijtterste noot te houden, maer als off van de Generael expresse last gehadt hadden het fort, als weijnich daeraen gelegen sijnde, met accoort aen de vijanden over te geven, niettegenstaende in haere confessie selffs bekennen, datter van de vijant geen approche, noch storm gedaen, ja niet eenen schoot, naer dat d'eerste vrede gemaeckt was, van d'Engelsen noch Javanen op haer geschooten is; als off haer tijt gebroocken soude hebben om 't fort over te geven, soo sij een schoot verwacht hadden, daer nochtans de plaetse bequaem was, geen vivres gebraecken, cruijt ende volck genoch hadden om eenige stormen aff te slaen; gants vergeten hebbende, dat de plaetse suffisant gekent was, om redelijcker wijs versien sijnde, groot gewelt te connen wederstaen, ende dat sijlieden selffs het gewelt van d'Engelsen ende Javaenen met 
gewelt ende goede coeragie hadden helpen wederstaen van 23 December 1618 tot den $14 \mathrm{Janu}^{\circ} 1619$, dat d'eerste furie van oorloghe geduyrt heeft, ende de Coninck van Jacatra wetende met gewelt niet te voorderen, de vrede selffs weder versochte. Hebben de voorn. Pieter van Ray, commandeur, die nu onlancx overleden is, Jan Jansen van Gorcum, capiteyn, Adriaen Jacobsen Hulsebos als raet ende Evert Hermansen ten respecte voors. gedeporteert, soo sij hen deporteren mits dese van haere officien, haer onbequaem verclaren om meer in diergelijcke vergaderinge gebruijct te worden, ende dat een yder van hen weder sal treden in sijn bedieninge daer vooren uijtgevaren is; ende alhoewel den luytenant Abraham Strijcker, den vaendrich Hendrick Hermansen ende alle d'andre persoonen, die de resolutie nopende t'overleveren van fort geteeckent hebben, mede miriteren gedeporteert ende gemulcteert ${ }^{1}$ te werden als naementlijck Mr. Jan van den Broecke, schoolmeester, Joseph Jansen de Natelaer, Melis Remmisz Lanst, Jan van der Dussen, ondercooplieden, Jan de Brasser, Jan Mibaijse, Samuel Merchijs, Cornelis Jacobsen Gael, Anthonie Meeusen, assistenten, Juriaen Jansen, constapel maijor, Dirck Reijniersz, Willem Hendricksz Jongbloet, Elias Rippon ende Andries Fransen, sargeanten; soo geschiet nochtans d'voors. luytenant Abraham Strijcker, ten respecte van sijnne siecte daermede doen ter tijt beladen was, gratie, als mede aen den vaendrich ende alle d'andre daerenvolgende persoonen; condemnerende daerenboven de voors. vier principaele hooffden als Pieter van Raij, commandeur, Jan Jansen van Gorcum, cap ${ }^{n}$, Adriaen Jacobsen Hulsebos als raet, Evert Harmansen, coopman, ende alle degene, daer bij alreede eenige van des Comp ${ }^{\text {es }}$ ende particuliere goederen bevonden sijn, die overtuijcht soude mogen werden eenige goederen genooten te hebben oft naemaels noch yets bij haer mochte comen te vinden, te voldoen ende te betaelen allen 't gene van des Comps ende andre perticuliere goederen gerooft, geplundert, aen d'Engelsen gegeven oft andersints noch bevonden sal worden te gebreecken, wtgesondert ' $t$ gene in de bolwercken als andersints tot versterckinge van fort geconsumeert sijn. Ende dat elcx pro rato voor soo veel als naer desen bij den $\mathrm{Hr}$. Generael ende den Raet tot naerder bevindinghe van saecken verclaert sal worden, te weten voor soo veel haer jegenwoordighe goederen

1 Muleter = condamner à l'amende, tot geldboete veroordeelen. 
ende maentgelden totten $27^{\mathrm{en}} \mathrm{Feb}^{\mathrm{rij}} 1619$ (als wanneer ten deele wederom tot kennisse gecomen ende tot haere devoiren gekeert sijn) mogen strecken, van welke tijt aff sij weder haer gage sullen genieten. Aldus gedaen ende gesentieert in't fort Jacatra; adj 9 Julio $\mathrm{a}^{\circ} 1619$ - was onderteeckent J. P. Coen, Laurens Reael, Steven van der Hagen, $\mathrm{P}^{\mathrm{r}}$. de Carpentier, Willem Jansen, Andries Sourij, $\mathrm{F}^{\circ}$. van Meer, Pieter Dircxz, Thijs Cornelisz Vleijshouwer, secrs. 


\section{Bijlage XI.}

Als vorige bijlage.

fol. 43 dorso.

Alzoo bij sententie op den $9^{\text {en }}$ Julio passado gecondemneert sijn de principale hooffden van 't fort Jaccatra, namentlijck Pieter van Raij, commandeur, Jan Jansen van Gorcum, cappeteijn, Adriaen Jacobsen Hulsebos als raedt ende Evert Harmansen, coopman, mitsgaders alle degeene, daer bij al reede enige van des Comps ende andre perticuliere goederen bevonden sijn, die overtuijcht souden mogen werden eenige goederen genooten te hebben offt naermaals noch iets mochten comen te vinden, te voldoen ende te betaelen allent gene van des Comps ende andre perticulieren goederen gerooft, geplundert, aen d'Engelsen gegeven oft andersints noch bevonden sal worden te gebreecken, wtt gesondert 't geene in de bolwercken als andersints tot versterckinge van 't fort geconsumeert $z \mathrm{ij}$, en dat elck pro rato voor soo veel als naer desen bij den Heer Generael en den raedt tot naerder bevindinge van saecken verclaert sal werden, 't welcke voor soo veel haer jegenwoordige goederen ende maentgelden totten $27^{\text {en }}$ Febr. 1619, als wanneer ten deele wederom tot kennisse gecomen ende tot hare devoiren gekeert sijn, mogen strecken, van welcke tijt aff sij weder haer gagie sullen genieten, alles blijckende bij de voors. sententie, ende alsoo men tot noch toe geen naerder bevindinge van saecken heeft connen becomen, vermits de voors. principale hooffden ende alle anderen, die de goederen hebben gerooft ende daer, bij alreeden soo van des Comps als perticuliere goederen gevonden sijn, namentlijck Jan van der Dussen ende Hendrick Lambertsen, ondercooplieden, Jan Anthonisse Brasser, Jan Mibaijse, Cornelis Jacobsen Gael, Samel Marcijs, Cornelis Arentsen, assistenten, en Witte Cornelisen, taffelknecht, even opstinaet ende hertneckich blijven om aenwijsinge te doen, soo wert bij den Ed. Heer Gouverneur Generael ende de presente raden voor naerder verclaeringe wtgesproocken, dat de gagie ende goederen van de voors. persoonen totten $27^{\mathrm{e}} \mathrm{Febr}$. passądo verdient, onder de Heeren Meesters in areste sullen blijven, soo lange tot datse alsulcken informatie van der saecken sullen geven, dat de Generale Comp $\mathrm{p}^{\text {ie }}$ ende de perticuliere 't hare becomen mogen ende de saecke behoorlijck aff gedaen can worden. 
Item alsoo eenige perticuliere persoonen, die met den Heer Generael wt het fort 't scheep gegaen waeren om d'Engelse vloote te gemoet te gaen, haere kisten opengeslooten, opengebroocken ende de goederen daer wt genomen sijn, conforme haere schriftelijcke specificatie tot dien eijnde overgegaen ${ }^{1}$, bedragende in alles $1421 \frac{1}{2}$ reallen van achten.

Namentlijck:

De goederen door d' $\mathrm{H}^{\mathrm{r}}$ Generael Coen verlooren R. $554 \frac{1}{2}$

die van Jacques Lefevre, oppercoopman . . . \258.-

van Pieter Dircx, oppercoopman . . . . . , 269.-

van Thijs Cornelisen Vleijshouwer, secretaris . , 157.-

van Hendrick de Haen, medicus . . . . . . , 168.-

van Jan de Clercq, tamboer . . . . . . ., $20 .-$

\section{R. $1421 . \frac{1}{2}$}

Is goet gevonden, dat henlieden wt de middelen van de Comp ${ }^{\text {le }}$ alhier sal werden betaelt van de gagie ende 't procedido van de goederen der voors. persoonen, die bij haer in arest blijven :

Te weten:

D'Heer Generael . . . . . . . . . . . R. 300.-

Jacques Le Fevre. . . . . . . . . . . , 150.-

Pieter Dircxsen . . . . . . . . . . . , 150.-

Thijs Cornelisz Vleijshouwer . . . . . . . ” 90.-

Hendrick de Haen . . . . . . . . . . , 80.-

Jan de Clerck, tamboer . . . . . $\frac{20 .-}{\text { R. } 790}$

Op conditie, soo op naerder informatie van saecken anders bevonden wordt te behooren, dat dese persoonen gehouden sullen wesen, ider 't gene ontfangen heeft weder goet te doen.

Actum in 't fort Jacatra adij 5 Octob. $a^{\circ} 1619$ etc.

w. g. Jan Pieterse Coen

Steven van der Hagen

Frederick Houtman

Pieter de Carpentier

Jacob Dedel

Pieter Dirickx

't marck van ${ }^{2}$ Jan Braa, cappitien

Thijs Cornelis Vleijshouwer, secrs.

1 Lees „overgegeven".

2 Hier stond een merk in den vorm van een kruis. 


\section{Bijlage XII.}

Rijksarchief.

Overgecomen brieven en

papieren in 1620 .

Boek II, fol. 110 en 134 .

Notitie van 't gene tot Jacatra in den oorloge tot fortificatie in de Punten als andersints tot defencie geconsumeert is, te weten :

160 patcherij balatins in 2 pacgens $n^{\circ} 191$, 192, à 159 f., 16 st. yder . . . . . . f 319.12

40 halve vaten boscruijt geduerende den oorloch verschooten . . . . . . . . - 2000.-

13680 stucx grove tapes in 57 pacgens à $70 \mathrm{R} .^{1}$ ijder pack . . . . . . . . . . - 9576.-

960 stucx Guinees linnen in 48 packen à $5 \mathrm{R}$. 't stuck . . . . . . . . . . - 11520.-

71 stucx Hollants linnen tot sacken in de puncten verbesigt yder 30 ellen lanck à 6 gl. 't stuck . . . . . . . . . . . 426. 0

183 stucx kennippe lijwaten tot cardouse als andersints . . . . . . . . . . - 219.12

$1 \frac{1}{3}$ bael canefas tot blinde tenten als om de puncten te decken a. . . . . . . . - 240.-

80 stucx seyldoeck geconsumeert als voore à. R. $\frac{1}{2}$. . . . . . . . . . . . - 96.-

207 stucx ditto a $1 \frac{1}{2}$ R. 't stuck gebruyckt als voore. . . . . . . . . . - 745. 4

34 stucx armosijn tot vlaggen ende vaendels - 153. 4

9 stucx betilles tot $d^{0}$ vlaggen. . . . . - 43. 4

1844 realen van achten voor arbeijtsloon in 't fortificeeren als andersints betaalt . . - 4425.12

$6 \frac{5}{12}$ cassen londt . . . . . . . . . . . - 184.18

5 pacgens cattoene gaeren tot lonten verbesicht à $75 \mathrm{gl}$. 't pack. . . . . . . - 375.3000 plancken tot becledinghe van de puncten West Frieslant, Hollant ende Gelderlant ${ }^{2}$ als

11 Reaal $=2$ gulden 8 stuivers $=$ f 2.8.

2 Zoo werden deze punten 12 Maart 1619 genoemd. 
andersints tot beddingh verbesicht à 18 stuyvers 't stuck . . . . . . . . . f 2700 .-

55 groote dicke masten van $8,10,12,16$ vaem à 5 R. 't stuck . . . . . . . . . - 660.-

200 swalpen in de puncten tot beddingh als andersints à $1 \frac{1}{2}$ R. 't stuck . . . . . . 720.-

5 grove touwen in de puncten verbesicht à f 450 yder . . . . . . . . . . 2250.2040 stucx tapechindes in 5 pacgens, te weten: 1560 à 4 asta in 3 pacgens namentlijck:

$$
\left.\begin{array}{r}
n^{0} 222-460 \\
181-500 \\
79-600
\end{array}\right\} \begin{aligned}
1560 \text { stucx à R. } 15 \\
\text { de corge }^{1} \text { f } 2808
\end{aligned}
$$

480 à 5 asta in 2 pacgens, te weten

$$
\left.\left.\begin{array}{r}
n^{\circ} 158-240 \\
244-240
\end{array}\right\} \begin{array}{r}
480 \text { stucx à R. } 30 \\
\text { de corge f } 1728
\end{array}\right\}
$$

400 stucx cangans in 8 pacgens à R. 20 de corge - 960.-

5600 stucx caingh goelongs in 35 packgens a 300 gl. yder pack.

$$
\frac{-10500 .-}{\text { gl. } 52650.6}
$$

Item notitie van 't gene de rieden huijsen binnen 't fordt gecost hebben, die genootsaeckt sijn geweest afte te breeck om voor brandt bevrijt te sijn.

11760 bamboesen à $2 \frac{1}{2} \mathrm{R}$. 't hondert . . . . . R. $293 \frac{3}{4}$

3640 houte paelen à $4 \mathrm{R}$. ' $t$ hondert . . . . . , 146.-

3037 dagen arbeytsloon aen diverse Javanen bet $^{\mathrm{d}}$ a $\frac{1}{2}$ R. daghs. . . . . \1518 $\frac{1}{2}$

14700 atap à $\frac{1}{2} R$. 't hondert , $73 \frac{1}{2}$

R. $2031 \frac{3}{4}$ f $4876 \quad 4$

400 swalpen tot gordinghe aen de gardijns ende de puncten verbesicht à $1 \frac{1}{2}$ R. . . . 1440.300 plancken tot de 2 galderije om langs oude

11 corge $=20$ stuks. 
huijs te flancqueeren à $1 \mathrm{gl}$. 't stuck

50 swalpen tot d' galderije à $1 \frac{1}{2}$ reael

't stuck

$\left.\begin{array}{l}\text { R. } 300 \\ \text { R. } 180\end{array}\right\}$ f $480 .-$

Tot de cat verbesicht ruijm 8000 sacgens

calck à 8 sackgens per R. . . . . . . - 2400.-

10000 rooden steen à $40 \mathrm{R}$. de 10000 . . . . - 96.-

Voor loon van sandt ende coraelsteen by

de Chinesen gehaelt 500 R. . . . . . - 1200.-

Somma f 63142.10

Somma 63142.10 .

Notitie van 't gene soo aen den Coninck van Bantam en Jacatra verschoncken als bij d'Engelse gedurende den oorloch genooten is: te weeten:

aen den Coninck van Jacatra op beloofte van stilstandt van wapenen :

$\left.\begin{array}{r}5040 \mathrm{R} \text {. in contant } 2 \text { pacgens goelongs à } 40 \mathrm{R} \text {. de corge. } \\ 2 \text { - } 2304\end{array}\right\}$ f 14400 .

1309 stucx caing goelongs, te weten :

640 aen den Coninck van Bantam.

320 aen den jongen Coninck.

160 aen den Pangoran Tomagon.

189 aen diverse orang caijs van Bantam.

1309 à R. 2 't stuck . . . . . . . . . . . f 6283.4

37 stucx tapechindes aen den Coninck van Jacatra, Pangoran Padigaram ende den Tomagon van Bantam. - 116.8

61 stucx Bengaelse cleeden aan de voors. ende andre orang caijs van Jacatra ende Bantam vereert à 2 R. 't stuck . . . . . . . . . . . . . . . . . . . . 292.16

3 roers, 1 gegraveert, aen den jongen Coninck van Bantam ende 2 slechte aen sijn orang caijs . . . - 51.-

9 ellen root schaerlaecken aen den Tomagon van Jacatra de sabander Lackmoij ende andre vereert à 12 gl. d'el . . . . . . . . . . . . . . . . . 108.-

diversche Jappons lackwerck aen den ouden ende jonghen Coninck van Bantam . . . . . . . . - 528.-

Item aen contant aen graeftken R. 50. . . . . - 120.-

5 cassen bengalla aen den Coninck van Bantam ende andre vereert à $8 \mathrm{R}$. 't stuck . . . . . . . -

Dl. 73. 
Item $\mathrm{S}^{r}$ Pieter van den Broecke (om met den Coninck van Jacatra te spreecken ende aen den selven te vereeren) medegenomen dat hem bij de Javanen ontnomen is:

2 goude kettinghe

2 agaet ringen

2 robijn ringen . . . . . . . . . . -110.8

1 alcatyff . $60 .-$

Item 't naervolgende aen d'Engelsen admirael Thomas Dael gesonden:

1 silver schenckan. . . 44 oncen. f 126.8

1 gebrooke kelck. . . . 8 oncen. - 23.16

1 beecker. . . . . . $9 \mathrm{~d}^{\circ}$. . - 25.-

$3 \mathrm{~d}^{0}$ cleene samen. . . $13 \frac{3}{4}$ oncen. - 38.15

5 taffelberders . . . . 60 oncen. - 150.-

1 vergulde piramidale cop. 18 oncen. - 53.11

1 -vergulde schroeff . . $18 \frac{1}{2}$ oncen. - 60.2

5 vorcxkens . . . . . . . . . - 12.-

2 bancquet schalen . . $28 \frac{1}{4}$ oncen. - 76.9

1. lampet. met. een. schrtel. .. .. .. .. - 220.16

2 cocas de maldina . . . . . . . 37.12

1 groot lamphet schotel wegende . . . . . 75 R. . . - 180.-

2 sout vaten wegende. . $22 \mathrm{~K}$. . . 52.16

2 kelcken wegende . . 24 R. . . 57.12

1 lamphet sonder schotel vergult. . . . . . $24 \mathrm{R}$. .

Aan Adam Denten, Pieter Wadon ende fetor Bouton $1100 \mathrm{R}$. in Jappons silver gedaen .

Item aen de 3 gevangen Engelsen 4 rollen groff greijn à $10 \mathrm{R}$. 6 stuck sattijn à $8 \mathrm{R}$.

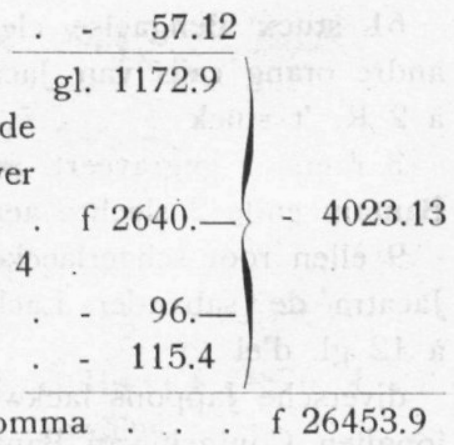


Notitie van 't gene aen ' $t$ volck van 't fordt, doense daer wt souden trecken en 't selve meende te verlaten, verstreckt ende gedaen is tot cleding als teergeldt door last van Pieter van Reij, als commandeur doen ter tijt.

150 stucx tapechindes aen de vrouwen ende kinders a $\frac{3}{4}$ R. 't stuck . . . . . . . f 270 .

120 stucx caing goelongs aen diverse vrouwen, swarten ende Chinesen wtgedeelt a 2 R'tstuck - 576.-

170 stucx cangans aen de swarten gedaen à 1 R. 't stuck . . . . . . . . . . . - 408.-

30 stucx taffacielen aen de swarte ende jongers a gl. 3 't stuck . . . . . . . . . - 90.-

280 stucx hembden ende broecken aen de soldaten ende jongers à $\frac{1}{2}$ R. . . . . . . . 336.-

$1550 \frac{1}{2}$ realen van achten aen de soldaten, borgers, timmerlieden, metselaers, swarten, jongens ende Chineesen te weten:

76 soldaten a $6 \mathrm{R}$ yder. . . . $\mathrm{R}$ 456.-

12 adelborsten a $8 \mathrm{R}$ ider . . , 96.-

5 corporaels a $10 \mathrm{R}$ ider . . " 50.-

4 sargants a 20 R. yder . . . " 80.-

50 borgers a $6 \mathrm{R}$. ider . . . . R 300.-

$\left.\begin{array}{l}2 \text { timmerluijden } \\ 4 \text { metselaers }\end{array}\right\} 8$ R. ider . , 48.-

70 swarten à $\mathrm{R} 2$ ider. . . . » 140.-

10 swarten à $4 \mathrm{R}$. ider . . . . " " 40.-

17 Chinesen a 4 R. ider . . . , 68.-

70 schooljongers a $\frac{3}{4} \mathrm{R}$ ider : . 》 $52 \frac{1}{2}$

Con stapel maijor $\left.\begin{array}{c}\text { Wolff botteliers- } \\ \text { maet. . . . }\end{array}\right\}$ à $15 \mathrm{R}$ ider» 45.de Kock . . .

Pieter Fransz. . ) $\left.\begin{array}{l}\text { Jacob de knecht } \\ \text { van Raij .... }\end{array}\right\}$ yder 10 R. » 20.-

de Cocxmaet . . . . . . " 8.-

4 timmermans jongers samen 》 8.-

D1. 73. 
Van dese naer volgende in 't wederom eijsschen te 'cort ontfangen

de luitenant . . . . R 21

de vaendrich . . . . . 12

Jan van der Dussen. . 50 R. 123.-

Witte Cornelisz. . . . 30

Melis Remmertsz. . .»10

Meester Jan betaelt . . . . » 10.-

Cornelis Jacobsz Gael voor een

podt tamerijnde. . . . , 6.-

Somma a $48 \mathrm{St}^{\mathrm{r}} \quad \mathrm{R} . \quad 1550 \frac{1}{2}$ f 3721.4

Somma gl. 5401. 4

Notitie van 't gene ten tijden, dat men in 't contract met d' Engelse stondt, bij d' een en d' ander wt het packhuijs genomen is.

1 geborduerde deecken a . . . . . . . . . f 34.19

7 stucx Pangij a 5 R. yder . . . . . . . . - 84.-

$3 \frac{1}{2}$ stucx Camelotten . . . . . . . . . . . - 229.-

6 Japponse rocken a $10 \mathrm{R}$. ider . . . . . . - 144.-

2 stucx saijen . . . . . . . . . . . . . - 23.-

74 stucx spaens leere vellen a 2 gl. 't stuck . . . - 148.-

12 stucx spaense deeckens a 3 gl. 't stuck . . . - 36.-

7 stucx lansols. . . . . . . . . . . . . - 25.4

148 stucx hembden ende broecken à $\frac{1}{2} \mathrm{R}$ t stuck. . f 177.12

$27 \frac{1}{2}$ stucx groff greijnen à $6 \mathrm{R}$ 't stuck . . . . . - 396.-

56 stucx sattijnen a 6 R. 't stuck. . . . . . . -806.8

60 stucx taffacielen a 3 gl. 't stuck . . . . . . - 180.-

47 stucx armosijnen a gl. 3 yder . . . . . . . - 141.-

Notta onder $\{126$ soo fluweele als leere ban-

't volck verdeelt $\{$ deliers f 595.5

Somma gl. 2425.3

Notitie van 't gene door den oorloge in den tuijn hebben verlaten ende bij de Javanen genomen is.

100 stucx groote hoornbeesten a $10 \mathrm{R}$

't stuck. . . . . . . . . . . R 1000.-

80 stucx bocken ende geijten a

$1^{1}$ R. 't stuck . . . . . . . . , 120.- 
Partije gansen, enden, honders ende duijven . . . . . . . . . . R 60.voor padij, dedack ende andre provisie tot onderhoudt van $d^{\circ}$ beesten. " 300.voor arbeijtsloon van eenen viver . " 100.voor een groene paggerrandt om de tuijn. , $600 .-$ voor een nieuw huys aen steen, kalck, sant, hout, riet, atap, metselen ende timmeren . . . . . . . . \$250.voor stalling van de beesten . . " 60.voor 't grooten rieden huijs. . . " 60.-

$$
\text { à } 48 \text { st. }^{\text {rs }} \text { per R. } \quad 2010 .
$$

Item exterordonnary oncosten van prauwgelden, soo hier als tot Bantam betaelt

Item een groote nieuwe galleij tot Jacatra opgemaeckt, lanck 123 voeten, leggende voor 't eijlant Onrust, opgehaelt, bij Tomas Dael in den brandt doen steecken, die ten minsten, van houdtwerck, iser als andre nootlyckheden ende arbeytsloon gecost heeft 5000 R. van achten . . . . . .

Item 't jacht de Halve Mane aen Onrust leggende om scheepen aen over te halen, door $d^{\circ}$ Engelse verbrandt, groot omtrent 60 last . . . . . .

Item 't jacht Delft, 't welck d'onse door de comste van d'Engelse genootsaeckt wierden voor Jacatra in brandt te steecken, groot ontrent 80 last.

Item 't schip den Swarten Leeuw bij Ser Tomas Dael voor Bantam in December pas ${ }^{\text {to }}$ genomen met geschut, amonitie van oorloge, seijl, treijl, touwen, anckers ende alle toebehooren soo 't wtter zee quam, groot omtrent 400 lasten.

Item een nieuw fregat, lanck 65 voeten kiels, liggende in de reviere onder 't fordt Jacatra, in den oorloge door de Javanen bij nacht wech gevoert, hebbende van materialen als arbeijtsloon ten minsten gekost.

Item een nieuwe vlott, welcke 't schip den Engel achteraen hebbende door de comste van d'Engelse voor Jacatra heeft laten drijven ende

nota.

nota.

nota. 
bij de Javanen voor de rievire van Antchol verbrant, groot 25. lasten, costende van materiallen en arbeytsloon ten minste

Item stelle tot laste van den Coninck van Bantam ende d' Engelse ontrent f 35000 , welcke de Coninck van Jacatra, diverse orang cays ende verscheyden Chinesen aen 't comptoir Jacatra schuldich waeren, die door den Pangoran van Bantam met hulpe van d'Engelse vervoert sijn

f 35000.

Item moet geconsidereert worden de extraordinarij oncosten, montcosten ende oncosten van timmeragie, dewelcke meer als de helft minder souden bedragen als nu wel doen, ende dat door de meenichte van 't volck, die alhier tegens de verraderijen van de Javanen ende Engelse tot deffentie ende bewaringhe van ons ende de Comps rijcke middelen gestadich hebben moeten houden, daer men die andersints in andre diensten souden hebben connen imploijeeren.

Item 't verleth van de reijse, die den Engel met een kappitael van f 207794-12-14 naar Suratte doen soude

Item hinder dat den handel op Jambij ende Androgirij niet hebben mogen doen, van waer ten minsten 200 lasten peper becomen hebben souden

Verhinderinge dat tijtelijck geen scheepen noch cargasoen naer Ticco, Attchin ende de cust Coromandel hebben connen seynden. . . .

Verhinderinge dat van Bantam ontrent 12000 sacgens peper min affgeset ende naer patria niet gesonden sijn dan anders gedaen souden hebben

Interest van 2251 sacgens peper in de Gouden Leeuw ende daerenboven een cargasoen sijde ende andre waere in de Sonne beloopende f 112229-7-9, die overjarich in 't lant overgebleven sijn ende met groote perijckel heen ende weder naar Amboijna geweest sijn . . . . . .

Schade de Generale Comp ${ }^{a}$ aengedaen datter 3. Chineese joncgens, die een rijck cargasoen brochten om aen ons te verhandelen, door d'Engelse

notta.

notta.

notta.

notta.

notta.

notta. 
berooft synde, alle niet min dan $100000 \mathrm{R}$ weerdich wesende.

notta.

Notitie van 't gene op 't eylandt Onrust door de subijte comste van d'Engelse hebben moeten verlaten ende door $d^{\circ}$ Engelse ende Javanen genomen, gerooft ende verbrant.

200. stucx dubbele swalpen a R. 180 't hondert R. 360.- f 864.160. stucx dicke plancken a R. 1 't stuck . " 160.- - 384.176. stucx swaere cromhouten a R. 1 't stuck " 176. - 422.8 600. stucx d $d^{\circ}$ lichte à R. $\frac{1}{2}$ 't stuck . . . \$300.- - 720.-

2. swaere balcken tot roers van scheepen à 15 R. 't stuck . . . . . . . . , 30.- - 72.-

1. nieuw roer voor 't schip Delft . . . , 40.- - 96.-

1. nieuwe boot, staende op ' $t$ landt . . 50. - 120.-

1. nieuwe maerse voor de groote mast van Delft. . . . . . . . \$ 30. - 72 -

2. draijbancken met een groot radt voor de blockmaeckers . . . . . . . . \$ 30.- - 72.-

6. groot jijnblocx met copere schijven ., 60.- = 144.200. gemeyne blocx . . . . . . . . 50._ - 120.-

50. beslage juffers . . . . . . . . . , 20.- - 48.300. pagger houten a R. 5 't hondert . . 15.- - 36.-

3. nieuwe affuijten tot dobbele saeckers ., $30 .-72$ 20. roopaerde tot stucken al beslagen . . 100._- 240.-

8. stucken geschut te weten:
6 . halve saeckers a 2200 t'samen $\$ 13200$ a 10 gl. 't
2. stucken yder hondert 1400 . . 2800 . $666 . \frac{2}{3}-1600$.

25 . anckers te weeten:

6. $\mathrm{d}^{\circ}$ ider 3600

te samen . . $\$ 21600$

10. $\mathrm{d}^{\circ}$ ider 2500

te samen . . $\gg 25000$

9. $\mathrm{d}^{\circ}$ ider 1300

te samen. . $\$ 11700$

\$58300 a 5 R. 'thondert 》2915.—-6996.-

100. picol arpuijs à R. 1 't picol . . . . , 100.—- 240.300. manden houtcoolen à R. $\frac{1}{4}$ yder . . " 75.- - 180.- 
16. lasten smeecoolen. . . . . . . . R

300. bos rottangh à 10 bos per R. . . . » 30.— - 72.-

50. sacgens calck 'à' 8 per reael . . . . " $6 \frac{1}{4}$. - 15.-

30 . bossen groote rottangh tot hoepen a 2

perR. . . . . . . . . . . . 15.- - 36.-

100. sacgens rijs a 50 R. . . . . . . . 5 50.- 120.-

30. leggers met ysere banden beslagen a

R. 7 yder . . . . . . . . . . 210.- - 504.-

190. picol Saponhoudt à 1 R. 't picol . . , 190.- 45̄6.-

300. stucx scharp van 6. 8. a $12 \mathbb{8}$. . . \ - 1

Een hospitael met 80 bedsteeden daer inne , 200_- - 480.-

32. huijsen, hebbende van bambousen, adtap

ende aerbeijtsloon gekost . . . . . 650._- 1560.-

Een saech- ende timmerhuijs . . . . 100.— - 240.-

10. huijsen daer de Chinesen woonden. . " 60.— - 144.-

102. galleij riemen à 6 gl. 't stuck . . . . . . - 612.-

21. Conincxberger plancken tot een koker van de galije - 168.-

2. dreggen tot de galleij . . . . . . . . . - 240.-

Somma f 17145.8

Laus deo adj 8 Junij anno 1619 in 't fort Jacatra.

D'Engelse Oost Indise Compa debit aen 't comp $p^{\text {tr }}$ Patanij f 152119.17.12 voor diverse goederen per $\mathrm{d}^{\mathrm{o}}$ Comp $^{\mathrm{a}}$ adij 14 December passato voor Bantam met den Swarten Leeuw genomen of 152119.17 .12 $D^{\circ}$ aen 't comptoir Jambij f $46925-10-12$ voor 1992 picol peper ende 2 picol 40 cattij drakenbloet, in Meert pas ${ }^{\text {to }}$ met 't jacht Delft door orsaecke van d' Engelse alhier voor Jacatra verbrant . . . . . . . . . . . . .

8 Julij f 6718.12 voor 117 coijangh rijs per $\mathrm{d}^{\circ}$ Engelse in Meij pas ${ }^{\text {to }}$ uyt de joncgen van Nachoda Thin Hou genomen . . . . $24 \mathrm{~d}^{\circ} \mathrm{f} 770512$ voor rijs, aracq, peper als andersints met den Swarten Leeuw als vooren per $\mathrm{d}^{\circ}$ Engelse op de reede van Bantam genomen .

\footnotetext{
1 Open gelaten.
} 
18 augustij f 10952.1 .12 aen 't comptoir Jambij voor 510 picol 75 cattij Jambische peper uijt de joncgens van Kithilij Jambij per $\mathrm{d}^{\circ}$ Engelse in de straet Palmbam gelost . . f 10952. 1.12 4 September f 52.16 voor $R 22$ aen 11 gevangen Engelse in Baetsjan in April pas ${ }^{\text {to }}$ verstreckt à R 2 yder. . . . . . . . . . 26. $d^{\circ} f 66687.6 .7$ voor diverse pertijen per $\mathrm{d}^{\circ}$ Engelse genooten, gerooft, verbrandt ende in de puncten tot borstweringe geconsumeert ende verdorven . . . . . . . . . . . - 66687. 6.7

Laus deo adij 8 July anno 1619 in 't fort Jacatra.

Moet hebben ady $\mathrm{d}^{0}$ per 't comptoir Jacatra f 1924.16 voor 10025 cattij peper per $d^{\circ}$ comptoir uijt 't verbrande jacht Delft gesalveert. f 1924.16 $d^{0}$ f 498.13 .4 voor 43 stucx besar steenen wt den swarten Leeuw per Hendrick Jansz gesalveert.

29 Augustij f 98957.10 - voor 40000 realen vanachten ende 1408 stucken loot, bij 't schip d'Engelse Sterre gevonden op $12 \mathrm{~d}^{\circ}$ in de Strate Sunda bij onse scheepen aengehaelt ${ }^{1}$.

1 Door Jaques Le Febrre werd 24 Aug. 1619 het Engelsche schip genomen, waarvoor hem 20 December als belooning een gouden ketting ter waarde van $f 600$ werd toegekend. 